د. حنان محمد فياض

\title{
أثر برنامج قائم على الوعي الصوتي في تنمية مهارات القراءة الجهرية لاى التلاميذ ضعاف السمع بالمرحلة الإبتدائية \\ إعداد
}

\section{د. حنان محمد فياض}

مدرس بقسم الصم والإعاقة السمعية ـ كلية التربية الخاصة ـ جامعة مصر للعلوم والتكنولوجيا ملخص:

استهدف البحث الحالي تحديد مدى فعالية برنامج قائم على الوعي الصوتي في

تتمية مهار ات القراعة الجهرية لدى التلاميذ ضعاف السمع بالمرحلة الابتدائية. ولتحقيق هذا الهدف تم تحديد عينة الدراسة والتى تكونت من ( • () تلاميذ من ضعاف السمعي بالصفين الثاني والثالث الابتدائي، واعتمدت الدراسة على التصميم التجريبى ذي المجمو عة الو احدة. وقامت الباحثة بإعداد وتطبيق الأدوات التالية للدر اسة:

$$
\text { - - مقياس الوعي الصوتي. }
$$

- - برنامج قائم على الوعي الصوتي لتنمية مهار ات القراءة الجهرية لاى التلاميذ

$$
\text { ضعاف السمع بالمرحلة الابتدائية. }
$$

$$
\text { وتوصلت الدراسة إلى التتائج التالية: }
$$

- يوجد فرق ذو دلالة إحصائية بين منوسطي رثب درجات مجموعة البحث على مقياس الوعي الصوتي وأبعاده في القياسين القبلي والبعدي لصالح القياس البعدي. ـ بوجد فرق ذو دلالة إحصائية بين متوسطي رثب درجات مجموعة البحث على اختبار مهار ات القراءة الجهرية في القياسين القبلي والبعدي لصالح القياس البعدي. - لا يوجد فرق ذو دلالة إحصائية بين متوسطي رتب درجات مجموعة البحث على مقياس الوعي الصوتي و أبعاده في القياسين البعدى و التتبعي. 
أثر برنامج قائم على الوعي الصوتي في تنمية مهارات القراءة الجهرية لاى التلاميذ ضعاف السمع بالمرحلة الإبتائية

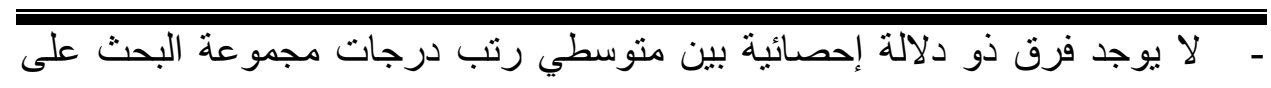
اختبار مهارات القراءة الجهرية في القياسين البعدى و التتبعي.

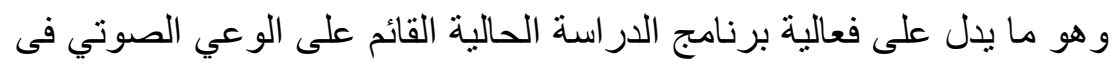

تنمية مهار ات القراءة الجهرية لدى التلاميذ ضعاف السمع بالمرحلة الابتدائية.

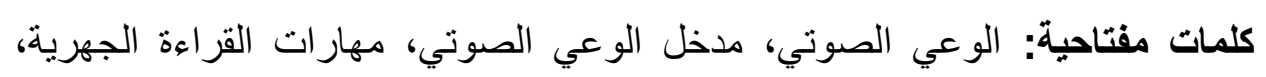

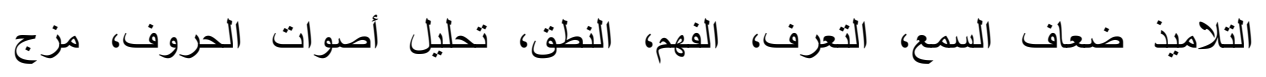

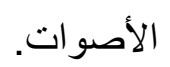




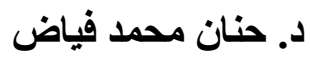

Abstract:

The Effectiveness of a Program Based on The Phonological

Awareness in Developing the Reading Aloud Skills of Primary

Stage Students with Hard of Hearing

The aim of the current study is to determine the effectiveness of a program based on the The Phonological Awareness in Developing the Reading Aloud Skills of Primary Stage Students with Hard of Hearing

The study sample consisted of (10) students with hard of hearing in the Second and Third grade of primary school. The study relied on the experimental design with one group. The researcher have used the following tools for the purpose of the study:

- Phonological Awareness Scale (Prepared by the researcher)

- The Reading Aloud Skills Test. (Prepared by the researcher)

- A Program Based on The Phonological Awareness in Developing the Reading Aloud Skills of Primary Stage Students with Hard of Hearing (Prepared by the researcher)

The results of the current study indicated that:

- There were statistically significant differences between the mean of the experimental group's scores on the Phonological awareness scale and its dimensions in the pre and post measurements in favor of the post measurement.

- There were statistically significant differences between the mean of the experimental group's scores on the

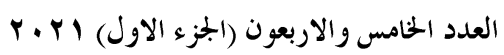

(383)

مجلة كلية التربية- جامعة عين شمس 
أثر برنامج قائم على الوعي الصوتي في تنمية مهارات القراءة الجهرية لاى التلاميذ ضعاف السمع بالمرحلة الإبتائية

Reading Aloud Skills Test in the pre and post measurements in favor of the post measurement.

- There were no statistically significant differences between the mean scores of the experimental group on the measure of phonemic awareness and its dimensions in the post and tracer measurements.

- There were no statistically significant differences between the mean scores of the experimental group on the test of reading skills in the post and tracer measurements.

This indicates the effectiveness of the current study program based on phonemic awareness in developing the skills of reading aloud among hard-of-hearing students in the primary stage.

Key words: Phonological Awareness, Phonological Awareness Approach, Reading aloud Skills, Hard of Hearing Students, Recognition, Comprehension, Pronunciation, Letter-phoneme analysis, Phoneme mixing. 
د. حنان محمد فياض

\section{أثر برنامج قائم على الوعي الصوتي في تنمية مهارات القراءة الجهرية لاى التلاميذ ضعاف السمع بالمرحلة الإبتدائية \\ إعداد \\ د. حنان محمد فياض}

مدرس بقسم الصم والإعاقة السمعية ـ كلية التربية الخاصة ـ جامعة مصر للعلوم

والتكنولوجيا

المقدمة والإحساس بالمشكلة:

إن فئة ضعاف السمع فئة مهمة ولها حق التعلم كغير ها من أبناء المجتمع، ولكن

هذا التعلم يقوم أساساً على وجود اللغة التي يفتقرون لسماع أصو اتها بدرجة أو بأخري، كنتيجة لإصابتهم وللخلل الحادث فى حاسة السمع.

ولأن لحاسة السمع تأثير ات خطيرة في اكتساب وتطور ونمو اللغة عند بداية تعلم

الأطفال لأصوات الكلام (الشخص والتهامي، 9 ـ . ץ، 9)؛ فإن الافتقار لسماع أصوات

اللغة يمثل غياباً لأحد الأعمدة الرئيسة التى يقوم عليها بناء اللغة، وسبباً رئيسًا فى الضعف فى جميع مهار ات اللغة وخاصة القراعة التى تمثل لذوي الإعاقة السمعية عامة قمة الهرم فى تلقى المعلومات و الخبرات والإطلاع على الثقافات و العلوم المختلفة. وللقراءة الجهرية أهمية كبرى للتلاميذ ذوى الإعاقة السمعية؛ إذ تسهم في النمو العام لهح من نواحي متعددة (اجتماعية، نربوية، نفسية، لغوية)، و هو ما يساعد فى تنمية مهار اتهم فى حياتهم التعليمية والاجتماعية على وجه الخصوص(الثخص والتهامي، .$(9.4 \cdot .9$

ويعد الوعي الصوتي هو أحد الأسس المهمة التى يعتمد عليها التعلم الناجح لمهار ات القراعة الجهرية، فقد أكد عديد من الباحثين على وجود علاقة ارتباطية تبادلية قوية بين الوعي الصوتي والقراءة الجهرية؛ فالوعي الصوتي يمثل قدرة سابقة على 
أثر برنامج قائم على الوعي الصوتي في تنمية مهارات القراعة الجهرية لاى التلاميذ ضعاف السمع بالمرحلة الإبتدائية

القر اهة تؤدي إلى نتائج أفضل في اكتسابها، كما تؤدى القراءة الجهرية من جهة أخرى باليه إلى تحسين وتطوير قدرات ومهار ات الوعي الصوتي.

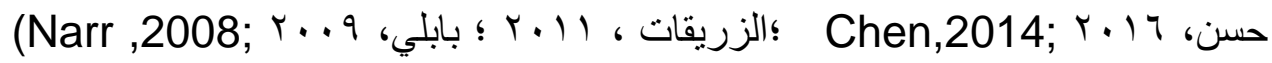
!

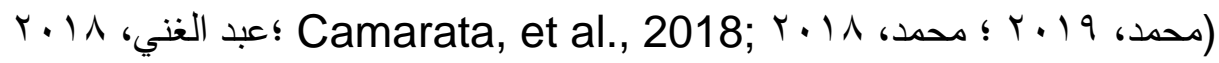

و هو ما يؤكد على ضرورة الاهتمام بتنمية مهار ات الوعي الصوتي كأساس مهر

لتنمية مهار ات القراءة الجهرية للتلاميذ ضعاف السمع فى مرحلة مبكرة من حياتهم فى في

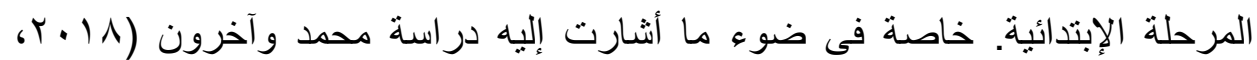

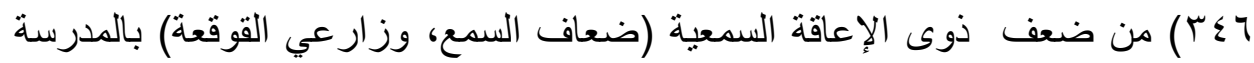
الابتدائية فى مهارات الوعي الصوتي، والذى يؤثر سلبيًا على المهارات اللغوية كالقراءة و التعرف على الكلمات المكتوبة.

و على الرغم من أهمية تتمية مهار ات القراعة الجهرية للتنلاميذ ضعاف السمع فى المرحلة الابتدائية و علاقة الوعى الصوتي الوثيقة بتحقيق هذا الهدف، فقد لاحظت الباحثة قصورًا شديدًا فى الاهتمام بهذا الموضوع، تمثل فى ندرة الدراسات و البحوث العربية " فى حدود إطلاع الباحثة" التى تعالج متغير ات هذا البحث. ولعل قصور الاهتمام أحد الأسباب التى أدت إلى ما أكدت عليه عديد من الدراسات والأطر النظرية من وجود تدنٍ شديد فى مستوى مهارات القراءة الجهرية لدى الدى التلاميذ ذوي الإعاقة السمعية بالمرحلة الابتدائية، ومعاناتهر من نقص في مهارات الوعي الصوتي، و عدم قدرتهم على تطوريها بشكل طبيعي كأقر انهم السامعين. (Narr,2008; Ambrose, 2009; Messier\& Jackson, 2013; Chen ,2014; Holmer et, al., 2016) 
د. دنان محمد فياض

و هو ما أكده كذلك عديد من الباحثين في العالم العربي، ومن ذلك:

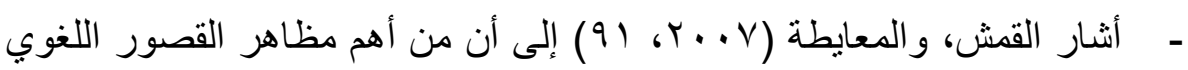

لدى الأفراد ذوي الإعاقة السمعية بالإضافة إلى الصعوبة فى اللفظ أن لغتهم

غير غنية، ومفرداتهم أقل، وجملهم أقصر، وتتصف بالتركيز على الجوانب الحسية الملموسة مقارنة بلغة السامعين، كما أن لديهم أخطاء فى الكلام و عدم

$$
\text { اتساق فى نبرات الصوت. }
$$

- أكدت نتائج دراسة حسين (10 ( ا ب) أن من أهم المشكلات التي يعاني منها

الأطفال ذوى الإعاقة السمعية ضعف مستوى القراءة.

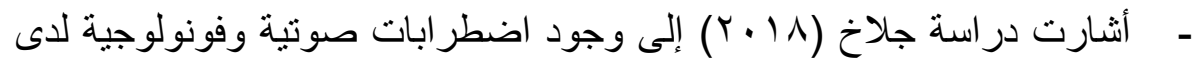
الأطفال ضعاف السمع وخاصة في بداية، ووسط، ونهاية الكلمة، والجملة؛

بالر غم من تمكن الحالة من قول الصوت صحيحًا بشكل معزول.

وقد أوصى عديد من الباحثين بالاهتمام بتنمية كل من الوعي الصوتي والقراءة

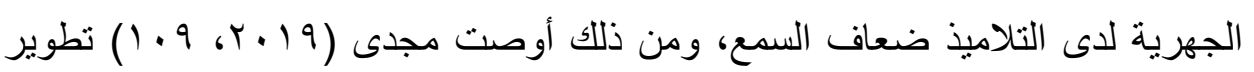
المناهج التربوية والبرامج التدريبية بحيث تركز بصورة أكبر على تدريس مهارات

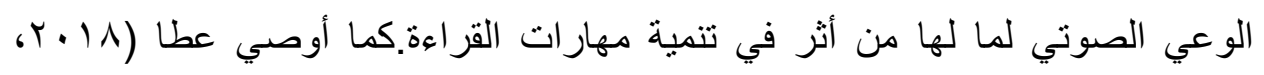
ل I T أهمية الاعتماد على مهار ات الوعي الصوتي كمدخل لتنمية المهار ات السمعية، ومهار ات اللغة من استماع وتحدث وقر اءة وكتابة للتلاميذ ضعاف السمع.وكذلك أوصي

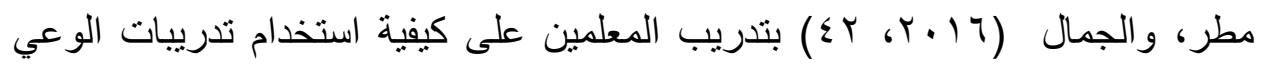
الصوتي و الفونولوجي لتحسين المهار ات اللغوية لذوى الإعاقة السمعية وبناءً على ما سبق فقد اتضحت مشكلة الدراسة الحالية فى ضعف مستوى الطلاب ضعاف السمع في مهارات القراءة الجهرية، وظهرت الحاجة لبناء برنامج تعليمي قائم على مدخل الوعي الصوتي لتنمية مهار ات القراعة الجهرية للتلاميذ ضعاف السمع بالمرحلة و هو ما دفع الباحثة إلى محاولة إجراء الدراسة الحالية.

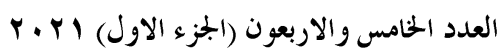

(387)

مجلة كلية التربية- جامعة عين شمس 
أثر برنامج قائم على الوعي الصوتي في تنمية مهارات القراعة الجهرية لاى التلاميذ ضعاف السمع بالمرحلة الإبتدائية

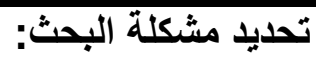

تحددت مشكلة البحث الحالي في ضعف مستوى التلاميذ ضعاف السمع بالمرحلة الابتدائية فى مهارات القراءة الجهرية، والافتقار لبرامج حديثة قائمة على الوعي الصوتي لتنمية مهارات القراعة الجهرية بما يتناسب مع خصائص واحتياجات

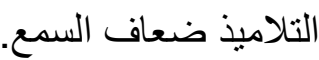
وللتصدي لهذه المشكلة تمت الإجابة عن السؤال الرئيس التالي: - ما البرنامج القائم على الوعي الصوتي لتنمية مهارات القراءة الجهرية

للتلاميذ ضعاف السمع بالمرحلة الابتدائية؟ ويتقرع عن هذا السؤال الرئيس الأسئلة الفرعية التالية:

ا - ما مهار ات القر اءة الجهرية المناسبة للتلاميذ ضعاف السمع بالمرحلة الابندائية؟ r- ما أسس ومعايير بناء برنامج قائم على مدخل الوعي الصوتي لتنمية مهار ات القراءة

الجهرية للتلاميذ ضعاف السمع بالمرحلة الابتدائية؟

r- ما برنامج تتمية مهار ات القر اعة الجهرية للتلاميذ ضعاف السمع بالمرحلة الابتدائية؟ عـ - ما فعالية البرنامج القائم على مدخل الوعي الصوتي فى تنمية مهارات القراءة

الجهرية لاى التلاميذ ضعاف السمع بالمرحلة الابتدائية؟ حدود البحث: يقتصر البحث الحالي على: - (1) 1- تلاميذ الصف الثاني والثالث الابتدائي بمدارس الأمل للتربية السمعية؛ من

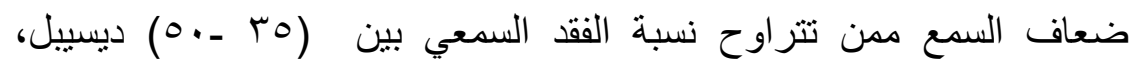
ويستخدمون معينات سمعية، و. r - ـ التلاميذ ضعاف السمع من أسر سامعين. r- التلاميذ ضعاف السمع ممن تتراوح أعمار هم الزمنية بين V- 9 سنوات. 
د. حنان محمد فياض

تحديا مصطلحات البحث:

- الوعي الصوتي: Phonological Awareness

يقصد بالوعي الصوتي في البحث الحالي، وعي التلاميذ ضعاف السمع بأن

القر اءة الجهرية

تتضمن ربط الرموز المطبوعة بالأصوات التي تقابلها، و إدراك التشابه والاختلاف

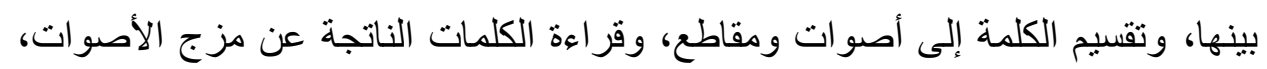
و الحكم على سجع وتقفية الكلمات، وتقسيم الجمل إلى كلمات.

\section{- البرنامج Program -}

يقصد بالبرنامج في البحث الحالي مجموعة من الخبرات والإجراءات المنظمة القائمة على مدخل الوعى الصوتي، والتي تشنمل على أهداف، ومحتوي، وأنشطة،

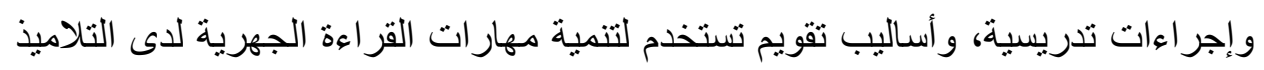
ضعاف السمع المرحلة الابتدائية. - القراعة الجهرية: Reading Aloud -

تعرف القراءة الجهرية بأنها العملية التي تترجم فيها الرموز الكتابية إلى ألفاظ منطوقة، صحيحة في مخارجها، مضبوطة في حركاتها، بأصوات مسموعة متباينة

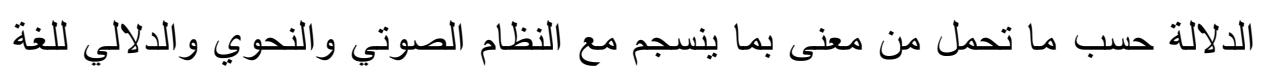

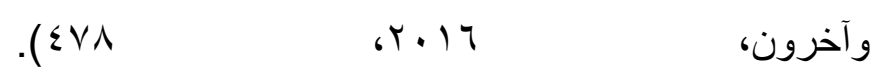

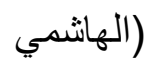

- مهارات القراعة الجهرية: Reading Aloud Skills يقصد بمهارات القراءة الجهرية في البحث الحالي مهارات: التعرف، والنطق، و الفهم. أى قدرة التلاميذ ضعاف السمع على تعرف رموز الأصوات والربط بين الصوت والرمز، ونطق الأصوات نطقاً صحيحاً من حيث المخرج والتمييز بين الأصوات المتشابهة، ونطق الحركات نطقًا صحيحًا، ونطق الكلمات و المقاطع و الجمل 
أثر برنامج قائم على الوعي الصوتي في تنمية مهارات القراعة الجهرية لاى التلاميذ ضعاف السمع بالمرحلة الإبتدائية

بطلاقة دون إبدال أو حذف أو إضافة، والقدرة على تحليل الكلمات والجمل، واستنتاج المعنى العام من السياق.

\section{- ضعاف السمع Hard of Hearing}

يقصد بهم في البحث الحالي التلاميذ الذين يعانون من قصورفي حاسة السمع يتر اوح ما بين (0 0 ـ ـ 0) ديسيبل، ويمتلكون قدرة سمعية متبقية تمكنهم عند استخدامهم

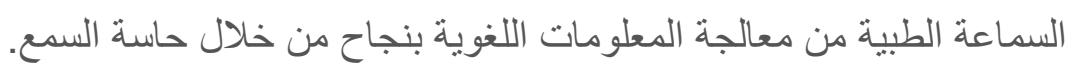

- مدخل الوعي الصوتي: Phonological Awareness Approach يقصد بمدخل الوعي الصوتي فى البحث الحالي مجموعة الأسس والمبادئ و الافتر اضات و المسلمات ذات العلاقة بطبيعة الوعي الصوتى، ومهار اته، وطبيعة تعليمه وتعلمه، والتى تتشكل في ضوئها أسس بناء برنامج- بمختلف عناصره- لتنمية مهار ات القر اءة الجهرية للتلاميذ ضعاف السمع بالمرحلة الابتدائية.

$$
\text { خطوات البحث وإجراء|ته: }
$$

سارت إجر اءات البحث وفقًا للخطوات التنالية:

1- تحديد مهارات القراءة الجهرية المناسبة للتلاميذ ضعاف السمع بالمرحلة

$$
\text { الابتدائية، وذللك من خلال: }
$$

- - دراسة خصائص التلاميذ ضعاف السمع بالمرحلة الابتدائية وحاجاتهم. - - دراسة طبيعة القراءة الجهرية، و الاحتياجات اللغوية للنلاميذ ضعاف السمع بالمرحلة الابتدائية.

- - دراسة البحوث و الدراسات التي تناولت القر اءة الجهرية للتناميذ ضعاف السمع. - - دراسة أهداف تعليم القراءة للتلاميذ ضعاف السمع بالمرحلة الابتدائية. - المقابلات الثخصية المباثرة مع المعلمين ببعض مدارس الأمل للتربية

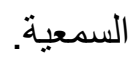




\section{د. حنان محمد فياض}

- تحديد المهارات الأكثر أهمية للتلاميذ ضعاف الصم بالصف الثالث الابتدائي، وذللك من خلال حساب الوزن النسبي لكل مهارة، واختبار أكثرالمهارات ارتفاعًا في الوزن النسبي.

r- تحديد أسس ومعايير بناء البرنامج القائم علي مدخل الوعي الصوتي لتنمية مهارات القراعة الجهرية للتلاميذ ضعاف السمع بالمرحلة الابتدائية، وذلك من

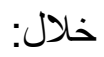

أــ مر اجعة البحوث و الدر اسات السابقة المرتبطة بموضوع البحث. - دراسة خصائص التلاميذ ضعاف السمع في المرحلة الابتدائية وحاجاتهم. - دراسة طبيعة مهار ات القراءة الجهرية وأسس تعلمها. - دراسة الأسس العامة لمدخل الوعي الصوتي.

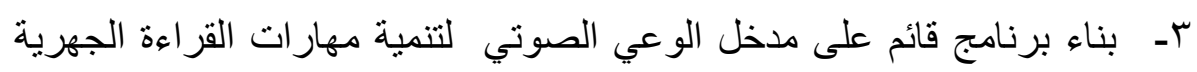

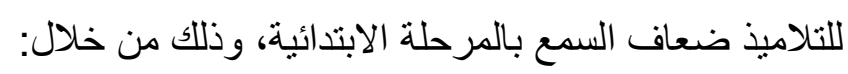

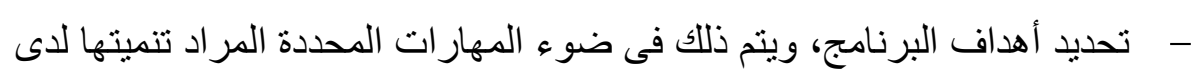
التلاميذ، وخصائص هؤ لاء التلاميذ واحتياجاتهم. - - تحديد مصادر بناء البرنامج. - - تحديد محتوى البرنامج، وتنظيمه بما يتناسب مع طبيعة التلاميذ ضعاف السمع بناء

$$
\text { وقدر اتهم. }
$$

ـ- - تحديد فاعلية البرنامج القائم على مدخل الوعي الصوني فى تنمية مهارات القراءة الجهرية المستهدف تتميتها لاى التلاميذ ضعاف السمع بالمرحلة الابتدائية، وذللك من خلال:

- - بناء اختبار في مهار ات القر اعة الجهرية المحددة، وضبطه ووضعه في صورته النهائية القابلة للنطبيق. - بناء مقياس الوعي الصوتي للتلاميذ ضعاف السمع. 
أثر برنامج قائم على الوعي الصوتي في تنمية مهارات القراعة الجهرية لاى التلاميذ ضعاف السمع بالمرحلة الإبتدائية

$$
\text { - تحديد التصميم التجريبى للبحث. }
$$

- تحديد عينة التجريب من التلاميذ ضعاف السمع بالصف الثاني والثالث

$$
\text { الابتدائي . }
$$

- تطبيق اختبار مهار ات القر اءة الجهرية، قبليًا على التلاميذ عينة البحث. - - تطبيق اختبار مقياس الوعي الصوتي، قبليًا على التلاميذ عينة البحث.

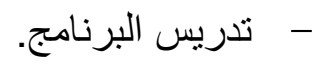

- - تطبيق اختبار مهارات القراءة الجهرية بعدياً على التلاميذ موضع البحث. - - تطبيق مقياس الوعي الصوتي بعدياً على التلاميذ موضع البحث. - رصد الدرجات ومعالجتها إحصائيًا، ورصد النتائج وتفسير ها.

$$
\text { - - مقديم التوصيات و المقترحات. }
$$

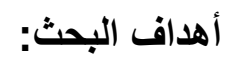

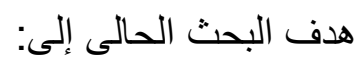

- تحديد مهارات القراءة الجهرية المناسبة للتناميذ ضعاف السمع بالمرحلة

$$
\text { الابتدائية عامة، و الصف الثاني والثالث منها خاصة. }
$$

- وضع أسس ومعايير علمية لبناء برنامج قائم على مدخل الوعي الصوتي لتنمية مهارات القراءة الجهرية للتلاميذ ضعاف السمع بالصفين الثاني والثالث الابتدائي بما يتناسب مع خصائصهم واحتياجاتهم.

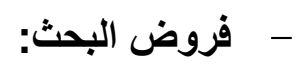

حاول البحث الحالي التحقق من صحة الفروض التالية: ا- يوجد فرق ذو دلالة إحصائية بين متوسطى رتب درجات مجموعة البحث فى

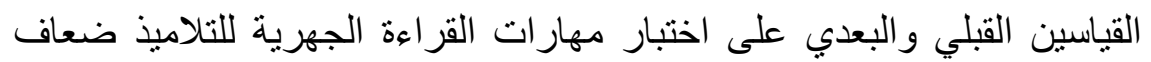

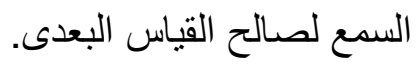




\section{د. حنان محمد فياض}

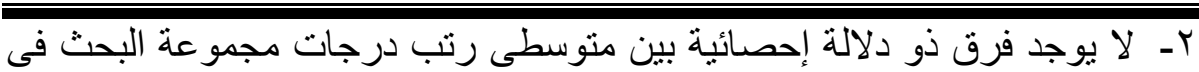
القياسين البعدي والتتبعي على اختبار مهارات القراءة الجهرية للتلاميذ ضعاف

$$
\text { السمع. }
$$

r- يوجد فرق ذو دلالة إحصائية بين منوسطى رثب درجات مجموعة البحث فى

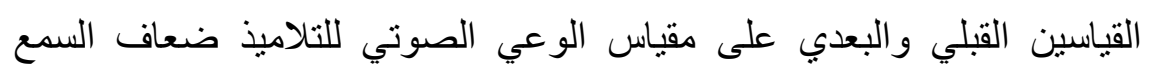

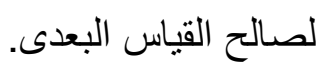
ع - ل لا يوجد فرق ذو دلالة إحصائية بين متوسطى رتب درجات مجموعة البحث فى القياسين البعدي و التتبعي على مقياس الوعي الصوتي للتلاميذ ضعاف السمع.

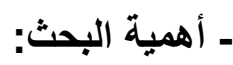
تتمثل الأهمية النظرية والتطبيقية للبحث على النحو التالي:

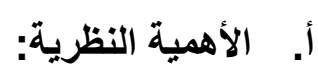
- قد تسهم هذه الدراسة في زيادة كم المعلومات والبيانات و الحقائق عن التلاميذ ضعاف السمع، وخصائصهم، وأساليب التواصل معهم، و الأساليب التعليمية المناسبة لهم. - قد تسهم هذه الدراسة في زيادة المعلومات والحقائق عن جوانب القصور في

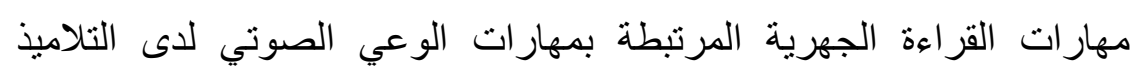
ضعاف السمع. - - إلقاء الضوء على دور مدخل الوعي الصوتي في تتمية مهارات القراءة الجهرية لدى التلاميذ ضعاف السمع.

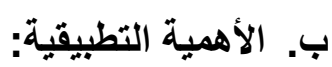
- - تقدم البحث الحالي برنامجاً لتنمية مهارات القراءة الجهرية قائم على الوعي الصوتي لاى التلاميذ ضعاف السمع (إعداد/ حنان فياض، (Y · ب). 
أثر برنامج قائم على الوعي الصوتي في تنمية مهارات القراعة الجهرية لاى التلاميذ ضعاف السمع بالمرحلة الإبتدائية

$$
\text { - إعداد مقياس الوعتبار مهار ات القراءة الجهرية للتلاميذ ضعاف السمع. }
$$

- جذب نظر مخططي المناهج للدور المهم للوعي الصوتي عند تخطبط دروس

القر اعة الجهرية للتلاميذ ضعاف السمع.

- القائمين على رعايتهم من برنامج الدراسة الحالية لتنمية مهارات القراءة الجهرية.

(الإطار النظري)

يهدف الإطار النظري إلى تحديد أسس ومعايير بناء برنامج قائم على الوعي

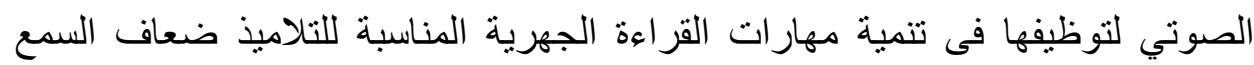
بالصف الثاني والثالث الابتدائي. وتحقيقًا لهذا الهدف يتم تتاول المحاور التالية: المحور الأول: خصائص التلاميذ ضعاف السمع بالمرحلة الإبتدائية. المحور الثاني: مهار ات القراءة الجهرية المناسبة للتنلاميذ ضعاف السمع بالصف الثاني

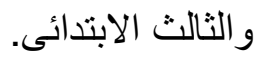
المحور الثالث: مدخل الوعي الصوتي. وتفصيل القول فى هذه المحاور كما يلي. المحور الأول: خصائص التلاميذ ضعاف السمع بالمرحلة الإبتائية: يهدف هذا المحور إلى تحديد بعض الأسس العامة الواجب مر اعاتها أثناء التدريس

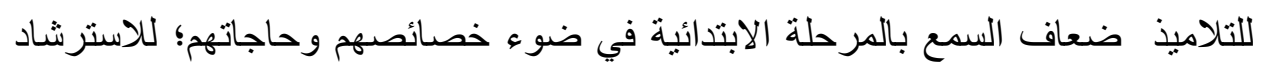

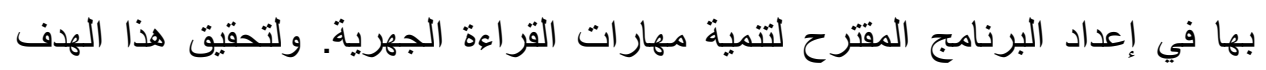
نتناول ما يلى: 


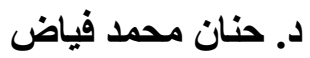

$$
\text { - - مفهوم ضعاف السمع. }
$$

- خصائص ضعاف السمع وحاجاتهم.

- الأسس العامة لتعليم التلاميذ ضعاف السمع بالمرحلة الابتدائية.

وتفصيل القول فى هذه المحاور كما يلي

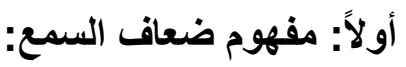

يشير ضعف السمع إلي القصور السمعي الدائم والذي يؤثر سلبياً علي المستوي

التحصيلي

للطفل. (Yssldyke; Algozzin, 2007: 384)

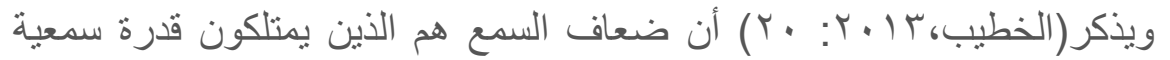

متبقية عند استخدامهم سماعة طبية تمكنهم من معالجة المعلومات اللغوية بنجاح من خلال حاسة السمع.

كما يثير ضعف السمع إلى الأشخاص الذين لديهم فقدان من بسيط إلى حاد في

حاسة السمع. و غالبية الأشخاص ذوي ضعف السمع لديهم درجات متفاوتة من الضعف، يمكن تحسينها في الغالب باستخدام سماعة لمساعدتهم على السمع. ويمكن أن يعتمدوا

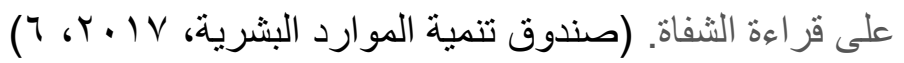
ثانياً: خصائص التلاميذ ضعاف السمع وحاجاتهز: نظرًا لأن البحث الحالي يهدف إلى بناء برنامج قائم على مدخل الوعى الصوتي

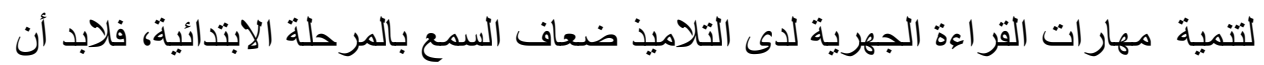
يتم هذا في ضوء در استنا لخصائصهم وحاجاتهم، وذلك كما يلى: 1ـ الخصائص والحاجات الجسمية:

لا يوجد اختلافاً جوهرياً بين النمو الجسمى للطفل ضعيف السمع وبين النمو الجسمى للطفل العادى إلا إذا كانت الإعاقة ناتجة عن الإصابة بحميات شديدة أو أمر اض فئ

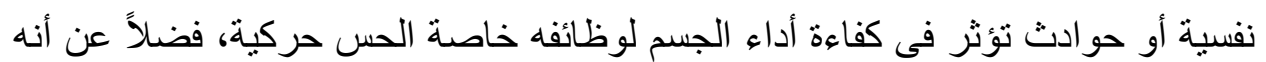


أثر برنامج قائم على الوعي الصوتي في تنمية مهارات القراعة الجهرية لاى التلاميذ ضعاف السمع بالمرحلة الإبتدائية

قد يترتب عليها شعور بالنقص و الاكتئاب والقلق ينتج عنهما اضطر ابات نفس جسمية "

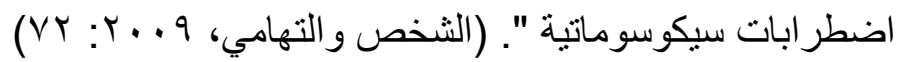

وقد أثنارت بعض الدراسات إلى وجود خصائص جسمية مميزة لضعاف السمع، منها مشكلات فى التوازن؛ والتى تعود إلي مشكلات الأذن الداخلية والإصابة بتلوث و عدوى الأذن، وانتشار الشكاوي الجسدية بينهم. كما أنهم أقل قدرة على التحكم في (Eldik, 1994, 394, Danermark, الجهاز التنفسي، وإصدار الأصوات et.al.,1996, 360)

وفي ضو ء ما سبق يمكن تحديد بعض الحاجات اللغوية لضعاف السمع منها: ـ التأكيد دومًا على وجود ارتداء التلميذ للسماعة الطبية، للاستقادة قدر الإمكان من البقايا السمعية.

ـ الاهتمام بالوسائل التعليمية البصرية في اكتساب مهار ات القر اءة الجهرية. ـ كتابة المادة العلمية للتلاميذ ضعاف السمع بخط واضح، وبنط كبير، وبألوان مناسبة بمالا برهق حاسة البصر لايهم. ـ تخصيص فتر ات راحة أثناء التدريب على الكلام و إصدار الأصوات، لتجنب إرهاق التلميذ. r- r الخصائص والحاجات اللغوية: أن مظاهر النمو اللغوي تتأثر بدرجة الإعاقة السمعية، فكلما زادت درجة الإعاقة السمعية كلما زادت المشكلات اللغوية والعكس صحيح، وبالتالي يواجه الأفراد ذوو الإعاقة السمعية البسيطة مشكلات في سماع الأصوات المنخفضة، أو البعيدة أو في فهم موضو عات الحديث المختلفة، كما يو اجهون مشكلات لغوية تبدو في صعوبة سماع وفهم ( (0\%) من المناقثات الصفية، وتكوين المفردات اللغوية، في حين يواجه الأفراد ذوو الإعاقة السمعية المتوسطة مشكلات في فهم المحادثات والمناقثات الجماعية، وتناقص هر عدد المفردات اللغوية، وصعوبة في التعبير اللغوي والكلام البطيء ويتمركز حول 


\section{د. دنان محمد فياض}

المحسوس في الكلام أكثر من المجرد، وذللك لغياب التغذية السمعية الراجعة لايه؛ مما يؤدي إلي ضعف في التواصل الاجتماعي، وكذلك انخفاض المستوي الأكاديمي وفي

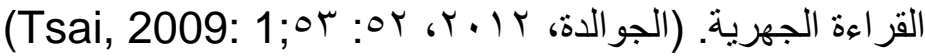
وبصورة عامة فإن ضعاف السمع يتصفون بالخصائص اللغوية التالية: - لا يستجيب التلميذ لصوت المعلم من مسافة • ا قدم أو أكثر. - يفشل في متابعة التعليمات البسيطة بطريقه مقبولة. - يصعب عليه التعبير اللفظي بحيث يكون كلامه غير واضح. - بوجه انتباهه لوجه المعلم أثناء المحادثات. - لديه ميل إلى تجنب المو اقف التي تتطلب المحادثة والاستماع. - - يخجل وينسحب من التفاعل مع التلاميذ الآخرين. - نطق الحروف بشكل غير صحيح. - - تأخر اللغة التعبيرية والاستقبالية. - معوبة المعالجة اللغوية. ـ يعبر عن السعادة إما عن طريق الضحكة الصامتةأو من خلال إحداث صرخة عالية. - يبدو حذر ا تجاه التغير ات في ديكور غرفة الصف و الأثاث و السبورة.. الخ. - يظهر ردود فعل غير عادية تجاه الأصوات العالية المزعجة مثل إغلاق الأبواب، أو

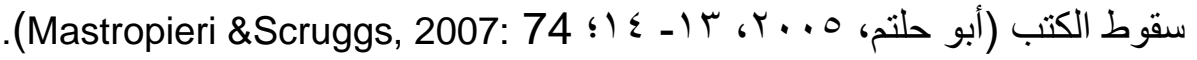
وفي ضوء ما سبق يمكن تحديد بعض الحاجات اللغوية لضعاف السمع فيما يلي: - التركيز على الكلمات المحسوسة، وبعد مرحلة من التقدم نستخدم المجردة بالتدريج. - التدرج في استخدام الجمل من البسيطة إلى المعقدة. - استخدام استر اتيجيات لتنمية الحصيلة اللغوية و النطق بطلاقة. - استخدام أساليب وفنيات علاجية تساعد في تنمية المهار ات اللغوية، مثل: النمذجة، و المحاكاة، التكرار، التعلم التعاوني، تأهيل الكلام من جديد. 
أثر برنامج قائم على الوعي الصوتي في تنمية مهارات القراعة الجهرية لاى التلاميذ ضعاف السمع بالمرحلة الإبتدائية

\section{- - ـ ـ التدريس المباشر للمشكلات اللغوية التى يو اجهها التلاميذ عينة الدراسة. r- الخصائص والحاجات الاجتماعية:}

ويرى كثير من الباحثين أنه بالكلمة المنطوقة نستطيع أن نتصل بالآخرين، وأن

$$
\text { مهارتي الحديث }
$$

و الاستماع لها أهمية خاصة في عملية الاتصال، وتتوقف عليها قدرة الفرد على التفاعل الاجنماعي، كما يتوقف عليها نجاحه في تحقيق ذاته، وإثباع كثير من حاجاته، ولكن ضعيف السمع فى كثير من الأحيان لا يستطيع سماع بعض الأصوات بوضوح؛ ويعاني من مشكلات تكيفية في نموه الاجتماعي؛ بسبب القصور الواضح في قدرته اللغوية، وصعوبة التعبير عن نفسه، وصعوبة فهمه للآخرين، سواء أكان ذلك في مجال الأسرة، أو المدرسة، أو العمل،أو المحيط الاجتماعي بشكل عام، كما ينتابه الثعور بالعزلة و الرغبة فى الانسحاب وعدم القدرة على التواصل والتفاعل الاجتماعي مع الآخرين.

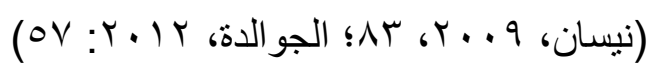
وفي ضوء ما سبق يمكن تحديد الحاجات الاجتماعية فيما يلي: - النطق الصحيح للكلمات و الجمل التى يستخدمها فى تواصله الاجتماعي مع الآخرين. - توفير خبرات كلامية ناجحة للتلاميذ ضعاف السمع. - - التعزيز المناسب لمحاو لاته فى النطق والكلام بما يشعره بتقبل الآخرين له داخل

$$
\text { الأسرة و المدرسة. }
$$

عـ الخصائص والحاجات العقلية (المعرفية):

لا تختلف القدرات العقلية لدي الطفل ذى الإعاقة السمعية والطفل السامع، وما

نر اه من انخفاض درجات ذوى الإعاقة السمعية علي مقاييس الذكاء لا يعني بالضرورة

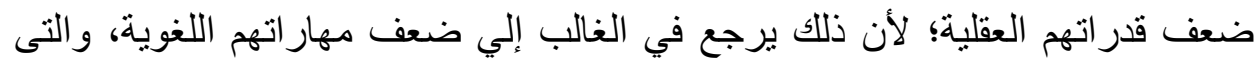
تعتمد عليها معظم مقاييس الذكاء (الجانب اللفظى)، بدليل أن أداءهم يكون مرتفعًا على بلى 
د. دنان محمد فياض

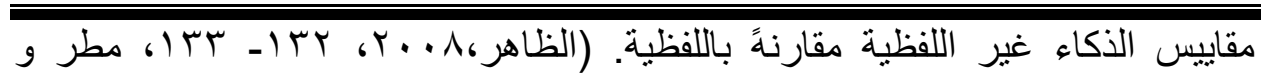

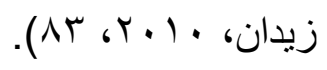

وعلى الرغم من عدم وجود فروق فى الذكاء بين ذوى الإعاقة السمعية والسامعين كما سبق، إلا أن التأثير السلبي للإعاقة السمعية على النمو اللغوي ينعكس بالسلب على بعض العمليات ذات الصلة الوثيقة بعملية التعلم. حيث يعاني غالبيتهم من

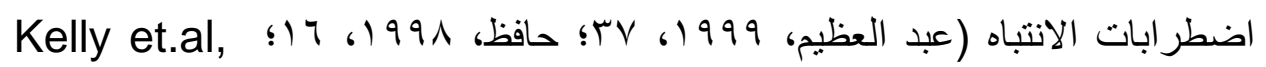
1993, 343 (1993 كما أن لديهم مشكلات فى التذكر، حيث ثبت أن مدى الذاكرة لدى ذوي الإعاقة السمعية أقصر منه لاى أقر انهم من السامعين، سواء فيما يتعلق بالوحدات اللفظية أو غير اللفظية. ويؤدي مدى الذاكرة أدوارًا مهمة في القراعة؛ حيث يساعد على دمج معاني الكلمات في الجملة، والربط بين الجمل، ولذلك فإن ضعف قدرة التلاميذ ضعاف السمع على الاحتفاظ بالمعلومات في الذاكرة قصيرة المدى بؤثز سلبيًا على مهارات Marschark,et al., 1993,31; Luckner\& McNeill, القراءة لديهج) 1994,372). وكذلك يواجه التلاميذ ذوو الإعاقة السمعية صعوبات فى اكتساب المفاهيم المتناقضة، والمتشابهة، و على الرغم من أنهم يكتسبون المفاهيم بنفس التسلسل، وبنفس الطريقة التي تتبع مع السامعين، إلا أنهم يتأخرون زمنيًا فى اكتسابها عن أقرانهم

$$
\text { السامعين (اللقانى و القرشى، } 999 \text { ( } 99 \text { ـ . (1). }
$$

$$
\text { وفي ضوء ما سبق بمكن تحديد الحاجات العقلية ـ المعرفية فيما يلي: }
$$

- تعليم التلميذ تنظيم المعرفة بالكلمة داخل الذاكرة طويلة المدى من خلال التمثيل

$$
\text { الذهني للمعلومة. }
$$

- مر اعاة الصعوبات التي تواجه التلاميذ ضعاف السمع في عمليات التذكر والانتباه. - - استخدام المثيرات والخبرات الجديدة وغير المألوفة للتلميذ بهدف جذب انتباهه واهتمامه.

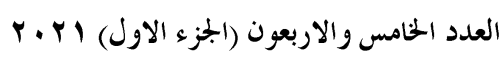

(399)

مجلة كلية التربية- جامعة عين شمس 
أثر برنامج قائم على الوعي الصوتي في تنمية مهارات القراعة الجهرية لاى التلاميذ ضعاف السمع بالمرحلة الإبتدائية

- - استخدام معينات الذاكرة مثل استر اتيجية القصة، و التنظيم، و الربط التسلسلى، الترابط الإبه الأساستى.

- - التكرار، و التدريب، باستخدام استراتيجيات مثل القراءات المتكررة، لتقوية الذاكرة

$$
\text { - }
$$

- جذب انتباه التلميذ للمثيرات المهمة - كالكلمات الجديدة - بتلوينها، أو وضع خطوط

$$
\text { تحنها. }
$$

- توفير فتر ات ر احة بين مهام التدريب مما يعمل على زيادة الانتباه. - يجب أن تتناوب المهام بين تللك التي تطلب انتباه أقل، وتللك الأكثر صعوبة. - - استخدام الوسائل التعليمية البصرية؛ إذ إنها تدعم كلًا من الذاكرة البصرية والانتباه، خاصة لاى التلاميذ ضعاف السمع بالمرحلة الابتدائية. 0ـ الخصائص والحاجات النفسية والانفعالية:

يتصف ذوو الإعاقة السمعية بصفة عامة ببعض الخصائص الانفعالية و النفسية، منها: عدم الثبات الانفعالي والاكتئاب، والميل للانطواء؛ نتيجة الثعور

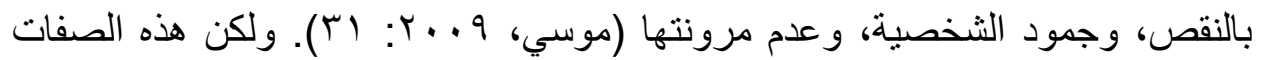
تكون لاى ضعاف السمع أقل حدة مما هي عليه لدى الصم، حتى أن نتائج بعض البحوث

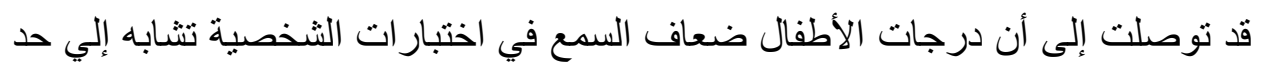

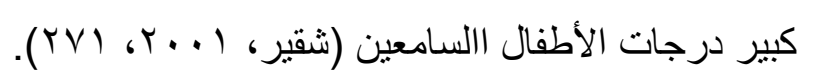
وفي ضوء ما سبق يمكن تحديد الحاجات النفسية والانفعالية فيما يلي: - إتاحة الفرصة للتنلاميذ ضعاف السمع النجاح في القراءة الجهرية، فكلما ارتفعت مستويات القر اءة الجهرية، كلما ارتفعت درجاتهم في تقدير الذات. - عدم انتقاد كلام التلميذ ضعيف السمع. 


\section{د. حنان محمد فياض}

- - توفير بيئة كلامية مريحة للتلميذ ضعيف السمع للحد من الإحباط و القلق. - التعزيز الإيجابى المنتظم على طلاقة التلميذ. -

ثالثا: الأسس العامة لتعليم التلاميذ ضعاف السمع بالمرحلة الابتدائية:

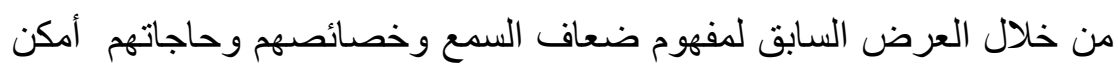
الخروج ببعض الأسس العامة لتعليمهم، و التي تتمنل فيما يلي: ـ - تشجيع استجابات التلاميذ الصحيحة وتقديم المعززات المعنوية أو المادية، ومراعاة توظيف فنّية التكر ار و التغذية الر اجعة باستمر ار معهر. - إعداد ملف لكل تلميذ، يحتوي على الاختبارات والمقاييس التي يتم تطبيقها عليه، وكذلك تقيم الأنشطة التي قام بها في كل حصة والواجبات المنزلية التي نفذها، و المعززات التي تم استخدامها معه، ومدى تقدمه خلال حصص البرنامج والملاحظات السلوكية التي أظهر ها. - مر اعاة جذب انتباه التلاميذ من خلال تنويع الأنشطة الفردية والجماعية، والصور، و البازل الخشبي، وما إلى ذلك من أنشطة محببة إلبهم. - توفير البيئة التعليمية التي تساعد ضعاف السمع على الثعور بالتقبل ممن حوله في الأسرة والمدرسة والمجتمع، وإحاطة ضعيف السمع بجو من العلاقة الدافئة مما يقوي لئي ثتها بنفسه وبالآخرين. - المساواة في التعليم بين ضعاف السمع والسامعين، وهو ما يعني وضع التدابير التعليمية التي تتيح لضعاف السمع الفرصة للتعلم، وفقاً لخصائصهم واحتياجاتهم. - استخدام مداخل وأساليب تدريس متتوعة في تعليم ضعاف السمع، و التركيز على ما يكون للتلميذ فيها دورٌ إيجابي؛ لتعويده تحمل المسئولية، وتوظيف بقايا السمع لديه. 
أثر برنامج قائم على الوعي الصوتي في تنمية مهارات القراعة الجهرية لاى التلاميذ ضعاف السمع بالمرحلة الإبتدائية

- استخدام أساليب وفنيات علاجية تساعد في تنمية المهارات اللغوية (خاصة مهارات القر اءة الجهرية)، مثل: التعلم التعاوني، المحاكاة، حل المشكلات، تأهيل الكلام من جديد. - التدريب السمعي للمحافظة على بقايا السمع لدى الأطفال ضعاف السمع وتقويتها و استغلالها. ـ التدريب على إخر اج الأصوات الهجائية من مخارجها الصحيحة باستخدام برنامج قائم على مدخل الوعي الصوتي. ـ استخدام الأجهزة التعليمية الحديثة في العملية التعليمية. - إتاحة الفرصة لضعيف السمع لتحقيق النجاح و الثعور بالأمان والثقة. ـ تشجيع التلميذ ضعيف السمع على تكوين علاقات جديدة مع جماعة من الرفاق. المحور الثاني: مهارات القراءة الجهرية المناسبة للتلاميذ ضعاف السمع بالصف

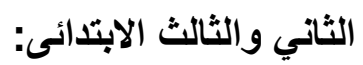
يهدف هذا المحور إلى تحديد مهار ات القراءة الجهرية المناسبة للتلاميذ ضعاف السمع بالمرحلة الابتدائية وكذللك تحديد الطر ائق و الاستراتيجيات المناسبة لتنميتها، ومن ثم تحديد بعض الأسس الواجب مراعاتها عند تعليم مهارات القراءة الجهرية للتلاميذ بلهي

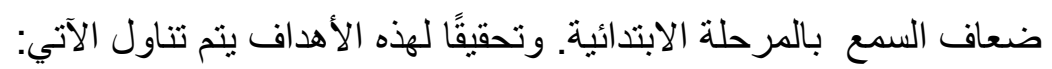

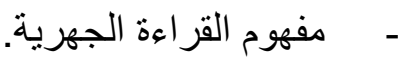
- أهمية القر اعة الجهرية. - الدر اسات السابقة التى تناولت تتمية مهار ات القراءة الجهرية لدى التلاميذ ضعاف السمع. - صعوبات (مظاهر الضعف) القراءة الجهرية للتنلاميذ ضعاف السمع في المرحلة الابتدائية.

- أهداف تعليم القراءة الجهرية للتناميذ ضعاف السمع فى المرحلة الابتدائية. - مهار ات القراءة الجهرية المناسبة للتلاميذ ضعاف السمع فى المرحلة الابتدائية. 


\section{د. حنان محمد فياض}

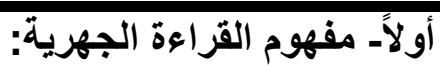

لقد حدثت تطور ات كبيرة فى مفهوم القراءة، حيث كان ضيقًا يتمثل فى الإدر اك البصرى للرموز المكتوبة والتعرف عليها والنطق بها، ثم تطور مفهوم القراءة، فأصبح يعنى التعرف على الرموز ونطقها، وترجمة هذه الرموز إلى ما تدل عليه من معاني و أفكار، ومع تزايد مشكلات الحياة أصبح مفهوم القراءة هو نطق الرموز، وفهمها، ونقدها، وتحليلها والتفاعل معها، وحدوث رد فعل بالنسبة لها مع تمكين القارئ من استخدام ما يستو عبه، وما يستخلصه فى مو اجهة مشكلات الحياة (مصطفى، . . . ب، 0؛ ).

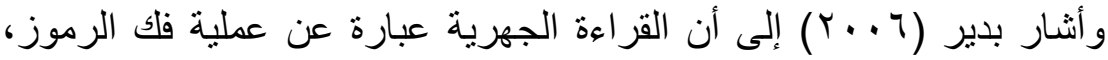
وتحويل الرموز المطبوعة إلى أصوات تمثلها لتشكل اللغة المنطوقة المسموعة.

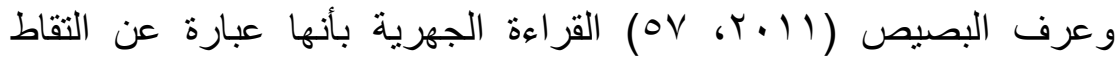
الرموز المطبوعة بالعين وترجمة المخ لها، ثم الجهر بها باستخدام أعضاء النطق استخداماً صحيحاً.

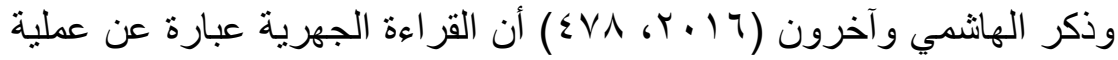
تُرجم فيها الرموز الكتابية إلى ألفاظ منطوقة، صحيحة في مخارجها، مضبوطة في حركاتها، بأصوات مسموعة متباينة الدلالة، حسب ما تحمل من معنى، بما ينسجم مع النظام الصوتي و النحوي و الدلالي للغة. وترتبط عملية القر اءة بمجموعة من العمليات العقلية المتسلسلة، وهى: ـ تركيز الانتباه على الحروف المطبوعة والتحكم في حركة العينين خلال سطور الصفحة. ـ تعرف الأصوات المرتبطة بتلك الحروف. - فهم معاني الكلمات و إعر ابها في الجملة. - بناء أفكار جديدة بالاعتماد على الأفكار التي يعرفها من قبل. 
أثر برنامج قائم على الوعي الصوتي في تنمية مهارات القراعة الجهرية لاى التلاميذ ضعاف السمع بالمرحلة الإبتدائية

ـ اختزان تلك الأفكار في الذاكرة، حيث تحتاج العمليات العقلية إلى شبكة سليمة وقوية

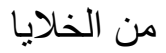
العصبية لكي تربط مر اكز البصر و اللغة والذاكرة بالمخ. وفي ضوء ما سبق يمكن تعريف القراءة الجهرية بأنها عملية عقلية يتم من خلالها ترجمة الرموز المكتوبة لمعانى مفهومة، وللغة منطوقة صحيحة.

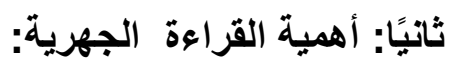

تعتبر القراءة الكيان الذي ترتكز عليه قضية التعليم والتعلم، ووسيلة الفرد للحصول على المعرفة، و لإحداث تعليم مثمر، كما أنها تساعد القارئ على توصيل محتوى المقروء للآخرين، وتفسير محتويات القطعة المقروءة، ونمو الأصوات

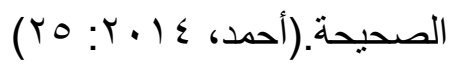
وتسهم القراءة الجهرية فى تحقيق الأهداف العامة للقراءة، فضلً عن دورها فى النمو العام للطفل في جو انب متعددة، وذلك كما يلي: تربويًا: تسهم القراءة الجهرية في: - إتقان النطق والأداء وتمثيل المعنى؛ لأن الأداء الصوتي في القراءة يتطور ويتحسن

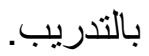

- تدريب التلميذ على صحة الأداء ومر اعاة علامات الترقيم، من فو اصل ونقط. - تحسين الطلافة والدقة في القراءة الصامتة؛ لأن تعلم القراءة الصامتة في المرحلة الابتدائية بستلزم استعمال القراءة الجهرية، لتكوين مهارات تعرف الكلمة وأصوات الحروف، و إدر الك مدلو لاتها. ـ تمكين التلميذ من التعلم الأكاديمي فى جميع المناهج الدراسية، وتتقيف نفسه وبناء شخصيته. - تتمية قدرات التلميذ الفكرية والتعبيرية. 
د. دنان محمد فياض

لغويًا: تعد القراءة الجهرية:

ـ أحد أفضل الوسائل التي ثُتبع لتشخيص مشكلات القر اءة لدى القارى؛، وملاحظة عاداته في القراءة الجهرية، فتساعد المعلم على اكتشاف أخطاء التلمبذ في النطق. - وسيلة لاتقان النطق، وإجادة الأداء والتعبير عن المعاني بنبرات صوتية مفهومة، وخاصة بالصفوف الأولى في المرحلة الابتدائية. نفسيًا: تساعد القر اءة الجهرية في: ـ تشجيع التلاميذ الذين يشعرون بالخجل، إذ تعودهم الثجاعة وتبعث في نفوسهم الثقة. ـ تتمية ميول التلميذ واهتماماته وحبه للقر اءة،و الاستفادة من أوقات الفر اغ. ـ تتمية قدر ات التلميذ على مو اجهة المو اقف، و اكتساب صفات القيادة و التوجيه. - إدخال المتعة والسرور، وغرس روح الجماعة وخاصة للتلاميذ الصغار. اجتماعيًا: تساعد القر اعة الجهرية التلميذ فى تحقيق التوافق الثخصي والاجتماعي.

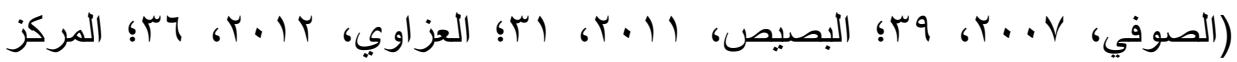

$$
\text { القومي للامتحانات و التقويم التربوي، } 0 \text { ( ـ ب، V). }
$$

ثالثًا: الدراسات السابقة التى تتاولت تمية مهارات القراعة الجهرية لاى التلاميذ

ضعاف السمع:

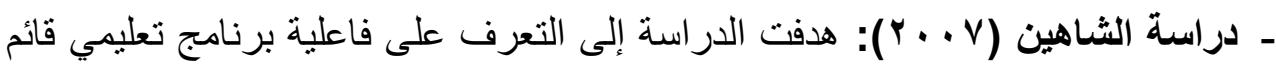
على التعلم الفردي في تحسين مهار ات القراءة لدى ( • ب) من الطلاب ضعاف السمع بالمرحلة الابتدائية في مدينة دمثق، تم تقسيمهم لمجموعتين إحداهما تجريبية و الأخرى ضابطة، وطُبِق عليهم : برنامج القراءة المستند إلى أسلوب التعليم الفردى، واختبار للقراءة (إعداد/ الباحث). وأشارت النتائج إلى فاعلية البرنامج المقترح في

تحسين مهار ات القراعة للطلاب ضعاف السمع.

- دراسة Stephanie (2008): هدفت الدراسة إلى القيام بعمل مسح لصعوبات القر اعة لدى الطلبة ذوى الإعاقة السمعية، وتكونت عينة الدر اسة من ( . . . 9) فرد من بين طلبة، ومعلمين، ومديرين، وآخرين من الأفراد المشاركين في تعليم الطلبة ذوي

$$
\begin{aligned}
& \text { العدد الخامس والاربعون (الجزء الاول) I. Y. }
\end{aligned}
$$

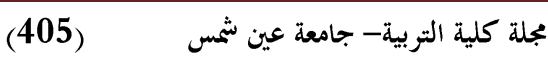


أثر برنامج قائم على الوعي الصوتي في تنمية مهارات القراعة الجهرية لاى التلاميذ ضعاف السمع بالمرحلة الإبتدائية

الإعاقة السمعية. وقد توصلت نتائج الدراسة إلى أن الطلبة ذوي الإعاقة السمعية يعانون من مشكلات واضحة في المهارات القرائية المرتبطة بالتمييز السمعي، و التحليل الصوتي و الاستيعاب.

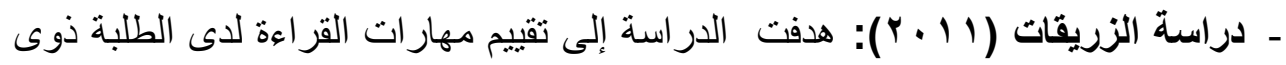
الإعاقة السمعية وعلاقتها ببعض المتغيرات ذات الصلة، وقد اشتملت عينة الدراسة على (Tr I ) طالبًا وطالبة من الملتحقين بمدارس الصم في الأردن فى الصفوف من الرابع للسادس الابتدائي، وطبق الباحث عليهم اختبار مهارات القراءة (من إعداده). و أوضحت النتائج أن الطلاب ذوى الإعاقة السمعية يمتلكون فى المجمل مهارات قراءة ضعيفة، وأن أداء الإناث على بعدي المفردات والفهم كان أفضل من الذكور. كما أنشارت البيانات إلى أن طلبة الصف الرابع يمتلكون مهارات طلاقة ومهارات الإدراك و الوعي الصوتي أفضل من طلبة الصف السادس. وأن طلبة الصف الخامس أفضل فى مهارات الإدراك والوعي الصوتي من طلبة الصف السادس كما أظهرت النتائج أن مهار ات الطلاقة أفضل لدى ذوى الفقد السمعي المتوسط منها لدى ذوى الفقد السمعي الثديد والعميق، وأن الطلبة الذين يستخدمون التواصل الكلي يمتلكون مهارات القر اعة أفضل من الطلبة الذين يستخدمون طريقة لغة الاشارة. كما أظهرت النتائج أن الطلبة الذين يستعملون السماعة الطبية لديهم مهارات الطلاقة والتمييز البصري

و الإدراك و الوعي الصوتي أفضل من الطلبة الذين لا يستعملون السماعة الطبية. - دراسة خولة (1 (1) ب): هدفت الدراسة إلى تحديد مدى فاعلية برنامج تدريبي محوسب لتعليم مهار ات القراءة بطريقة التواصل الكلي والطريقة الثفوية لأطفال الروضة ذوى إلى الإعاقة السمعية. وقد بلغ عدد أفراد الدراسة ( • ب) طفلًا، تم تقسيمها لأربع مجمو عات: مجموعتان تجريبيتان تم التدريس لإحداهما بطريقة التواصل الكلي المحوسبة، وتم التدريس للأخرى وفق الطريقة الثفوية المحوسبة، ومجموعتان ضابطتان نم التدريس 
د. دنان محمد فياض

لهما بالطريقة التقليدية. وقد أشارت النتائج إلى وجود فروق ذات دلالة إحصائية لصالح المحموعتين التجرييتين مقارنة بالمجموعتين الضابطتين، كما أنشارت النتائج إلى أن طريقة التواصل الكلى المحوسبة أكثر فعالية من الطريقة الثنفوية المحوسبة. - دراسة عبد الأحمد (Y Y Y Y): هدفت الدراسة إلى التعرف على أثر برنامج تعليمي مستتد إلى الطريقة السمعية- اللفظية في تتمية المهارات القرائية لدى التلاميذ ضعاف

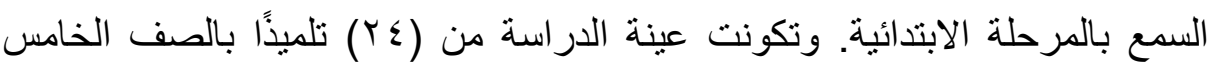

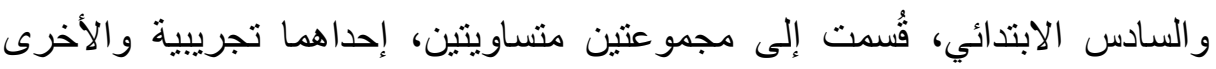
وضابطة. وقام الباحث بإعداد أدوات الدراسة، وهى: قائمة مهارات الاستيعاب السمعي، قائمة المهارات القرائية، برنامج لغوي مستتد على الطريقة السمعية ـ اللفظية؛ لتنمية مهارات الاستيعاب السمعية والمهارات القرائية لدى التلاميذ عينة الدراسة، اختبار مهارات الاستيعاب السمعي، اختبار المهارات القرائية. وبتطبيق البرنامج والاختبارات أنشارت النتائج إلى جود فروق دالة إحصائياً في مهارات الاستيعاب السمعي ومهارات القراءة لصالح المجموعة التجريبية، تعزي إلى البرنامج

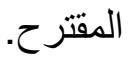

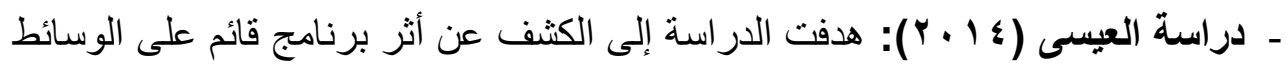
المتعددة في تتمية مهارة القراعة الجهرية لدى التلاميذ ضعاف السمع فى مدارس الدمج بالمرحلة الابندائية. وتكونت عينة الدراسة من مجموعتين إحداهما التجريبية (عاهية تلاميذ) ومجموعة ضابطة ( ع تلاميذ) وقد تحددت المهارات المستهدفة في أربع مهار ات هي: (مهارة القراءة الصحيحة للكلمات ـ مهارة القراعة بطلاقة ويسر مهارة الضبط النحوي للنص المقروء ـ مهارة تلوين الأداء القرائي حسب السياق)، وقام الباحث بإعداد أدوات الدراسة، وهى: بطاقة ملاحظة واختبار تتخيصي لقياس مهارات القراءة الجهرية، وبرنامج قائم على الوسائط لتنمية مهارات القراءة 
أثر برنامج قائم على الوعي الصوتي في تنمية مهارات القراعة الجهرية لاى التلاميذ ضعاف السمع بالمرحلة الإبتدائية

المستهدفة. وأسفرت نتائج الدراسة عن فعالية برنامج الوسائط المتعددة فى تنمية مهار ات القر اعة الجهرية المستهدفة للتلاميذ ضعاف السمع.

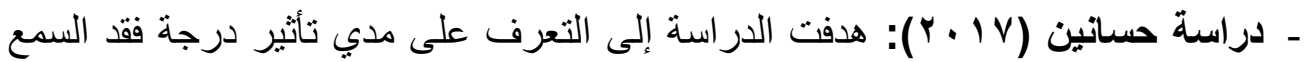
بمستوياتها (الصمم- ضعاف السمع) على أداء التلميذات في مهارة القراءة الجهرية و الصامتة، وتكونت عينة الدراسة من (• (7) من التلميذات ذوات الإعاقة السمعية، ويتر اوح العمر الزمني (• ( - Y I) عامًا، وقد أشارت نتائج الدراسة إلى وجود ارتفاع مستوي أداء التلميذات ضعاف السمع في القراءة بنو عيها (الجهرية والصامتة) وزيادة أخطاء القر اءة لدي التلميذات الصم.

- دراسة . Wang, et al. القرائى، وبعض العوامل وهى: التعرف علي الصوت، الدقة في القراءة الصامتة، الوعي المورفولوجي. وتكونت عينة الدر اسة من (0؛ ) طفل من ذوي الإعاقة السمعية ممن تتر اوح أعمار هم الزمنية من (^- ـ ( ) سنة. واستخدمت الدراسة الأدوات التالية: - اختبار الدقة قي القراءة الصامتة للكلمة Test of Sielent Word Reading Fluency (TSWRF) (TSWRF; Mather et al., 2004) - اختبار الفهم القرائي للفقرة لوودكوك جونسون The Passage Comprehension

Subtest of Woodcook Johnson III (WJ- III) ( Woodcock et al., 2001) وأنشارت نتائج الدراسة إلي أن الفهم الأفضل للمهارات اللغوية كالتعرف على الأصوات، والدقة فى القراءة الصامتة يُعد ضروريًا لتحسين الفهم القرائي. كما أثشارت النتائج إلي ضرورة التركيز علي أساسيات علم الصوتيات و الذي يشمل علي قدرة المتعلم علي مزج وفصل الأصوات مما له أثر في تحسين الفهم القرائي للأطفال ذوي الإعاقة السمعية. 


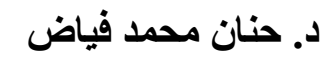

\section{وقدا أفادت الاراسة الحالية من الاراسات السابقة فى هذا المحور فهما يلي:}

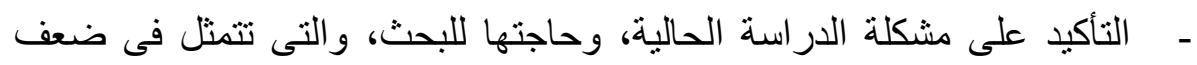

التلاميذ ضعاف السمع فى مهارات القراءة عامة، ومهار ات القراءة الجهرية

على وجه الخصوص، كما فى دراسة (2008 ) Stephanie، ودراسة

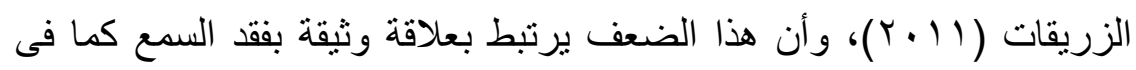

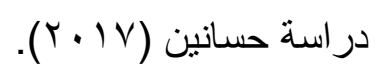

- الاستفادة مما تضمنته هذه الدراسات السابقة من بر امج تعليمية لتنمية مهارات

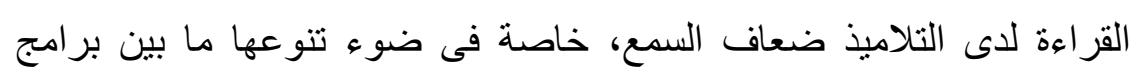

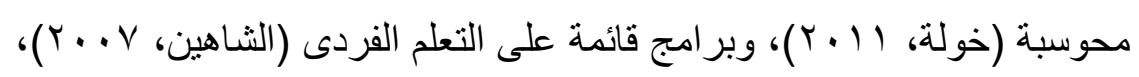

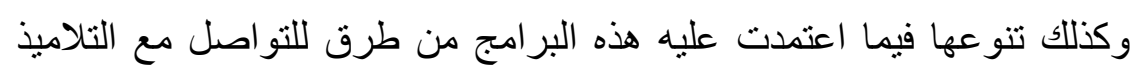

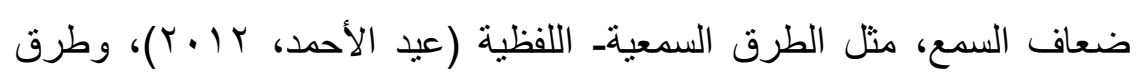

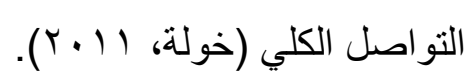

- - تحديد بعض العوامل المؤثرة فى القراءة لدى التلاميذ ضعاف السمع لمر اعاتها

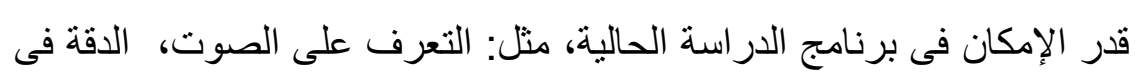

$$
\text { القر اءة الصامتة، الوعي الفونولوجي. }
$$

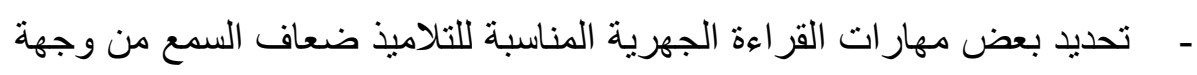
نظر بعض الدراسات السابقة، مثل: القراءة الصحيحة للكلمات، مهارة القراءة

$$
\text { بطلاقة ويسر ، مهارة تلوين الأداء القرائى. }
$$

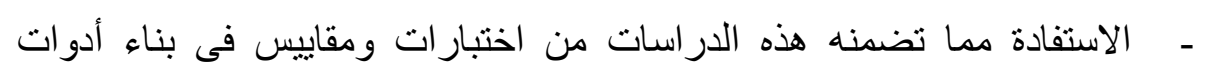
الدر اسة الحالية، كاختبار القراءة الجهرية، ومقياس الوعي الصوتي. 
أثر برنامج قائم على الوعي الصوتي في تنمية مهارات القراعة الجهرية لاى التلاميذ ضعاف السمع بالمرحلة الإبتدائية

رابعًا: صعوبات (مظاهر الضعف) القراعة الجهرية للتلاميذ ضعاف السمع في المرحلة

الابتدائية:

تشمل المرحلة الابتدائية بمدارس الأمل ثماني سنوات دراسية. ويبدأ التلاميذ

ضعاف السمع فى تعلم القراءة الجهرية منذ الصف الأول الابتدائى، باستخدام نفس لهن المناهج الدراسية المقررة على التلاميذ السامعين، ولكن مع اختلاف نوزيع موضوعات الكتب الدراسية على الصفوف الدراسية، وهى مناهج لا نتناسب مع خصائص واحتياجات التلاميذ ضعاف السمع بالمرحلة الابتدائية.

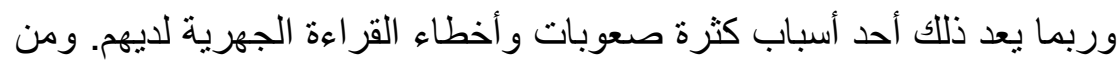
خلال دراسة عديد من الأدبيات السابقة أمكن تحديد بعض أخطاء وصعوبات القراءة الجهرية التي يعانى منها التلاميذ ضعاف السمع بالمرحلة الابتدائية فيما يلى: ـ تعرف أصوات الحروف الهجائية. ـ الخلط بين الحروف المتشابهة، مثل: ب- ثـ ته، ج- ح- خ إلخ. ـ التونر الانفعالى أثناء القراءة الجهرية. - عدم تناسب المدى البصري مع الصوتي. - عدم القدرة على تجزئة المقروء إلى عبار ات ذات معنى. - بطء شديد وو اضح في سر عة التعرف على الكلمة. المعرفة المحدودة لمعاني الكلمات. عدم القدرة على ضبط معدل السرعة. - 2 - مدم فهم الجملة.

ـ المبالغة في رفع الصوت أو خفضه أثناء القراءة الجهرية. ـ الإدخال، بأن يدخل التلميذ كلمة فى السياق ليست موجودة فيه أصلاً. 


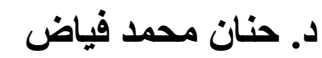

ـ التكرار، و هو أن يكرر التلميذ حرفاً، أو مقطعاً من كلمة، أو كلمة بكاملها من الجملة أو الفقرة، أو تكرار الجملة باكملها. ـ الحذف أن يحذف التلميذ حرفاً أو أكثر، أو مقطعاً من كلمة، أو كلمة بكاملها من الجملة أو الفقرة. ـ الإبدال من خلال القيام باستبدال حرف أو أكثر. ـ القلب المكاني، وذللك بوضع حرف مكان حرف مثل (نمو) بدلاً من (نوم).

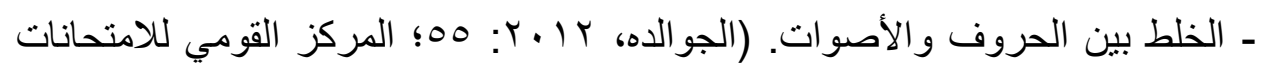

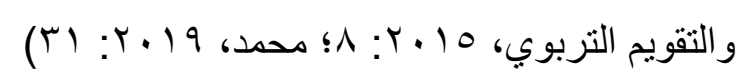
وتري الباحثة أنه من الضروري تصميم برنامج تعليمي للقراءة الجهرية

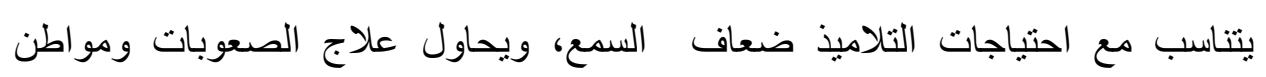
الضعف السابقة.

خامسًا:أهداف تعليم القراعة الجهرية للتلاميذ ضعاف السمع فى المرحلة الابتدائية: من خلال دراسة أهداف وحدات ودروس كتب اللغة العربية المقررة على التلاميذ

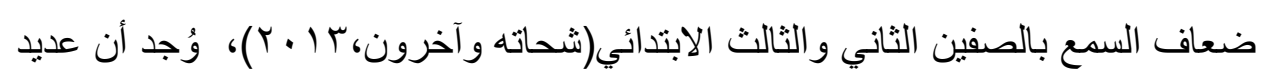
من هذه الأهداف يتعلق بالقر اعة الجهرية، مثل: - أن يدمج التلميذ بعض الأصوات ويكون منها كلمات. ـ أن يميز التلميذ الأصوات في أول الكلمات وفي آخر ها. ـ أن يميز التلميذ بين الأصوات المتقاربة. ـ أن ينطق التلميذ كلمات ذات معنى. - أن يقر أ التلميذ الدرس قراءة جهرية معبرة. ـ أن يميز التلميذ بين الأصوات المتقاربة. - أن يسرد التلميذ حكاية موجزة. ـ أن يصل التلميذ الجملة بالصورة الدالة عليها. 
أثر برنامج قائم على الوعي الصوتي في تنمية مهارات القراعة الجهرية لاى التلاميذ ضعاف السمع بالمرحلة الإبتدائية

$$
\begin{aligned}
& \text { ـ أن يأتي التلميذ بكلمات على وزن واحد. } \\
& \text { ـ أن يميز التلميذ بين أنواع المد. } \\
& \text { ـ أن يجيب التلميذ عن أسئلة حول النص المقروء. } \\
& \text { ـ أن يتعرف التلميذ على مفردات جديدة. }
\end{aligned}
$$

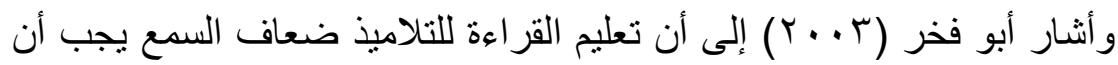

يركز على مجموعة من الأهداف الأساسية، وهى: تنمية الإدراك البصري لتشكيل المفردات، تنمية القدرة على التعرف على الكلمات، وتطوير عادة قراءة فقرة معينة واستيعابها، تنمية قدرة التلميذ على تذكر شكل المادة المكتوبة. (أبو فخر، ؟ . . ץ). وتحديد أهداف تعليم القراءة للتلاميذ ضعاف السمع سيسهم فى تحديد بعض مهار ات

القر اءة الجهرية المناسبة لهم، تلك المهار ات التى سيتم تناولها بالتفصيل فيما يلي. سادسًا: مهارات القراعة الجهرية المناسبة للتلاميذ ضعاف السمع فى المرحلة الابتدائية:

من خلال دراسة كتابات عديد من الباحثين بشأن مهارات القراءة الجهرية المناسبة لتلاميذ المرحلة الابتدائية عامة والتلاميذ ضعاف السمع خاصة (عزازى،

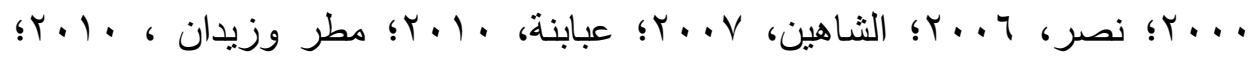

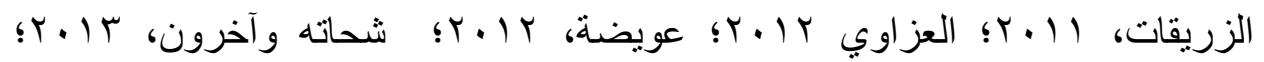

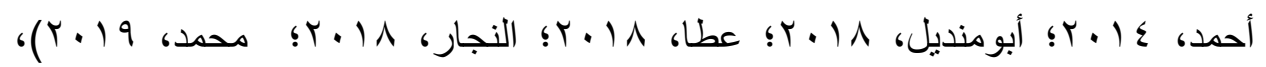
وبمر اعاة أهداف تعليم القر اهة وصعوباتها لدى التلاميذ ضعاف السمع ـ كما سبقـ أمكن تحديد عدد من مهارات القراءة الجهرية المناسبة للنلاميذ ضعاف السمع بالصفين الثاني

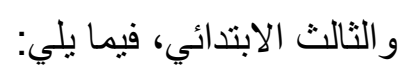
ـ مهارة التعرف: ويُقصد بها التعرف على رموز الأصوات، والربط بين الصوت و الرمز، من خلال توظيف مهارني التمييز السمعي والبصري، ومهارة الذاكرة؛ للربط 


\section{د. حنان محمد فياض}

بين المعطيات البصرية والسمعية ، والتعرف على الأصوات و المقاطع و الكلمات و الجمل. وتتضمن مهارة التعرف المهار ات الفرعية التالية: ـ تعرف الحروف بسر عة مناسبة. ـ التمييز بين الحروف المتشابهة صوتاً. ـ التمبيز بين الحروف المتتـابهة شكلاً. ـ التمييز بين الكلمات المتشابهة شكلاً. ـ التمييز بين حركات التتوين (تتوين القتح- تتوين الضم- تتوين الكسر). ـ التمييز بين حروف المد قراءة.

- مهارة النطق الصحيح: ويُقصد بها نطق الأصوات نطقاً صحيحاً من حيث المخرجالتمييز بالنطق بين الأصوات المتشابهة ـ نطق الحركات نطقاً دقيقاً. وتتضمن مهارة النطق الصحيح المهار ات التالية: - ينطق أصو ات الحروف نطقًا صحيحًا. - ينطق أصوات الحروف المنتابهة في المخرج نطقًا صحيحًا. - ينطق أصوات الحروف بحركاتها الثناث. - ينطق أصوت حروف المد نطقًا صحيحًا. ـ ينطق اللام القمرية و الثمسية نطقًا صحيحًا. - ينطق كلمات مكونة من حرفين فأكثر. - مهارة الفهم: ويُقصد بها القدرة على تحليل الكلمات والجمل، ونوليد عدد كبير من البدائل أو المرادفات أو الأفكار، واستنتاج المعنى من السياق. وتتضمن مهارة الفهم المهار ات التالية: - الية - فهم الجمل البسيطة. - فهم معاني الكلمات.

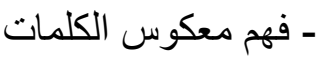


أثر برنامج قائم على الوعي الصوتي في تنمية مهارات القراعة الجهرية لاى التلاميذ ضعاف السمع بالمرحلة الإبتدائية

$$
\text { ـ ـ ـ ـ ـ الإجابة المناسبة عنى الكلمة من خلال السياق. }
$$

ولتنمية هذه المهارات قامت الباحثة ببناء برنامج قائم على مدخل الوعي

الصوتي، ذلك المدخل الذى سيتم سيتم تتاوله فيما يلي.

$$
\text { المحور الثالث: مدخل الوعي الصوتى: }
$$

يهدف هذا المحور إلى تحديد مهار ات الوعي الصوتي المناسبة للتلاميذ ضعاف

السمع بالمرحلة الابتدائية، وتحديد أسس مدخل الوعي الصوتي للاستناد إليها فى بناء برنامج تنمية مهارات القراءة الجهرية - بمختلف عناصرهـ للتلاميذ ضعاف السمع بالمرحلة الابتدائية، وكذلك تحديد خطوات و إجر اءات الاستراتيجية القائمة على مدخل الوعي الصوتي، و أدوار المعلم والمتعلم فيها، وتحقيقًا لهذه الأهداف يتم تناول الآتي:

$$
\text { - مفهوم مدخل الوعي الصوتي. }
$$$$
\text { ـ الدر اسات السابقة: }
$$

أـ التى تناولت الوعي الصوتي لدى التلاميذ ضعاف السمع.

ب- التى تنتاولت العلاقة بين الوعي الصوتي و القراءة الجهرية.

$$
\text { - مهار - مات الوعي الصوتي. }
$$

$$
\text { ـ ـ الوعي الصوتي و القراءة الجهرية. }
$$

- أسس مدخل الوعي الصوني لتنمية مهارات القراءة الجهرية للتناميذ ضعاف السمع بالمرحلة الابتدائية. 
د. حنان محمد فياض

- - خطو ات الاستراتيجية القائمة الوعي الصوتي، وأدوار المعلم و المتعلم فيها.

أولاً: مفهوم مدخل الوعي الصوتي:

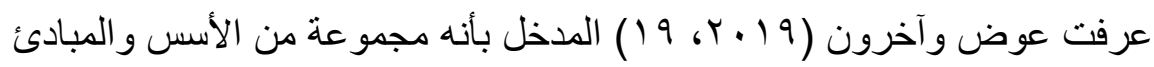

و الافتر اضات أو المسلمات التى تتعلق بطبيعة اللغة، وطبيعة تعليمها وتعلمها، وفى ضوء المدخل تتشكل أسس البرنامج اللغوي بمختلف عناصره: أهدافه، ومحتواه، وتتظيم محتو اه، و عمليات تتفيذه، و استر اتيجيات تدريسه، و أنشطته، ووسائله التعليمية، و أساليب تقويمه، مما يوفر المناخ والسياق الملائم لنجاح عملية تعليم اللغة، هو أساس يرتكز عليه تعلم اللغة وتعليمها. ذكرت Cynthia ) (2004, 6) أن الوعي الصوتي عبارة عن مجموعة من المهارات اللغوية التي تتضمن معالجة الوحدات الكلامية، مثل الكلمات، والمقاطع و الفونيمات.

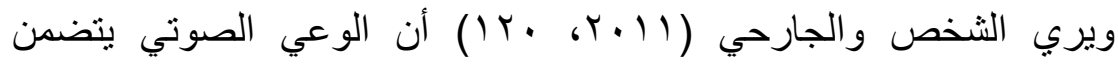

المهارات المتعلقة بالقدرة علي التعامل مع تركيب بنية الصوت في اللغة، وبتضدن الوعي الصوتي كل من الاستماع Phonemic والوعي الفونيمي، والو Awareness، والوعي بالمقاطع Syllabels Awareness، ووعي الكلمات

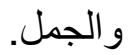

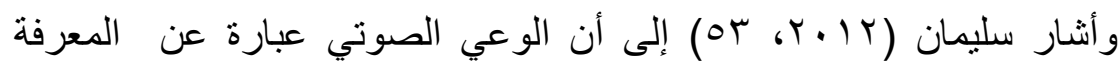
بالوحدات الصوتية كما هي ممثلة بالرسم الهجائي، وفهم العلاقات النظمية بين الحروف والفونيمات، وتجزئة الرموز التي تكون الكلمة، والقدرة على التعامل مع الرموزعلى مستوى الكلمة من خلال المزاوجة بين نطق الكلمة وتهجئتها، ويتحقق عن طريق التعلم للغة استماعًا و انتاجًا، وربطًا للقر اءة و الكتابة.

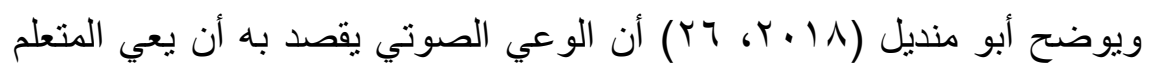
أن الكلام هو عبارة عن جمل، و الجمل عبارة عن كلمات، والكلمات عبارة عن مقاطع، 
أثر برنامج قائم على الوعي الصوتي في تنمية مهارات القراعة الجهرية لاى التلاميذ ضعاف السمع بالمرحلة الإبتدائية

والمقاطع عبارة عن أصوات منفردة ويكون لديه القدرة على ربط المكونات مع بعضها لإبكا البعض لتكوين لغة سليمة، و التلاعب بالأصو ات من خلال الحذف و الإضافة و التبديل و السجع.

وبناء على ما سبق يمكن تعريف الوعي الصوتي في البحث الحالي بأنه وعي التلاميذ ضعاف السمع بأن القراءة الجهرية تتضمن ربط الرموز المطبوعة بالأصوات التي تقابلها، و إدرالك التشابه والاختلاف بينها، وتقسيم الكلمة إلى أصوات ومقاطع، وقر اءة الكلمات الناتجة عن مزج الأصوات، والحكم على سجع وتقفية الكلمات، وتقسيم الجمل إلى كلمات.

ويمكن كذللك تعريف مدخل الوعي الصوتي فى البحث الحالي بأنه مدخل الوعي الصوتي في البحث الحالي بأنه مجموعة الأسس والمبادئ و الافتر اضات و المسلمات ذات العلاقة بطبيعة الوعي الصوتى، ومهار اته، وطبيعة تعليمه وتعلمه، و التىى تتشكل في ضوئها

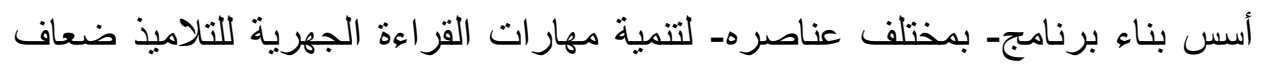
السمع بالمرحلة الابتدائية. ثانيًا: الاراسات السابقة فى هذا المحور، وتم تناولها من خلال ما يلي: أ- دراسات سابقة تناولت الوعى الصوتى لاىى التلاميذ ذوى الإعاقة السمعية:

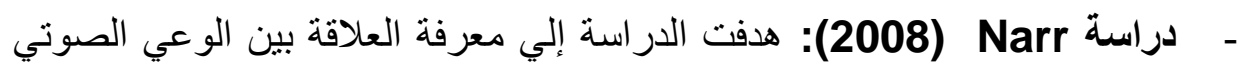

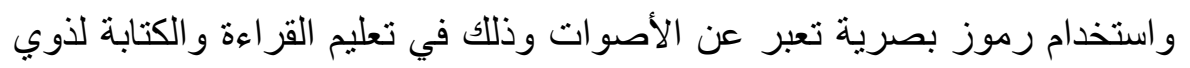
الإعاقة السمعية. وقد تكونت عينة الدراسة من (^) أطفال ذوي إعاقة سمعية من المستوى المتوسط للحاد، وطفل واحد ذي إعاقة سمعية من زارعي القوقعة، و هؤلاء الاطفال في الصفوف الدراسية من الأول حتى الثالث، وتتراوح أعمار هم بين 0- 1 أعوام، وجميعهم تم التدريس لهم بلغة الإشارة الأمريكية، واللغة الإنجليزية المدعومة بالإشارات وذللك بشكل يومي. واستخدت الدراسة كتب 
د. دنان محمد فياض

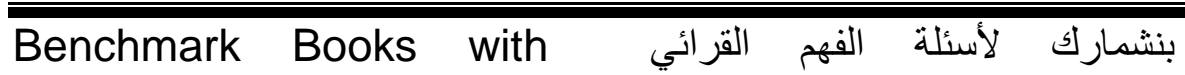
Comprehension Questions للقراءة، والتقييم القرائي داخل الفصل (Silavaroli, 1996 ). وقد أثنارت النتائج إلي أن تعليم القراعة للطلاب ذوي الإعاقة السمعية باستخدام رموز بصرية

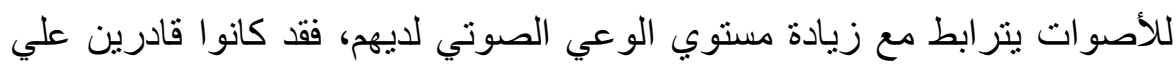
إتمام مهام الوعي الصوتي بشكل أفضل من المتوقع.

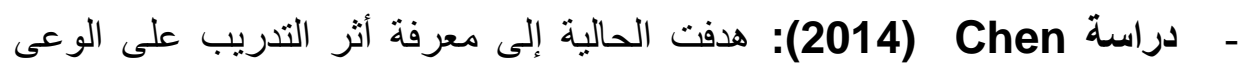

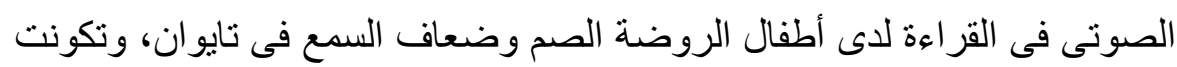
عينة الدراسة من (9 (1) طفلا موزعين على مجموعتين الأولى تجريبية وعددها

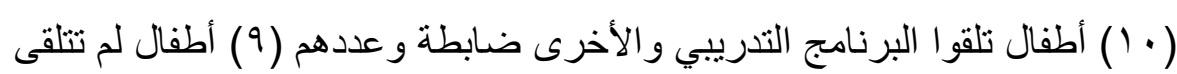
التدريب على الوعى الصوتى. واستخدم الباحث الأدوات التالية: مقياس الوعى ولى

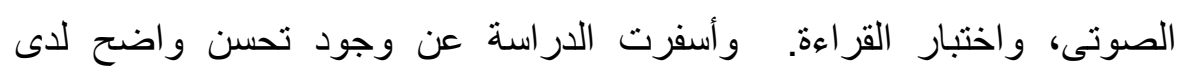

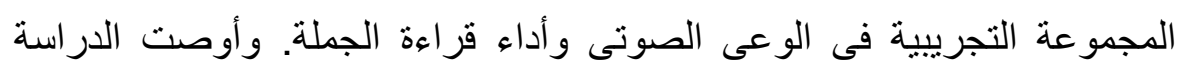

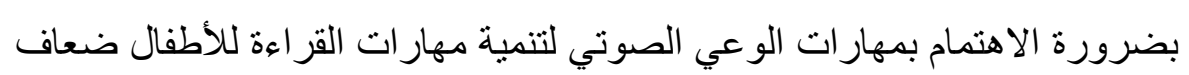
السمع فى مرحلة مبكرة. - دراسة Cupples, et al., علاقة بين الوعي الصوتي ومهارات القراءة للأطفال ذوي الإعاقة السمعية، في

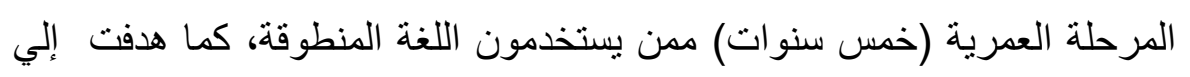

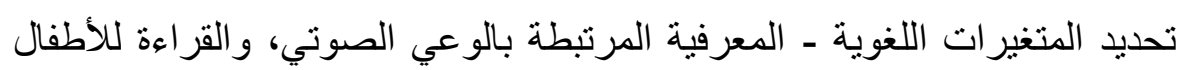
ذوي الإعاقة السمعية. وتكونت العينة من ( ( ـ 1) طفل من ذوي الإعاقة السمعية. واستخدمت الدراسة: اختبار اللغة التعبيرية The PPVT-4 ( Dunn \& Dunn, 2007) 
أثر برنامج قائم على الوعي الصوتي في تنمية مهارات القراعة الجهرية لاى التلاميذ ضعاف السمع بالمرحلة الإبتدائية

واختبار الوعي الصوتي (Wanger et al., 1999) CCTOPP. وبطارية

Woodcock Johnson III Diagnostic Reading تنخيص القراءة

Battery ( WJ III DRB) (Woodcock, Marther, \& Schrank, The Wechsler Individual 2004). Achievement Test- Second Edition, Australian Standerised (Wechsler, 2007). Edition (WIAT- II Australian) the Wechsler nonverbal Scale of the المعرفية غير اللفظية لويتنسلر ability (WNV) (Wechsler \& Naglieri, 2006). وأثنارت نتائج الدراسة إلي أن مهارات الوعي الصوتي تلعب الدور الأكثر أهمية في (WV

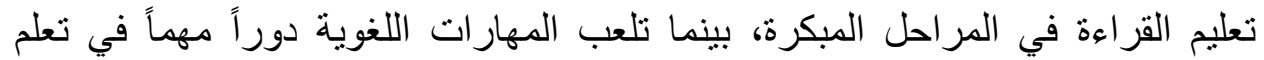
القر اءة في مر احل لاحقة. - دراسة Holmer et al.

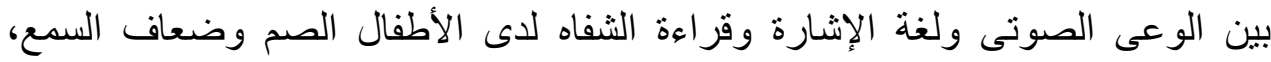
و التعرف على الفروق بين الصم وضعاف السمع فى الوعى الصوتى ولغة الإثارة وقراءة الثنفاه، وتكونت عينة الدراسة من مجموعة من الأطفال الصم وضعاف السمع، وقد الصداف استخدت مقاييس في الوعى الصوتى ولغة الاشتارة وقراءة الثفاه. وأسفرت نتائج الدراسة عن وجود علاقة دالة احصائيًا بين الوعى الصوتى ولغة الإثارة وقراءة الثنفاه

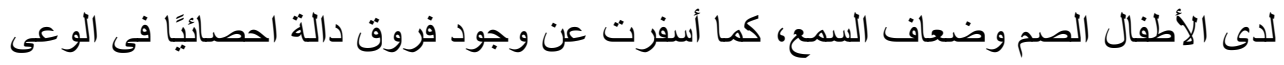
الصوتى ولغة الإشارة وقراءة الثفاه لاى الأطفال الصم وضعاف السمع، لصالح الأطفال

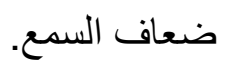
- دراسة حسن (17 + (Y) هدفت الدراسة إلى التعرف على مدي فعالية برنامج للتنخل

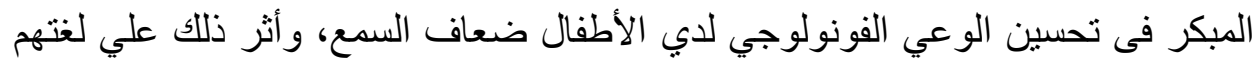


د. حنان محمد فياض

التعبيرية. وتكونت عينة الدر اسة من مجمو عتين (تجريبية وضابطة) نكونت كل مجمو عة من (7) أطفال ضعاف السمع تتراوح أعمار هم بين (ع- 7) سنوات، وتتراوح درجة

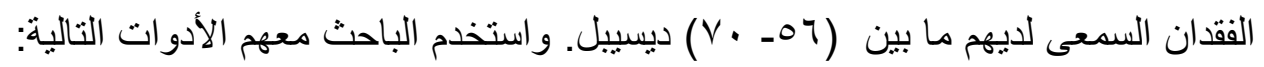
مقياس بينية للذكاء الصورة الخامسة، ومقياس اللغة التعبيرية للأطفال ضعاف السمع، ومقياس الوعي الفونولوجي للأطفال ضعاف السمع، وبرنامج التدخل المبكر لتنمية الوعي الفونولوجي لدي الأطفال ضعاف السمع. وأشارت النتائج إلي فاعلية برنامج التنخل المبكر فى تحسين مستوي الوعي الفونولوجي واللغة التعبيرية لاى الأطفال ضعاف السمع. - دراسة , Camarata, et al.,

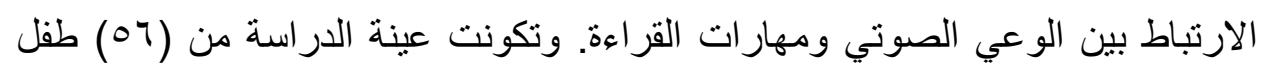

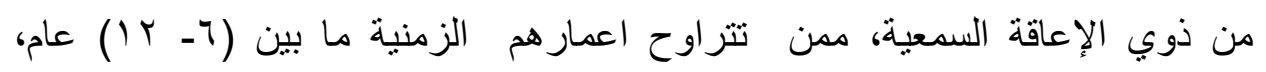

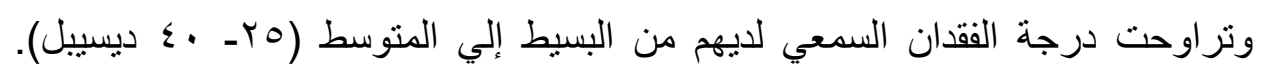
واشتملت أدوات الدر اسة علي:

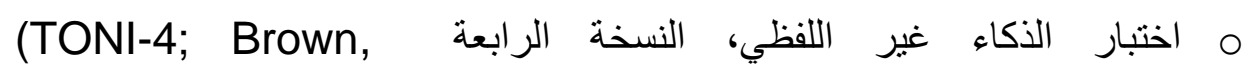
Sherbenou,\& Johnson, 2010)

م اختبار التفكير المعرفي (CELF-4; Semel, Wiig, \& Secord, 2003) م اختبار اللغة الاستقبالية والتعبيرية؛ الاختبار الثامل للمعالجة الصوتية (CTOPP; Wanger, Torgeson, \& Rashotte, 1999) م اختبار الوعي الصوتي، الذاكرة؛ اختبار وودكوك للقراءة، النسخة الثالثة (WRMT- III; WoodCook, 2011) وأثارت النتائج إلي وجود ارتباط إيجابي بين الوعي الصوتي ومهارات القر اءة، و أثر هذا الإرتباط علي تحقيق إنجاز اكبر في القراءة لدي الأطفال ذوي الإعاقة السمعية. 
أثر برنامج قائم على الوعي الصوتي في تنمية مهارات القراعة الجهرية لاى التلاميذ ضعاف السمع بالمرحلة الإبتدائية

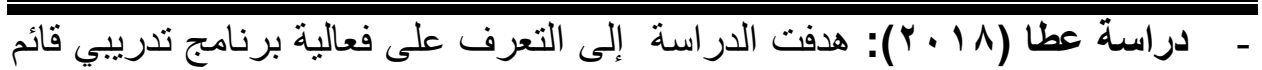
على الوعي الفولونوجي في تتمية المهارات السمعية لدى التلاميذ ضعاف السمع بالمرحلة الابتدائية، وتكونت عينة البحث من (^) تلاميذ بالصف الأول الابتدائي

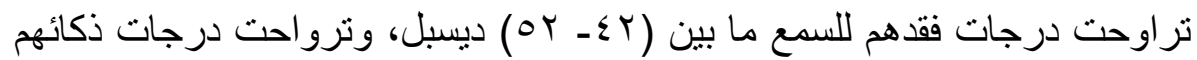

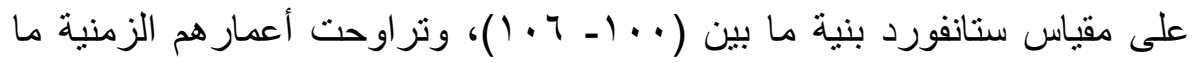
بين (7,0 - Y)، وتم تقسيمه بالتساوي إلى مجموعتين متكافئتين. وطبق الباحث البرنامج التدريبي وبطارية المهار ات السمعية (إعداد الباحث). وتوصلت النتائج إلى إنى فعالية البرنامج التدريبي القائم على الوعي الفونولوجي في تتمية المهارات السمعية لاى التلاميذ ضعاف السمع. - دراسة محمد (9 ( ـ ؟): هدفت الدراسة الحالية إلى تحسين مهار ات القراءة في اللغة الإنجليزية لاى الأطفال ذوي الإعاقة السمعية من خلال برنامج لتنمية مهارات الوعي الصوتي، والإدراك البصري والحصيلة اللغوية، والفهم القرائي باستخدام مجموعة متتوعة من الأنشطة والإستراتيجيات و الفنيات والأساليب المختلفة. وتكونت عينة الدر اسة من مجموعة تجرييبة واحدة تكونت من ( • () أطفال من ذوي الإعاقة السمعية، وتراوحت أعمار هم الزمنية ما بين (rا ـ 010) عام في الصف الأول الإعدادي من التعليم الأساسي. واستخدمت الباحثة الأدوات التالية: مقياس

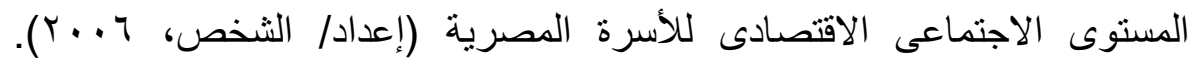

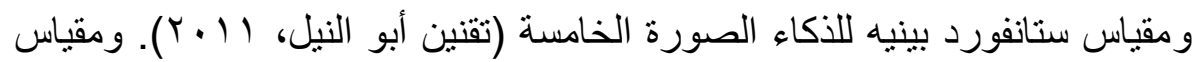
مهار ات القر اءة في اللغة الإنجليزية للأطفال ذوي الإعاقة السمعية. (إعداد/ الباحثة)

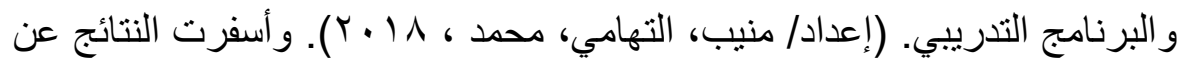
فعالية البرنامج التدريبي المستخدم فى تنمية مهارات القراءة في اللغة الانجليزية 
د. حنان محمد فياض

(مهارات الوعي الصوتي، مهارات الإدراك البصري، الحصيلة اللغوية، والفهم القرائي) لدي الأطفال ذوي الإعاقة السمعية. ب- الاراسات السابقة التىى تناولت الوعى الصوتى ومهارات القراعة الجهرية: ـ دراسة بابلي (9 ، . Y): هدفت الدراسة إلى استقصاء أثر برنامج تدريبي معرفي في تنمية مهار ات الوعي الصوتي على سرعة القراءة والاستيعاب القرائي للى طلبة صعوبات

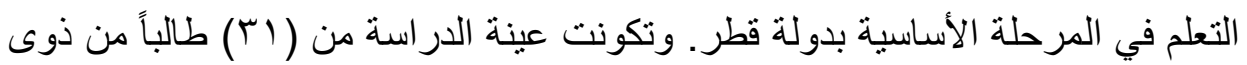
صعوبات التعلم والملتحقين بغرفة المصادر في الصف الرابع الأساسي للبنين، وتم تقسيمهم إلى مجموعتين الأولى تجرييية (10 طالبًا)، والأخرى ضابطة (7 1 طالبًا). وقام الباحث بتطبيق اختبار سرعة القراءة الجهرية (إعداد / الباحث)، واختبار الاستيعاب القرائي (إعداد/ الباحث)، واختبار المعالجة الصوتية المقنن للأطفال (إعداد/ البحيري و آخرون، ( • ب) و المقنن على البيئة الخليجية. و أظهرت نتائج الدراسة فعالية البرنامج التدريبي المعرفى فى تتمية مهارات الوعي الصوتي، و أثر ذلك الإيجابي على سرعة القر اءة و الاستيعاب القر ائي لدى التلاميذ ذوى صعوبات التعلم.

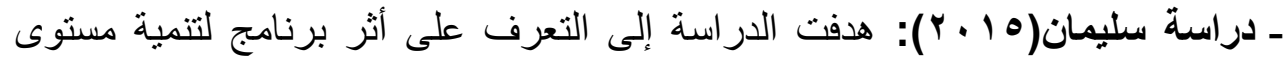
الوعي الصوتي في تحسين مهارات القراءة لدى عينة من الأطفال ذوي متلازمة داون، وكذلك معرفة مدى استمرارية فعالية البرنامج خلال فترة المتابعة. وتكونت عينة الدراسة من (·r) طفلاً من ذوي متلازمة داون بجدة. وتم تقسيمهم إلى مجمو عتين متجانستين تجريبية (أطفال • (1)، وضابطة (أطفال · ())، وعمر هم الزمني يتراوح من (^- r Y ) عام. واستخدم الباحث الأدوات الآتية: مقياس الوعي الصوتي لدى الأطفال ذوي متلازمة داون (إعداد/ الباحث). ومقياس مهارات القراءة لدى

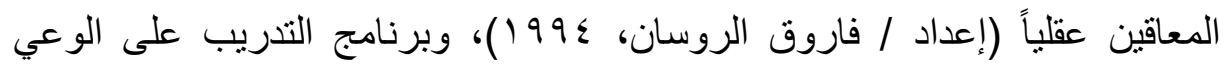
الصوتي في تنمية مهار ات القراءة لدى الأطفال ذوي متلازمة داون (إعداد/ الباحث). 
أثر برنامج قائم على الوعي الصوتي في تنمية مهارات القراعة الجهرية لاى التلاميذ ضعاف السمع بالمرحلة الإبتدائية

وأثنارت نتائج الدراسة إلى فعالية فعالية البرنامج المقترح فى تتمية مستوى الوعي الإبله الصوتي، وتحسين مهارات القراءة لاى الأطفال ذوى متلازمة داون. ـ دراسة Loudemil (2015 ) هدفت الدراسة إلى التعرف على العلاقة بين القراءة و الفهم القرائى ومهارات الوعي الصوتي. وتكونت عينة الدراسة من ( • ج) طالبة من طالبات الصف الرابع في و لاية أركنساس، وقد تم تقسيمهم إلى مجموعتين إحداهما تجريبية والأخرى ضابطة. ونوصلت نتائج الدراسة إلى وجود فروق ذات دلالة إحصائية بين المجموعتين لصالح المجموعة التجريبية، ووجود علاقة إرتباطية موجبة بين فهم القر اعة و الوعي الصوتي. ـ دراسة شتا (Y (1 (Y): هدفت الدراسة إلى تحديد أثر برنامج مقترح لتنمية الوعي الفونولوجي وأثره في تخفيف حدة العسر القرائي لدى تلاميذ الصف الأول الابتدائي ذوى صعوبات التعلم بمحافظة رفحاء بالمملكة العربية السعودية. وتكونت عينة الدراسة من (ع) تلميذاً من تلاميذ الصف الأول الابتدائي ذوي صعوبات التعلم تراوحت أعمار هم بين (ך - 7,0)، وتم تقسيمهم إلى مجمو عتين متساوينين في العدد: تجريبية وضابطة ( V Vلميذًا فى كل منهما). و اشتملت أدوات الدراسة على: مقياس الوعي الفونولوجي، واختبار تشخيص العسر القرائي، والبرنامج المقترح لتنمية الوعي الفونولوجي (إعداد الباحث). و أثنارت نتائج الدراسة إلى فعالية البرنامج المقترح فى تنمية الوعي الفونولوجي وتخفيف حدة العسر القرائى لذى التلاميذ ذوى صعوبات

$$
\text { التعلم بالصف الأول الابتدائي. }
$$

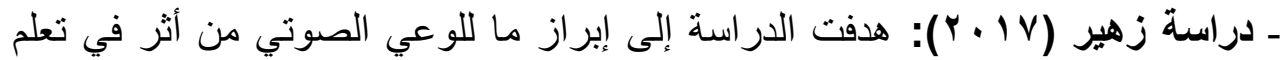
و استيعاب مهارة القراءة باعتبار ها وظيفة معرفية. وتكونت عينة الدراسة من ( . ( ) طفل متمدرسًا بالطور الابتدائي بالجزائر و الذين تتراوح أعمار هم ما بين (9- (1) (1)، وتم اختيار العينة بطريقة عشوائية من إناث وذكور لا يعانون من أي اضطرابات 
د. حنان محمد فياض

بصرية وسمعية. ولتحقيق الدراسة تم اتباع المنهج الوصفي لإثبات أو نفي العلاقة الحاصلة بين هذين المتغيرين. وتم تطبيق اختبار الوعي الفونولوجي الفرنسي مأخوذ من كتاب الباحث (Delpech). حيث تكاد تجمع الدراسات التي أجريت على مدى السنوات المنقضية على الارتباط و أهمية الوعي الصوتي في عملية الاستيعاب القرائي وتعلم القراعة بشكل عام. وأسفرت نتائج الدراسة عن وجود علاقة ارتباطية قوية بين الوعي الصوتي و الاستيعاب لاى مجموعة البحث.

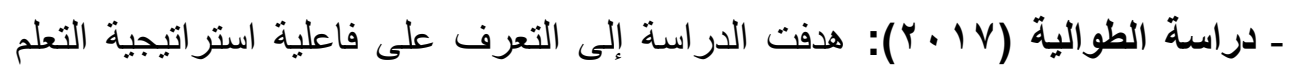
النشط في تحسين مهار ات الوعي الصوتي وفهم المسموع لدى طلبة الصف الخامس من محافظة مادبا. وتكونت عينة الدراسة من ( • (7) طالبة بالصف الخامس الأساسي، وتم تقسيمهم عشوائيًا لمجموعتين متساويتين إحدهما تجريبية، والأخرى ضابطة.

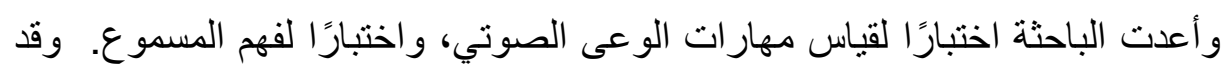

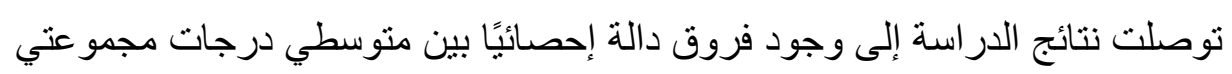

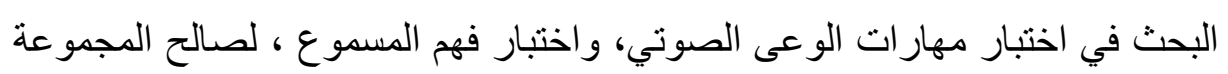
التجريبية، و تعزي إلى نوع استر اتيجية التدريس (التعلم النشط/ الاعتيادية). كما توجد ولدئ فروق دالة دالة إحصائياً بين متوسطي إفراد عينة البحث في اختبار فهم المسموع إنئه تعزي إلى استر اتيجية التنريس (التعلم النشط/ الاعتيادية).

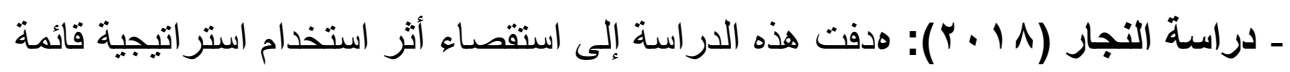
على مدخل الوعي الصوتي في تنمية مهارة القراءة الجهرية والاستيعاب القرائي لدى طلبة الصف الثالث الأساسي في مادة اللغة العربية، وبيان إذا كان هذا الأثر يختلف باختلاف طريقة التدريس والجنس و التفاعل بينهما. وتكونت عينة الدر اسة من (rع ( ) طالباً وطالبة، موزعين على أربع شعب دراسية، شعبتان تمثلان المجموعة التجريبية

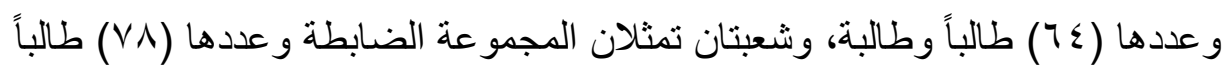

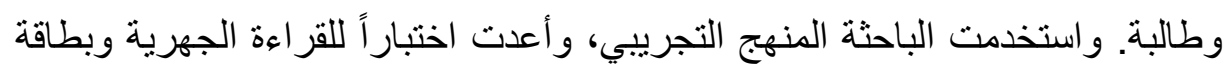

$$
\begin{aligned}
& \text { العدد الخامس والاربعون (الجزء الاول) I. r. } \\
& \text { مجلة كلية التربية- جامعة عين شمس (423) }
\end{aligned}
$$


أثر برنامج قائم على الوعي الصوتي في تنمية مهارات القراعة الجهرية لاى التلاميذ ضعاف السمع بالمرحلة الإبتدائية

ملاحظة، واختبار أ للاستيعاب القر ائي، ودليل للمعلم. وقد أظهرت نتائج الدراسة فعالية استراتيجية الوعي الصوتي فى تتمية مهار ات القراءة الجهرية والاستيعاب القرائي

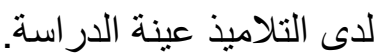

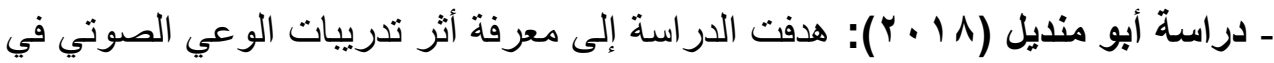
تنمية مهارات القر اء الجهرية لدى تلاميذ الصف الرابع من ذوب صعوبات التعلم داخل

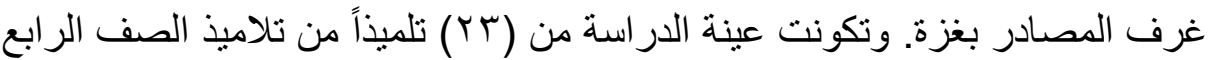
الأساسي، وتم تقسيمهم إلى مجموعتين، الرابع وعددهم (Y (Y)، والرابع وعددهم (1')، وقام الباحث بتحديد مهارات القراءة الجهرية المناسبة، وإعداد التدريبات القائمة على الوعي الصوتي بما يتناسب مع تلاميذ الصف الرابع من ذوي صعوبات التعلم، وإعداد بطاقة ملاحظة لقياس مهار ات القر اعة الجهرية. و أظهرت النتائج وجود فروق ذات دلالة إحصائية بين متوسطي درجات المجموعة التجريبية في التطبيقين القبلي والبعدي لبطاقة ملاحظة مهارات القراءة الجهرية لصالح التطبيق البعدي، كما أظهرت النتائج أن تدريبات الوعي الصوتي كان لها أثر كبير في تنمية مهارات

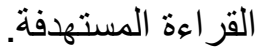

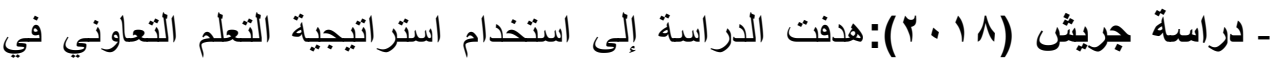
تحسين الوعي الفونولوجي والقراءة الجهرية لدى التلاميذ ذوي صعوبات تعلم القراءة (الديسليكيا)، وتكونت عينة الدراسة من (r ( ) طفلاً ترواحت أعمار هم ما بين (1-. ( ) سنوات، وتم تقسيمهم لمجموعتين متساويتين إحداهما تجريبية و الأخرى ضابطة. و اشتملت أدوات الدراسة على: اختبار ستانفورد - بينية لقياس الذكاء الصورة الرابعة (تعريب مليكه، 991 ())، واستمارة دراسة الحالة اضطر ابات اللغة والكلام (إعداد/ الثخص، 997 ( ))، ومقياس اضطرابات اللغة والكلام (إعداد/ الثخص، 999 ())، ومقياس تقييم النطق (إعداد/ الثخص، و997) )، ومقياس تشخيص صعوبات القراءة 
د. حنان محمد فياض

(إعداد/ الزيات)، وبرنامج تلدريبي باستخدام التعلم التعاوني لتحسين الوعي الفونولوجي والقراءة الجهرية لدى الأطفال ذوي صعوبات علم القراءة (الديسليكيا) (إعداد/ الباحثة). وتوصلت نتائج الدراسة إلى فعالية التعلم التعاوني في تحسين الوعي الفونولوجي و القر اعة الجهرية لدى تلاميذ المجمو عة التجريبية. ـ دراسة لعريبي (1 ا • Y): تهدف هذه الدراسة إلى تحديد دور الوعي الصوتي للطفل الأصم في تعلم القراعة، وتكونت عينة الدراسة من (Tr) طفلاً موزعين على مجموعتين، المجموعة الأولى (اب) من الأطفال الصم الحاملين للزرع القوقعي، و المجموعة الثانية (1) طفلا وطفلة من الأطفال الصم المجهزين كلاسيكيًا. وترواحت أعمار هم الزمنية ما بين (9- (1) سنة من تلاميذ الصف الرابع والخامس الابتدائي. وقامت الباحثة بتطبيق إختبار الذكاء المصور لأحمد زكي، واختبار كولومبيا Colombia، و اختبار الوعي الفونولوجي. وتوصلت نتائج الدراسة إلى وجود فروق في الوعي الفونولوجي عند المجموعات الثلاثة (الأطفال الصم الحاملين للزرع القوقعي، الأطفال الصم المجزين كلاسيكيا، والأطفال السامعين). وأن هذه الفروق راجعة إلى أن الأطفال الذين استفادوا من الزرع القوقعي وكان التجهيز مبكراً لديهم نتائج حسنة وجيدة، مقارنة بالأطفال الصم المجزين كلاسيكيًا. ـ دراسة.2018) Mohammed, et al) : هدفت الدراسة إلى المقارنة بين ذوي الزرع القوقعي وضعاف السمع للكثف عن مستوى الوعي الفونولوجي عند التلاميذ الصم المدمجين بالمدرسة العادية بعد التجهيز سواء كان بالزرع القوقعي أو بالمعين السمعي. وتكونت عينة الدراسة من ( •0) طفلًا متوزعين على عدة مدارس، تثراوح أعمار هم بين (9- 11) سنة. ولجمع البيانات تم الاعتماد على اختبار الذكاء غير اللفظي للصم إعداد (مكرومي)، واختبار الوعي الفونولوجي المعد من الباحثة (أزداو شفيقة، r ا • Y). وللتعرف على الكلمة المكتوبة تم تطبيق الاختبار الفرعي (التعرف على الكلمات) لبطارية تقييم القدرات الإداركية والسمعية والإنتاج الكلامي إعداد 
أثر برنامج قائم على الوعي الصوتي في تنمية مهارات القراعة الجهرية لاى التلاميذ ضعاف السمع بالمرحلة الإبتدائية

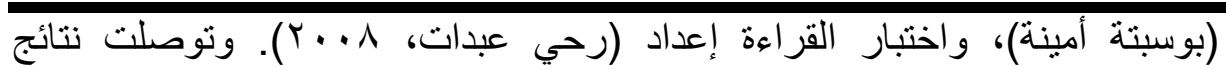
الدراسة إلى عدم وجود فروق في الوعي الفونولوجي بين الأطفال ذوي الزرع القوقعي وضعاف السمع بالر غم من اختلاف المجموعتين في شدة الإعاقة السمعية إلا أن كلاهما لديه ضعف في القدارت الميتالغوية (الوعي الفونولوجي)، وهذا ما يؤثر على الاكتسابات اللغوية كالقراءة والتعرف على الكلمات المكتوبة. كما وجدت علاقة ارتباطية موجبة بين الوعي الفونولوجي والتعرف على الكلمة المكتوبة لدى كل من الأطفال ضعاف السمع، وذوي الزرع القوقعي، وهو ما يفسر دور الوعي الفونولوجي في مستوى التحكم في القراءة.

ـ دراسة حمدان، والبلوي (9 (19): هدفت الدراسة إلى تطوير برنامج محوسب وقياس أثره في تحسين مهارات الوعي الصوتي لاى الأطفال ذوي صعوبات القراءة، وتكونت عينة البحث من (T؟Y) طالبًا من الطلبة ذوي صعوبات القراءة الملتحقين بغرف المصادر، ممن تتراوح أعمار هم من (Y-9 ( ) سنة، وتم اختيار هم بطريقة قصدية بناء على ترشيح من مدر اء المدارس، وبناء على تقارير تشخيصهم بأن لديهم صعوبات تعلم وتحديدًا صعوبات قر اعة، وتم تقسيمهم بطريقة متكافئة إلى مجمو عتين: مجمو عة تجريبية، ومجموعة ضابطة، تكونت كل مجموعة من (r ا ( طالبًا، واشتمل البحث على اختبار الوعي الصوتي، و البرنامج التدريبي المحوسب، وهما من إعداد الباحثني. وقد توصلت نتائج البحث إلى وجود أثز للبرنامج التدريبي في تحسين مهار ات الوعي الصوتي لاى الطلبة ذوي صعوبات القر اءة. وقد أفادت الدراسة الحالية من الدراسات السابقة فى هذا المحور فيما يلي: ـ تحديد بعض العوامل التى تزيد من الوعي الصوتي لدى التلاميذ ضعاف السمع، مثل

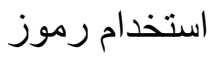




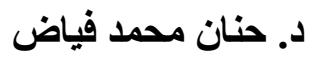

بصرية للأصوات (Narr, 2008)، وهو ما سينعكس إيجابيًا على مستوى القراءة لاى التلاميذ ضعاف السمع وخاصة فى ضوء ما أثبتته الدراسات السابقة من وجود علاقة ارتباطية إيجابية بين القراءة والوعى الصوتي وكذللك توجد علاقة إيجابية بين (Chen, 2014; Cupples, et الوعي الصوتي ولغة الإشارة وقراءة الثشفاة al., 2014; Holmer et al., 2016) ـ تحديد بعض العوامل التى تساعد فى تتمية مهارات القراءة لدى التلاميذ ضعاف السمع، مثل: تنمية مهارات الإدر اك البصري، و القدرة على الفهم و زيادة الحصيلة اللغوية

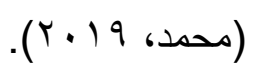

ـ التأكيد على العلاقة الإيجابية بين الوعي الصوتي ومهارات القراعة الجهرية لاى عديد Loudemil, et al., من فئات التلاميذ، سواء من العاديين، كما فى دراسة

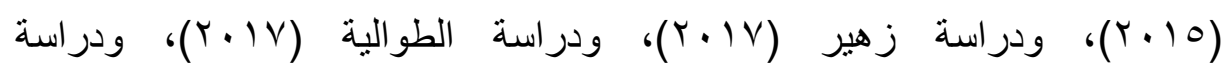

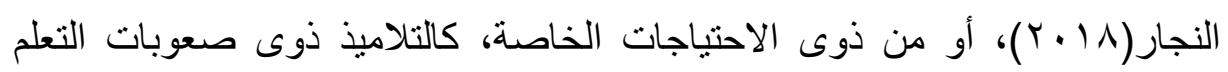

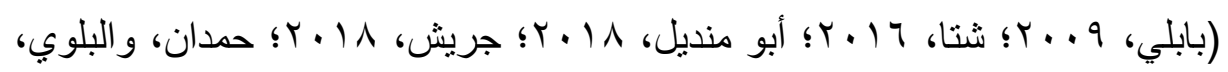

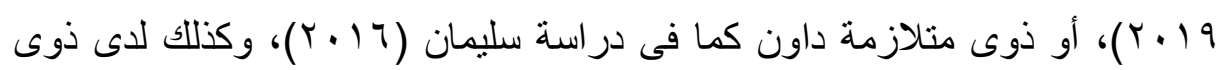
الإعاقة السمعية كما فى دراسة بل Camarata, et al.,2018، ودراسة العريبي $(Y \cdot 1 \Lambda)$

ـ الاستفادة مما تضمنته الدراسات السابقة من استراتيجيات ثبتت فعاليتها فى تتمية الوعي الصوتي ومهارات القراءة الجهرية لاى فئات أخرى من التلاميذ، مثل استراتيجية

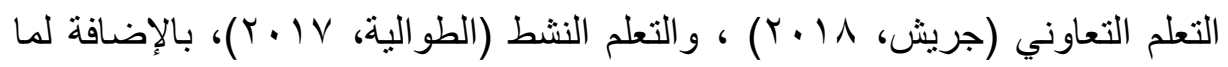
تتضمنته هذه الدر اسات من اختبار ات ومقاييس للقر اءة و الوعى الصوتي. ثنالثًا: مهارات الوعي الصوتي: هى مجموعة المهارات أو الأنشطة التي يمكن التدريب عليها لتنمية الوعي

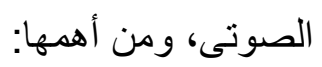


أثر برنامج قائم على الوعي الصوتي في تنمية مهارات القراعة الجهرية لاى التلاميذ ضعاف السمع بالمرحلة الإبتدائية

- عزل الفونيم Phoneme Isolation: ويعنى عزل الأصوت المفردة بالكلمة، و على التلميذ التعرف على الصوت الأول والأوسط والأخير في الكلمة ،مثال: ما

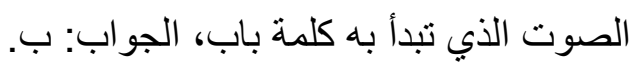
- مزج الأصوات Phoneme Blending: ويعنى ضم الأصو ات معًا لتكون كلمة، مثال: ما الكلمة التي تتكون من أصوات (م - و - ز)، الجواب: موز. ـ فصل الأصوات Phoneme Segmentation: أي تجزئة الكلمة إلى أصوات منفصلة عن بعضها مثال: ما الأصوات التي تتكون منها كلمة قلم، الجواب: ق ل- م. - حذف الأصوات Phoneme Deletion: ويعنى نطق الكلمة بعد حذف صوت منها، مثال: كلمة فأر، انطقها بدون صوت (ف)، الجواب : أر. - إبدال الأصوات Phoneme Substitution: ويعنى استبدال صوت واحد في الكلمة بصوت آخر، مثال: كلمة قط إذا تغير(ق) إلى (ب) ماذا تكون الكلمة، الجواب: بط (Torgeson, 2001,187). ومن تصنيفات مهار ات الوعي الصوتي التي يمكن أن يستضاء بها في التخطيط للأنشطة التصنيف التالي: يبدأ بالمستوى البسيط ويتضمن الوعي بأن الجملة والعبارة يمكن أن تقسم إلى كلمات مفردة، والوعي بأن الكلمات نشترك في بعض أصواتها، أو في السلاسل الصوتية المكونة لها. - ويضم المستوى المتوسط مهارتي الوعي بأن الكلمات تتكون من مقاطع، و أن هذه المقاطع يختلف عددها باختلاف الكلمات. - أما المستوي العميق فيشمل على الوعي بأن تغير صوت في الكلمة ينتج عنه كلمة جديدة، و الوعي بأن الكلمة تتكون من فونيمات، وعدد الفونيمات التي تتكون منها

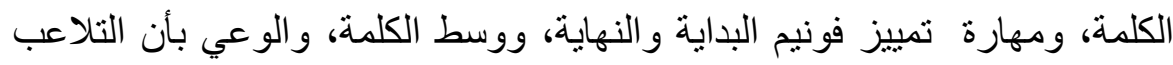




\section{د. حنان محمد فياض}

فونيمات الكلمة بتغيير مواضع الفونيمات فيها، وأخيرًا مهارة مزج الفونيمات لتكوين كلمات.

و هذا التصنيف لمهارات الوعي الصوتي تصنيف هرمي يبدأ بالوحدات الأكبر

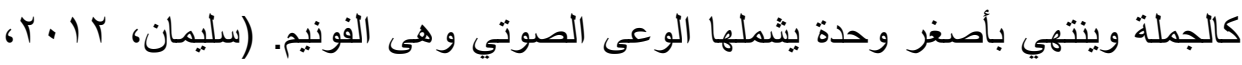
$(\wedge \vee-\wedge T$

وقد ذكر عبد السلام (10 ب أن أن الوعي الصوتي يتضمن خمسة مستويات على المتعلمين القيام بهاعلى النحو الآتي: - - تقسيم الجمل إلى كلمات: فعلى التلاميذ معرفة أن الجمل مكونة من كلمات، وبهذا يعى التلميذ أن الكلمة مكونة من مجموعة من الأصوات، وأن لكل كلمة حدوداً سمعية صونية. - - تقسيم الكلمات إلى مقاطع: أن تقسم الكلمات إلى مقاطع أسهل من تقسيمها إلى أصوات، وإذا ما أتقن الطفل في رياض الأطفال تقسيم الكلمات إلى مقاطع فإنه يعد إنى إنى مؤشراً على الأداء القرائي للطفل في الصف الصأف الأول. - التنغيم: هو أحد مجالات اللعب باللغة، فهو مؤشرعلى قدرة الطفل على الإتيان بكمات لها نفس النغمة يعد مؤشر اً على النجاح في القر اعة مستيتقبلاً.

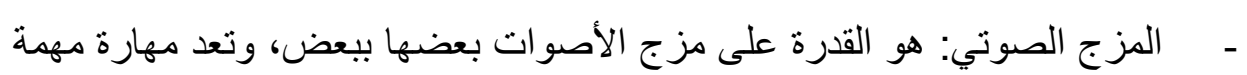
للقارئ المبتدئ. - تقسيم الكلمات إلى أصواتها: إن تقسيم الكلمات إلى أصواتها هو آخر مستويات

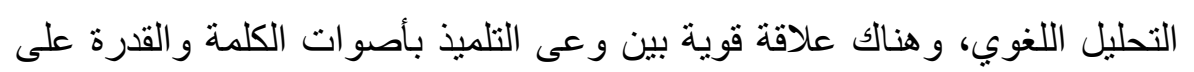
القر اءة.

ومن خلال الإطلاع على كتابات عديد من الباحثين بثأن مهارات الوعي

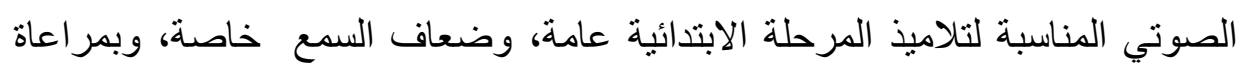

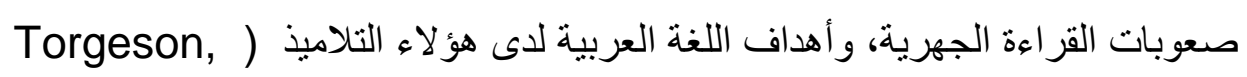


أثر برنامج قائم على الوعي الصوتي في تنمية مهارات القراعة الجهرية لاى التلاميذ ضعاف السمع بالمرحلة الإبتدائية

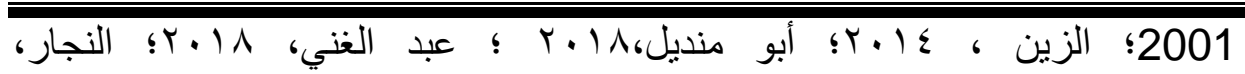

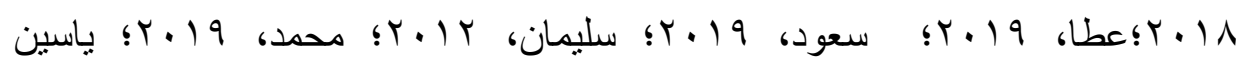
وآخرون، د- ت) أمكن تحديد عدد من مهارات الوعي الصوتي المناسبة للنلاميذ

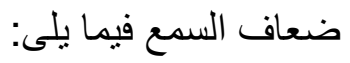
ـ تحليل أصوات الحروف: يعني قدرة التلميذ على التعرف على أصوات الحروف، و ادر الك التشابه و الاختلاف بينها وتحديد موقعها (بداية، وسط، نهاية) الكلمة المفردة،. ـ تقسيم الكلمات إلى أصوات: أن يحدد التلميذ الأصوات التي تتكون منها الكلمة مثل

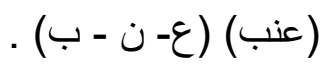
ـ تقسيم الكلمات إلى مقاطع: أن يحدد التلميذ عدد المقاطع الصوتية التي تتكون منها الكلمة مثل: تفاحة (تو - فا- حة) - مزج الأصو ات: أن يمزج التلميذ أصوات الحروف المنفردة مع بعضها لتكوين كلمات لها معني مثل (ع- ل- م)، (علم). - سجع وتقفية الكلمات: تعني قدرة التلميذ على تمييز الكلمات التي لها نفس السجع أو

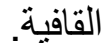
- الحكم على القو افي: يجب على التلميذ أن يقرر إذا كانت أزو اج الكلمات تقفي مثلا (يد-خد). - اختيار كلمة تقفي مع الكلمة المقصودة: يجب على التلميذ أن يختار من بين ثلاثة مقترحة الكلمة التي تقفي مع الكلمة المقصودة ـمثال: حوت / عنب، شبالك، توت. ـ تقسيم الجمل إلى كلمات: أن يقوم التلميذ بتحليل الجملة إلي عدد الكلمات التي تتكون

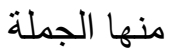
مثل: أحمد يحب الموز. (أحمد - يحب- موز). 


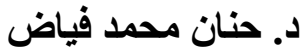

و هذا التصنيف لمهارات الوعي الصوتي تصنيف هرمي يبدأ بالوحدات الأصغر كالأصوات وينتهي بأكبر وحدة يشملها الوعى الصوتي وهى الجملة بما يتناسب مع بري خصائص واحتياجات التلاميذ ضعاف السمع. رابعًا: الوعي الصوتي والقراءة الجهرية:

ترجع أهمية الوعي الصوتي فى القراءة إلي أنه يعتبر ضروريًًا حتي يتمكن الطفل من معرفة الحروف الهجائية و إدراكها، فإذا ما أدرك الطفل أن بإمكاننا أن نقوم بتجزئة الكلمات إلي فونيمات مستقلة وأن نقوم بضم تللك الفونيمات معًا كي نتمكن من تكوين الكلمات المختلفة، فسيكون بمقدوره الربط بين الحرف والصوت الذي يدل عليه

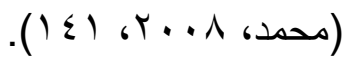

و العلاقة بين الوعي الصوتي و القراءة علاقة منبادلة ومتداخلة، فالوعي الصوتي من جهة هو أفضل منبئ بالاستعداد للقراءة خلال فترة ما قبل المدرسة. ومن جهة أخرى فلكي يتعلم الطفل القراءة يحتاج للوعى بالجوانب الصوتية للكلام، ويعني ذلك قدرة الطلل على التهجي والتعرف على الكلمات، وكي يصبح المتعلم قارئًا جيدًا يجب عليه تعلم التطابقات المتنوعة بين الحروف وصورها الصوتية، فالقراءة تتضمن الربط بين المنطوق والمكتوب، وعمليات تحليل وتركيب للوحدات الصوتية، ونطق لمقاطع تتشكل

$$
\text { من صوت أو أكثر }
$$

Chard\&Osborn,1999;

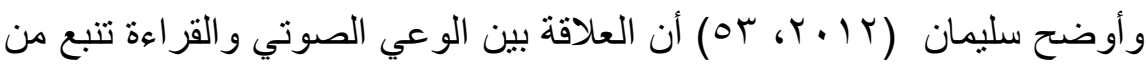
متطلبات نظام الكتابة الذي نريد أن يقرأ به الأطفال، ففي نظام اللغة العربية الهجائي تكون المهام الأساسية التي تواجه القارئ المبتدئ تكوين الرابطة بين الرموز المكتوبة وأصوات الكلام، ودمج الرموز الصوتية في مقاطع، ودمج المقاطع في كلمات، ونطق

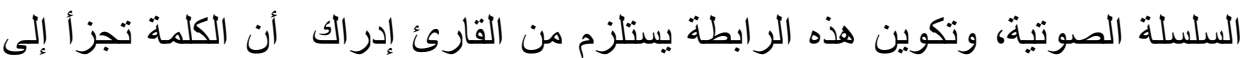
وحدات أصغر تمثل في حقبقتها صورة كتابة هجائية، ومن ناحية ثانية التلفظ بالكلمة 
أثر برنامج قائم على الوعي الصوتي في تنمية مهارات القراعة الجهرية لاى التلاميذ ضعاف السمع بالمرحلة الإبتدائية

ينضوى على تجميع معلومات صوتية حول كل وحدة صوتية، ويساعد إدراك أصوات الوحدات التي تتتكل منها الكلمة في سبب كتابتها بهذه الصورة.

ولكي يتم إعداد الأطفال للقراءة لابد من تنمية الوعي الصوتي لديهم في وقت

مبكر؛ وذللك عن طريق الأغاني واللعب بالأصوات، والحصول علي كلمات لها نفس القافية، وتمييز الاختلاف بين الصوت الأول والصوت الأخير للكلمات، والتدريب على مزج وتقسيم الأصوات داخل الكلمة، ودعم ذلك بتدريبهم علي الربط بين هذه الأصوات والحروف (Michel, 2007:381).

ويمكن إبراز أهمية الوعي الصوتي في تعليم القر اءة لتلاميذ المرحلة الابتدائية

في النقاط التالية:

- يساعد التلاميذ على تعلم القر اءة.

ـ يمثل تعليم الوعي الصوتي أكثر فائدة لتعليم القراءة للتلاميذ من التدريس الضمني. - بعمل على تتمية مهار ات التعرف وفلك الترميز لاى التلاميذ الضعاف في القراءة.

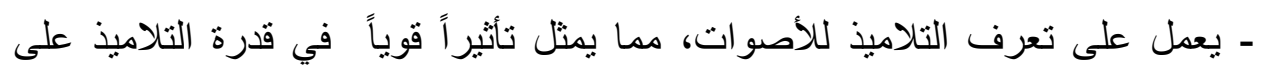
تعرف الكلمات.

- يعتمد القراء الذين يجيدون مهارات التعرف على إلماحات السياق بصورة أقل من

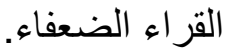
- يعمل على زيادة انتباه القارئ لكل حرف في الكلمة، مما يتفق مع طبيعة عملية القر اءة. ـ الوعي الفونيمي، وهو أحد مكونات الوعي الصوتي، يمثل ضرورة أساسية لزيادة

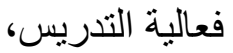
بمدخل الوعي الصوتي. - يحسن من القدرة الإملائية و الكتابية لدي التلاميذ. 
د. حنان محمد فياض

- يزيد من قدرة المعلم على التأثير في التلامبذ مما بعجل بتتمية مهار اتهم في القراءة؛ نتيجة معرفة

المعلم للأصوات، وفدرته على استخدام مدخل الوعي الصوتي في تدريس التلاميذ.

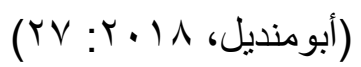

وقد أكدت نتائج عديد من الدراسات على أهمية تنمية الوعي الصوتي في تحسن مهار ات القر اءة لدى التلاميذ عامة، وضعاف السمع خاصة مثل در اسة (الشـاهين،

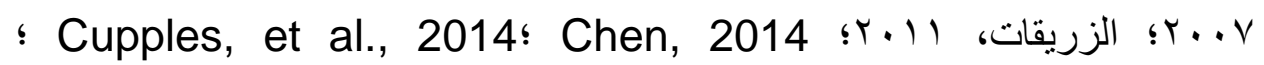

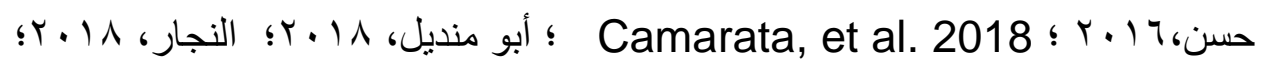
محمد، 19

\section{- خامسًا: الوعي الصوتي لاي ضعاف السمع:}

يعتبر الاضطر اب في الوعي الصوتي من الأسباب الرئيسة لمشكلات القراءة التي يعاني منها ذوو الإعاقة السمعية، وهذا الإضطراب في الوعي الصوتي يرجع لعدم قدرة الطفل ذى الإعاقة السمعية علي التحكم في تدفق النفس والصوت، وبالتالي عدم قرتهه علي تقليد الأصوات التي يسمعها من الآخرين. كما نجد أن الجهاز التنفسي للأصم وضعيف السمع أقل مرونة من الشخص السامع، فنلاحظ إما ارتفاع غير عادي للصوت،

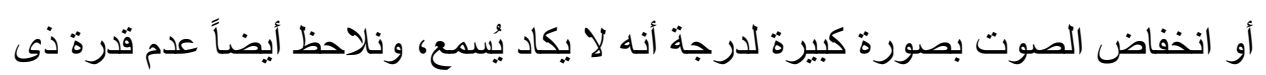
الإعاقة السمعية علي تنظيم كلامه، وضبط إيقاعه حيث يصدر أصواتًا علي وتيرة واحدة، ليس فيها ارتفاع أو انخفاض في درجة الصوت (سالي، 9 ( • ك، Vr).

وقد أكدت عديد من الدراسات على وجود علاقة إيجابية تبادلية بين الوعي الصوتي والمهارات السمعية حيث كثفت دراسة Narr (2008) عن فعالية برنامج تدريبي قائم على الوعي الفونولوجي (الصوني) المصحوب بالمثيرات البصرية في تحسين مستوى الانتباه والإدراك السمعي والقدرة على القراءة لدى الأطفال ضعاف السمع بالروضة. في حين خلصت دراسة (Miller,et.al; 2013) إلى الكثف عن 
أثر برنامج قائم على الوعي الصوتي في تنمية مهارات القراعة الجهرية لاى التلاميذ ضعاف السمع بالمرحلة الإبتدائية

العلاقة الموجبة بين تطور الوعي الفونولوجي (الصوتي) وتحسين مستوى الانتباه السمعي، وتطور اللغة لاى الأطفال ضعاف السمع.

و أثشارت عديد من الدراسات إلى أن التلاميذ ضعاف السمع يعانون من قصور

في مهار ات الوعي الصوتي، ومن ذلك دراسة (2009.Ambrose)، ودر اسة (2014 (Chen,

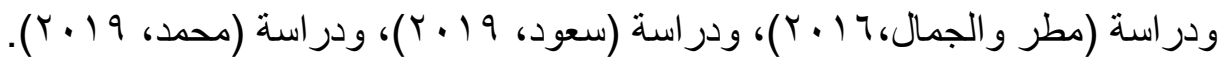
ـ سادسًا: أسس مدخل الوعي الصوتي لتنمية مهارات القراءة الجهرية للتلاميذ ضعاف السمع بالمرحلة الابتدائية:

يشكل هذا المدخل إطارًا عامًا لأى برنامج لتعليم القراءة الجهرية، ويبنى على الهى

مسلمات منها:

م أن المعاني فى الذهن، وأن الألفاظ هى أصوات ترمز إلى تللك المعاني، وأن الكتابة

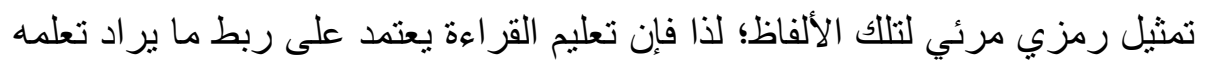
(الثكل الكتابي) باللفظ، ثم استحضار المعنى، وهكذا إلى أن يتمكن التلميذ من الربط المباثر بين الرموز والمعاني دون المرور بالألفاظ، ويقتصر استخدام الربط غير المباثر بين الرموز و المعنى باستخدام مهار ات التحليل الصوتي على الكلمات غير المألوفة أو الجديدة. م أنه توجد علاقة وثثقة بين مدخل الوعي الصوتي وتنمية المهار ات القرائية وخاصة فى الصفوف الأولى؛ لأن تتمية قدرة التلميذ على تجزئة الكلمات إلي فونيمات مستقلة، وضم هذه الفونيمات معًا تساعده على التمكن من تكوين كلمات مختلفة، ومن القدرة على الربط بين الحروف و المقاطع و الكلمات و الأصوات التى تدل عليها، وهو 


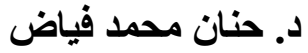

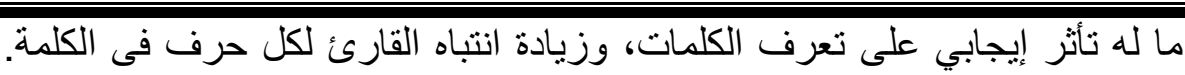

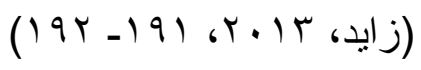

- سابعًا: خطوات استراتيجية قائمة على مدخل الوعي الصوتي، وأدوار المعلم

والمتعلم فيها:

يقصد بالاستر اتيجية سلسلة من الإجر اءات المحددة والمنظمة التى يضعها الفرد

لنفسه أو تفرض عليه لكى يحقق هدف ما. (Schmidt, et al. , 2002,130) وتعتبر الاستراتيجية القائمة على مدخل الوعي الصوني من الاستراتيجيات المهمة التي تتطلب من القارئ القرة على التحكم في تفكيره، ومراقبته قبل القراءة الجهرية، وفي أنثائها وبعدها.

ومن خلال الإطلاع على عديد من الكتب و الدراسات السابقة (الزيات، ؟ . . r؛؛

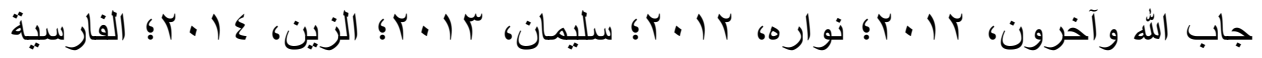

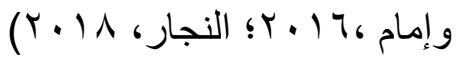
يمكن تحديد خطوات الاستر اتيجية القائمة على مدخل الوعي الصوتي وما تتطلبه من أدوار يقوم بها المعلم و المتعلم كما يلي:

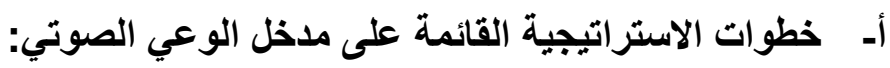
تعتمد الاستراتيجية القائمة على مدخل الوعي الصوتي على مجموعة من الخطوات، التى تتمثل في المعرفة بالوحدات الصوتية، وفهم العلاقات بين الحروف والأصوات، والقدرة على التعامل مع الرموز على مستوى الكلمة من خلال المزاوجة بين النطق والتهجئة، وتصنيف الأصوات حسب موضع الصوت بالكلمة في بدايتها ووسطها ونهايتها، و إدر الك التشابه والاختلاف بينها، وتقسيم الكلمة إلى أصو ات ومقاطع، وقر اءة الكلمات الناتجة عن مزج الأصوات، والحكم على سجع وتقفية الكلمات، وتقسيم الجمل إلى كلمات، ويتحقق هذا عن طريق تعريض التلميذ للغة استماعًا، وانتاجًا. ويمكن كذلك تحديد خطوات الاستر اتيجية بالترنيب كما يلي: 
أثر برنامج قائم على الوعي الصوتي في تنمية مهارات القراعة الجهرية لاى التلاميذ ضعاف السمع بالمرحلة الإبتدائية

- يعرض المعلم على التلاميذ الحروف الهجائية بالحركات، مع صورة لكلمة تبدأ بصوت الابنده

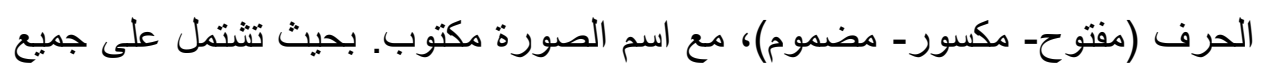

$$
\text { أصوات الحروف الهجائية. }
$$

- يقدم المعلم تحليلاً لغوياً للحروف الهجائية بالصوت والصورة، مع إعطاء صورة سمعية منطوقة لمزج أصوات الحروف، ودعم تقدم التلميذ في نطق مجموعات متز ايدة من الكلمات.

- يناقش المعلم التلاميذ في أصوات الحروف وأوجه التشابه والاختلاف بين أصوات الحروف ونطقها، والأنماط البصرية (شكل الحروف) لها عبر الكلمات . - يستخدم المعلم بعض التكنيكات التي تجعل أصوات الحروف أكثر محسوسية، كأن تمثل الحروف أو المقاطع بمكعبات يستخدمها الطفل في عمليات تقسيم الكلمات إلى أصوات، ومقاطع. - يساعد المعلم التلميذ على إنشاء تر اكيب لكلمات متعددة المقاطع، مع تلوين كل مقطع

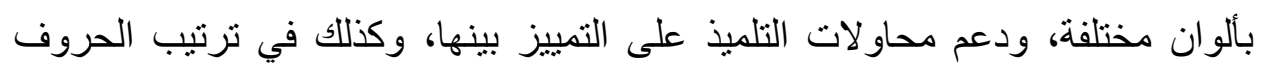
و المقاطع و الكلمات. - ينطق المعلم الكلمات موضع التدريب، مع التأكيد على طريقة النطق، ثم يزواج بين نطق الكلمة وكتابتها. - يقوم التلميذ بنطق الكلمات موضع التدريب، ثم يقر أها بصوت عال. - يقوم التلميذ بإنتاج كلمات على نفس النمط . - يستتتج التلميذ الخصائص التحليلية و التركيبية للكلمة.

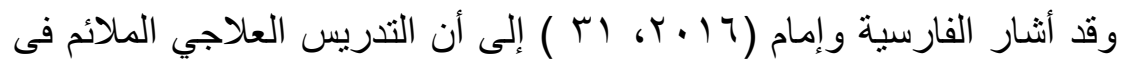
الاستر اتيجيات القائمة على مدخل الوعي الصوتي هو التدريس المباثر القائم على تحليل 
د. حنان محمد فياض

أصوات حروف الكلمات والمزج السمعي، وتقوم عملية تحليل أصوات الحروف

و الكلمات على خمس خطوات كما يلي:

- التركيز على المكونات السمعية أو الصوتية للكلمة.

- تقديم التحليل بالبدء بالحروف، ثم المقاطع، ثم الكلمات، ثم الجمل.

- البدء بكلمات تحتوي على أقل عدد من الأصوات أو الحروف.

- - مذجة عمليات تحليل وتجزئة الكلمات، ومهار ات مزج الحروف وتعزيزها.

- إحداث تكامل بين مهار ات التحليل والدمج في سياقات ذات معني، بالتطبيق على

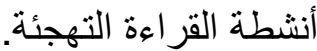

- استخدام الأنشطة في التدريب على الوعي الصوتي التي تعتمد على اللعب و المرح و القصص و الأنانشيد والإيقاع و القافية، وتقديم التعزيز المستمر، و التلاعب المتبادل في الأصوات المرتفعة والمنخفضة، و التصفيق مع المقاطع الصوتية، واستخدام

المكعبات، ولعبة التخمين، حتي ينمو الوعي الصوتي بشكل متكامل.

ويتطلب تنفيذ خطوات استراتيجية الوعي الصوتي أن يقوم كل من المعلم والمتعلم

بعدة أدو ار نوضحها فيما يلي.

ب- أدوار المعلم في الاستراتيجية القائمة على مدخل الوعي الصوتي: - ميقدم المعلم أنشطة القر اءة. - - مبنق المعلم الكلمات موضع الدرس.

- يكون المعلم النموذج المقتدي به للخصائص الصوتية الممبزة لكل صوت من وقف

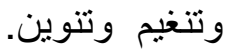

- يكون المعلم المر اقب و القائم بالملاحظة، للتأكد من فهم المتعلم ووعيه لما يفعل. - - تقويم الأداء النهائي للتحقق من فاعلية الاستر اتيجية. 
أثر برنامج قائم على الوعي الصوتي في تنمية مهارات القراءة الجهرية لاى التلاميذ ضعاف السمع بالمرحلة الإبتدائية

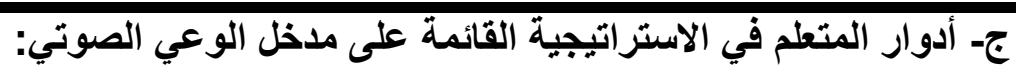

$$
\begin{aligned}
& \text { - يستمع إلى الكلمات موضع التدريب. }
\end{aligned}
$$

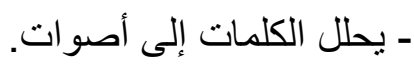

$$
\begin{aligned}
& \text { - يحلل الكلمات إلى مقاطع. }
\end{aligned}
$$

- مر اعاة الخصائص الصوتية المميزة لكل صوت اقتداء بمعلمه.

$$
\text { إجراءات البحث }
$$

يهذف هذا المحور إلى بناء برنامج قائم على مدخل الوعي الصوتي، وتحديد

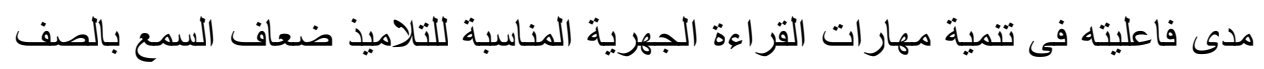
الثاني و الثالث الابتدائي. ولتحقيق هذه الأهدف تتنتاول الدراسة ما يلىى:

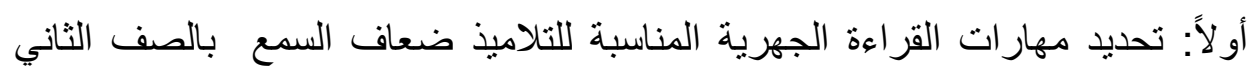

$$
\text { و الثنالث الابتدائي. }
$$

ثانياً: تحديد معايير بناء برنامج قائم على الوعي الصوتى لدى التلاميذ ضعاف السمع

$$
\text { بالصف الثاني والثالث الابتدائي. }
$$

ثالثاً: برنامج القر اءة الجهرية القائم على مدخل الوعي الصوني. رابعاً: التطبيق الميداني للبرنامج. بامج خامسًا: نتائج البحث. سادساً : توصيات البحث ومقترحاته. لبات وفيما يلى تفصيل القول فيما سبق. بوسيات. 


\section{د. حنان محمد فياض}

\section{أولاً: تحديد مهارات القراءة الجهرية المناسبة للتلاميذ ضعاف السمع بالصف الثاني \\ والثالث الابتدائي: - n}

تم تحديد بعض مهار ات القراءة الجهرية المناسبة للتناميذ ضعاف السمع بالصف الثاني و الثالث الابتدائي، وذلك من خلال الدراسات السابقة و الأدبيات التي تناولت مهارات القراءة الجهرية لاى التلاميذ ضعاف السمع بالمرحلة الابتدائية، ومن خلال دراسة أهداف

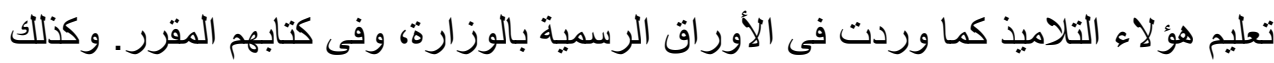
تم تحديد بعض هذه المهارات من خلال دراسة واقع ومشكلات تعليم القراءة الجهرية

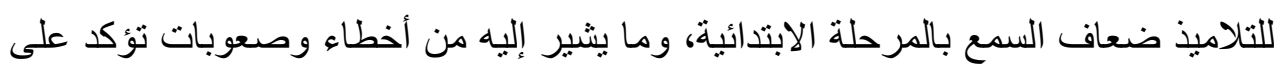
أهمية تنمية مهارات بعينها، ثم وضعت مهارات القراءة الجهرية في فيائمة مبلئية وعُرضت على مجموعة من المحكمين( ملحق رقم ()؛ للتعرف على آرائهم حول مدى بهى مناسبة تلك المهار ات للتلاميذ ضعاف السمع، وسلامة الصياغة اللغوية لها، وتحديد درجة أهميتها بالنسبة للتلاميذ ضعاف السمع موضع البحث. وقد أبدى المحكمون آراءهم في ونه قائمة المهار ات، وبناءً عليها تم إجر اء التعديلات التالية: أ- تعديل صياغة مهارة " تكوين كلمات من الحروف" إلى "تنظيم الحروف في لئهئ

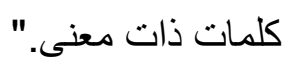

$$
\text { ب- إضافة بعض المهار ات: (التنوين) في مهارة التعرف. }
$$

وقامت الباحثة بإجر اء التعديلات التي أنثار إلبها المحكمون، كما قامت بحساب الوزن

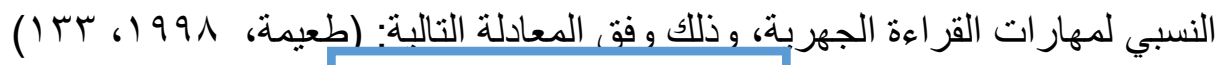

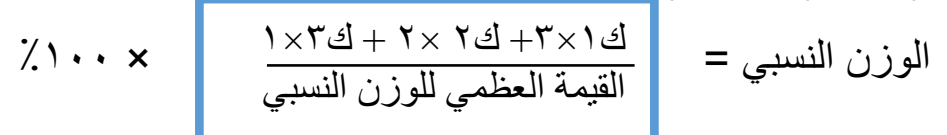

حيث إن القيمة العظمى للوزن النسبي للمهارة = عدد المحكمين (• () × ؟ = • ب 
أثر برنامج قائم على الوعي الصوتي في تنمية مهارات القراعة الجهرية لاى التلاميذ ضعاف السمع بالمرحلة الإبتدائية

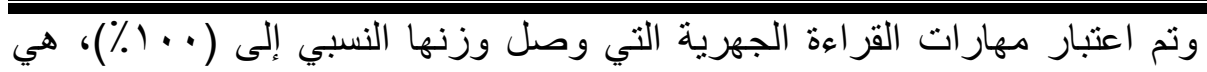
مهار ات مناسبة وذات أهمية لتلاميذ الصف الثاني و الثالث، وما دون هذه النسبة، فقد تم حذفها باعتبار ها لا تمثل أهمية للتناميذ. وبذلك أصبحت قائمة مهارات القراءة الجهرية المناسبة للتلاميذ ضعاف السمع بالصف الثاني والثالث الابتدائي هي المهارات التي حصلت على نسبة . . 1 ٪ من اتفاق المحكمين على أهميتها للتلاميذ. وهذه المهار ات، هي: مهارة التعرف: التعرف على رموز الأصوات والربط بين الصوت والرمز، من خلال توظيف مهارتي التمييز السمعي والبصري ومهارة الذاكرة للربط بين المعطيات البصرية و السمعية للتعرف على المهي الأصو ات و المقاطع و الكلمات و الجمل. ـ التعرف على الحروف بسر عة مناسبة. ـ التمييز بين الحروف المتشابهة صونتاً. ـ التمييز بين الحروف المتشابهة شكلاً. ـ التمييز بين الكلمات المتنشابهة شكلاً. ـ التمييز بين حركات التتوين (تنوين القتح- تنوين الضم- تنوين الكسر). ـ التمييز بين حروف المد قراءة.

مهارة النطق الصحيح : نطق الأصوات نطقاً صحيحاً من حيث المخرج- التمبيز بالنطق بين الأصو ات المتشابهة ـ نطق الحركات نطقاً دقيقاً. - ينطق أصوات الحروف نطقًا صحيحًا. - ينطق أصوات الحروف المنتابهة في المخرج نطقًا صحيحًا. - ينطق أصوات الحروف بحركاتها الثلاث. 


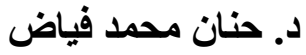

- ينطق أصوت حروف المد نطقًا صحيحًا.

- ينطق اللام القمرية و الثمسية نطقًا صحيحًا.

- ينطق كلمات مكونة من حرفين فأكثر.

مهارة القهر: القدرة على تحليل الكلمات والجمل، وتوليد عدد كبير من البدائل أو المر ادفات أو الأفكار، و واستنتاج المعنى من السياق.

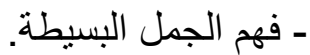

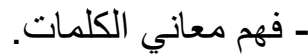

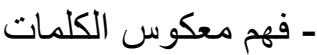

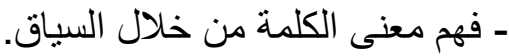

ـ الإجابة المناسبة عن الأسئلة.

ـ تنظيم الكلمات في جمل ذات معني.

ـ تنظيم الحروف في كلمات ذات معني.

- فهم أحداث قصة قصيرة.

ثانيًا: تحديد معايير بناء برنامج قائم على الوعي الصوتى لاى التلاميذ ضعاف السمع بالصف الثاني والثالث الابتائي:

في ضوء التناول السابق للإطار النظرى للاراسة) خصائص التلاميذ ضعاف السمع بالمرحلة الابتدائية، والقراءة الجهرية ومهار اتها المناسبة لهم، وأسس مدخل الوعي الصوتي...) تم تحديد معايير بناء كل عنصر من عناصر برنامج القراءة الجهرية القائم على مدخل الوعي الصوتي، وقامت الباحثة وضع هذه المعايير فى استبانة مبدئية، ثم قدمت الاستبانة إلى عدد من المحكمين لإبداء آرائهم حول مدى مناسبة تلك المعايير

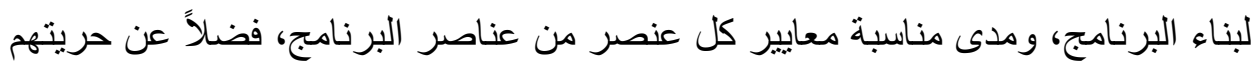
في حذف أو تعديل أو إضافة ما يرونه مناسباً لتلك المعايير، وبناًء على آراء المحكمين تم تعديل قائمة المعايير لتصبح فى صورتها النهاية كما يلي: 
أثر برنامج قائم على الوعي الصوتي في تنمية مهارات القراعة الجهرية لاى التلاميذ ضعاف السمع بالمرحلة الإبتدائية

$$
\begin{aligned}
& \text { أـ المعاييز الخاصة بالأهداف: } \\
& \text { ينبغي أن يُر اعي فى أهداف البرنامج أن: } \\
& \text { - يتوفر في صياغتها شروط الهدف الجيد. }
\end{aligned}
$$

ـ تتسم بالمرونة بحيث تستو عب الفروق الفردية بين التلاميذ ضعاف السمع. ـ تركز الأهداف على تعليم القر اءة الجهرية للتلاميذ باستخدام التمييز السمعي والبصرى. ـ تركز الأهداف على معالجة الصعوبات القرائية والهجائية التي يعاني منها التلاميذ ضعاف السمع بالمرحلة الابتدائية. ـ تكون الأهداف مثتوعة بين أهداف عامة للبرنامج، وأهداف خاصة لكل درس على حدة. ـ تتناسب الأهداف مع المستوى اللغوى للتلاميذ ضعاف السسمع بالمرحلة الابتدائية. - تشمل الأهداف مهارات القر اهة الجهرية موضع البحث. ـ تتدرج الأهداف ـ من حيث تركيز ها على المهارات ـ من الأسهل إلى الأصعب. ب- معايير خاصة بمحتوى البرنامج: ينبغي أن يُر اعى فى اختيار محتوى البرنامج وتتظيمه أن:

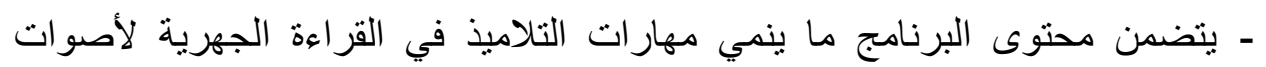
الحروف الهجائية بالحركات. - تتناسب صياغة المحتوى مع الخصائص اللغوية للتناميذ ذوب ضعاف السمع بحيث تكون على مستوى أصوات الحروف، ثم التدرج إلى مستوى الكلمة ثم الجملة ثم القصة القصبرة. - يُنظم محتوى البرنامج في صورة وحدات، بحيث تضم كل وحدة عدداً من الدروس التعليمية. - يُنظيم محتوى البرنامج فى تتابع وتكامل واستمر ار للمعلومات، و المهارات الهجائية و الخبرات التعليمية. 


\section{د. حنان محمد فياض}

- يُرتب محتوى البرنامج ترنيباً منطقياً من البسيط إلى المركب، ومن السهل إلى الصعب.

- يُنظيم المحتوى على هيئة أنشطة تعليمية. - يتضمن المحتوى تعليم التلميذ تنظيم المعرفة بالكلمة داخل الذاكرة طويلة المدى من خلال التمثيل الذهني للمعلومة. ـ تُنظم أنشطة المحتوى وفقاً لمهارت الوعي الصوتي (تحليل أصوات الحروف - تقسيم الكلمات إلي أصوات - تقسيم الكلمات إلى مقاطع ـ مزج الأصوات ـ سجع وتقفية الكلمات - تقسيم الجمل إلى كلمات) ـ تتنوع الأنتطة المقدمة بالمحتوي بحيث تتناسب مع ميول وقدرات كل تلميذ، والتركيز بصورة مباشرة على نطق أصوات الحروف نطقاً صحيحاً. - يتضمن المحتوى أنشطة تسمح للتلاميذ بالتوسع في ممارسة المهارات القرائية المكتسبة

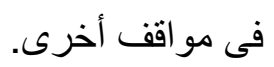

- يتضمن المحتوي تنويع في الأنشطة الفردية و الجماعية. ـ تُنظم أنشطة المحتوى بشكل يساعد على تعلم التلاميذ فى مجموعات.

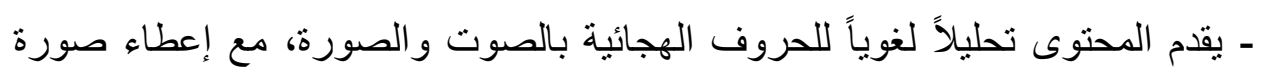

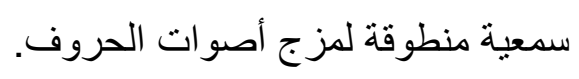
- يتضمن المحتوي التدريب المتكرر على المهارة حتي يتم اتقانها. - يتبني المحتوي وسائل من شأنها الحد من القلق والخوف وزيادة الثقة بالنفس أثناء القر اعة الجهرية.

- يتسلسل المحتوى نسلسلاً منطقيًا وسيكولوجيًا. ـ تُنظم الصور و الأشكال و الرسومات في الأماكن المناسبة لمحتوي البرنامج.

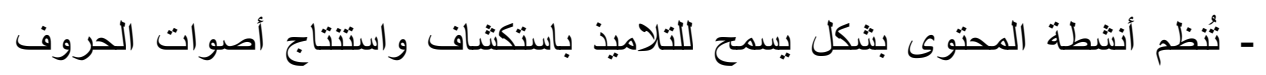
الهجائية. 
أثر برنامج قائم على الوعي الصوتي في تنمية مهارات القراعة الجهرية لاى التلاميذ ضعاف السمع بالمرحلة الإبتدائية

- يُصاغ محتوي البرنامج بأسلوب شيق، بعيداً عن التكرارات والحشو اللغوي والبعد عن بالبه

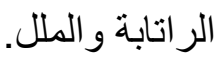

ج- المعاييز الخاصة باسنراتيجية تدريس البرنامج: ينبغي أن تتوفر فى استراتيجية تدريس البرنامج: ـ استخدام أساليب وفنيات تساعد في تنمية المهارات اللغوية، مثل النمذجة، والمحاكاة، و التكرار، تأهيل الكلام من جديد.

ـ التركيز على التلميذ ليكون محوراً للعملية التعليمية، وله دور فعال فى إنجاز ها. ـ التدريس المباثر لما يواجهه التلاميذ من صعوبات فى مهارات القراءة الجهرية، وخاصة تنمية قدرة التلاميذ على تمييز أصوات الحروف الهجائية. ـ تحفيز التلاميذ على التفاعل فى الموقف التعليمى بتو افر الجاذبية فيها. ـ التركيز على خبر ات التلاميذ السابقة، والاعتماد عليها في تقديم الخبرة الجديدة. ـ إتاحة الفرصة الكافية أمام التلاميذ للتدرب و المران. ـ تعويد المتعلم على الاستماع لكلمات تراعي فيها التنويعات الصوتية لكل صوت حرف، مع التأكيد على تقديمها بصورة صحيحة مع مر اعاة التنوعات الصوتية للحرف الواحد، ووروده في مواضع مختلفة من الكلمة. ـ ارتباط الخبر ات والأنشطة المقدمة بتوظيف البقايا السمعية للتلاميذ ضعاف السمع. ـ الربط بين صوت الحرف ورمز الحرف من منطلق التأكيد على المبدأ الأبجدي. ـ تجنب تجريد الصوت أو الرمز لأن خصائصة ليست ملازمة له، و إنما هي مكتسبة من خلال موقعه في الكلمة، و علاقته بالأصوات الأخرى. - تدريب المتعلم على نطق المقطع واعتماده كأساس لتحليل الكلمة، والتعامل معها، وربطها بغير ها. 


\section{د. حنان محمد فياض}

- التركيز على زيادة انتباه القارئ لكل حرف في الكلمة، مما يتفق مع طبيعة عملية

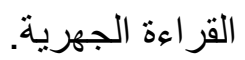

- قصر الفترة الزمنية للتدريس؛ لأن التلاميذ ضعاف السمع لا يستطيعون التركيز لفتر ات طويلة. ـ تفعيل دور الأسرة في المشاركة الفعالة لتدريب وتأهيل التلاميذ ضعاف السمع. ـ مر اعاة التنوع في طر ائق التدريس، وكذلك الوسائل العليمية بما يضمن تحقق الأهداف ويخدم المحتوي في البرنامج التدريبي المقترح. د- معايير خاصة بتقويم البرنامج: ينبغي أن بر اعى فى تقويم البرنامج ما يلي: لئي ـ ملازمة التقويم لكل مرحلة من مراحل تدريس البرنامج، وعدم الاقتصار عليه فيى لئ نهاية الدرس. ـ التركيز على معالجة الأخطاء الهجائية الثنائعة لدى التلاميذ. ـ التركيز على تصحيح نطق أصوات الحروف الهجائية الخاطئة التلاميذ فى القراءة الجهرية.

ـ شمولية التقويم لجميع جو انب الدرس المر اد تقييمه.

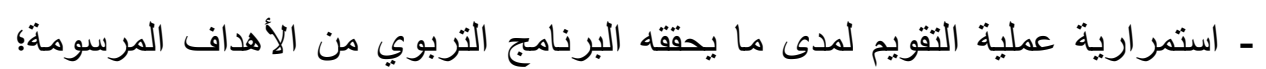
حتي يتسني تصحيح مسار عملية التعلم أولًا بأول. - التدرج من السهل إلى الصعب. ـ تعدد وتنوع الوسائل و الأساليب المستخدمة في التقويم . ـ تقديم التغذية الراجعة فورية ليعرف المتعلم طبيعة الأخطاء القرائية (أخطاء النطق) التي ارتكبها ويصححها. - الاتساق بين التقويم و الأهداف المر اد تحقيقها . ـ التعاون بين المعلم وأولياء الأمور و التلمبذ فى تنفيذ عملية التقويم. 
أثر برنامج قائم على الوعي الصوتي في تنمية مهارات القراعة الجهرية لاى التلاميذ ضعاف السمع بالمرحلة الإبتدائية

ـ تحديد جوانب القوة والضعف في أداء التلاميذ بقصد تعزيز جوانب القوة والإفادة منها في علاج جو انب الضعف.

ـ التمييز بين مستويات الأداء المختلفة للتنلاميذ، و الكثف عن الفروق الفردية و القدرات المتنو عة لاى لتلاميذ. - نرك أثر طيب في نفوس التنلاميذ. - إسهام التقويم في تحسين القراءة الجهرية، وفى إحداث تغييرات إيجابية في جميع مهار ات القر اعة الجهرية لصالح التلاميذ. ـ اقتصادية التقويم في الوقت والجهد حتي لا يصاب التلاميذ بالملل. ثالثاً: برنامج القراعة الجهرية القائم على مدخل الوعى الصوتي: في ضوء المعايير السابقة تم بناء برنامج القراءة الجهرية القائم على مدخل الوعي الصوتي (ملحق رقم 0)، والذى سيقدم للتلاميذ ضعاف السمع بالصف الثاني والثالث الابتدائي، وقد جاء البرنامج على الصورة التالية :

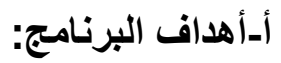
تحدد الهدف العام للبرنامج فى تنمية مهارات القراءة الجهرية المناسبة للتلاميذ ضعاف السمع بالصف الثاني و الثالث الابتدائي. أما عن الأهداف الخاصة للبرنامج فيتوقع فى نهاية البرنامج أن يكون التلميذ قادرًا على أن: - يتقن أصوات الحروف الهجائية بالحركات من (أ- ذ) - يتقن أصوات الحروف الهجائية بالحركات من (ر- غ غ) - يتقن أصوات الحروف الهجائية بالحركات من (ف - ي) - يميز صوت الحرف الأول من الكلمة. - يميز صوت الحرف الأوسط من الكلمة. - يميز صوت الحرف الأخير من الكلمة. 


\section{د. دنان محمد فياض}

- يميز بين أصوات الحروف المتشابهة صونًا.

- يميز بين أصوات الحروف المتشابهة شكلًا. - يقسم الكلمات إلى أصوات (الكلمة المكونة من صوتين إلى ثناث أصو ات). - يقسم الكلمات إلى أصوات (الكلمة المكونة من أربع أصوات إلى خمس أصوات).

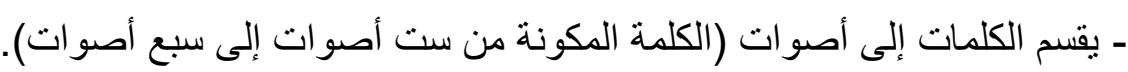
- يقسم الكلمات إلى مقاطع (مقطعين). - يقسم الكلمات إلى مقاطع (ثلاثة مقاطع). - يتعرف على أنواع التنوين. - يميز بين أنواع التنوين. ـ يتعرف على حروف المد. - ينطق حروف المد نطق صحيح. - يتعرف على اللام الثمسية و القمرية. - ينطق اللام القمرية والثمسية نطق صحيح. - ينظيم الحروف في كلمات ذات معني. - يتمكن من تنظيم الحروف في كلمات ذات معني. - يتمكن من مزج المقاطع لتكوين كلمات. - يتعرف على سجع وتقفية الكلمات. - يتمكن من النطق الصحيح لكلمات لها نفس القافية أو النغمة. ـ يتمكن التلميذ سجع وتققية الكلمات.

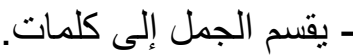
- يتمكن من تنظيم الكلمات في جمل ذات معني. - يفهم أحداث قصة قصيرة. - يقرأ قصة قصيرة قراءة جهرية صحيحة. 
أثر برنامج قائم على الوعي الصوتي في تنمية مهارات القراعة الجهرية لاى التلاميذ ضعاف السمع بالمرحلة الإبتدائية

$$
\text { - بلخص ما تم إنجازه من أهداف البرنامج التدريبي. }
$$

تم بناء برنامج الدراسة الحالية بالاعتماد على عديد من المصادر التربوية، وبعض الكتب و السلاسل التعليمية المعدة لتعليم القراءة، وخاصة القراءة الجهرية" لتركيز هذه الكتب على المهار ات الأساسية فى القراءة، والتي يحتاجها التلاميذ عامة وضعاف السمع خاصة. بالإضافة لبعض المصادر المتعلقة بالوعي الصوني وكيفية استخدامه في تحسين مهارت القراءة، وكذلك بعض المصادر الخاصة بالتلاميذ ضعاف السمع بالمرحلة الابتدائية.

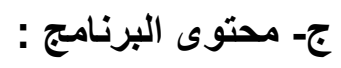
تكون محتوي البرنامج ست وحدات دراسية (ملحق رقم ؟)، وهى : ـ الوحة الأولي: تحليل أصوات الحروف (ثلاثة عشر حصة). الدرس الأول: أصوات الحروف الهجائية بالحركات من (أـ ذ).

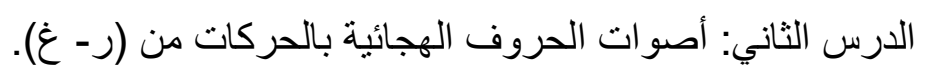
الدرس الثالث: أصوات الحروف الهجائية بالحركات من (ف -بي) الدرس الر ابع: تمييز صوت الحرف الأول بالكلمة. الدرس الخامس: تمييز صوت الحرف الأول بالكلمة. الدرس السادس: تمييز صوت الحرف الأوسط بالكلمة. الدرس السابع: تمييز صوت الحرف الأوسط بالكلمة. الدرس الثامن: تمييز صوت الحرف الأخير بالكلمة. الدرس التاسع: تمييز صوت الحرف الأخير بالكلمة. الدرس العاثرر: تمييز أصو ات الحروف المتشابهة شكلاً. الدرس الحادي عشر: تمييز أصوات الحروف المنشابهة شكلاً. 
د. حنان محمد فياض

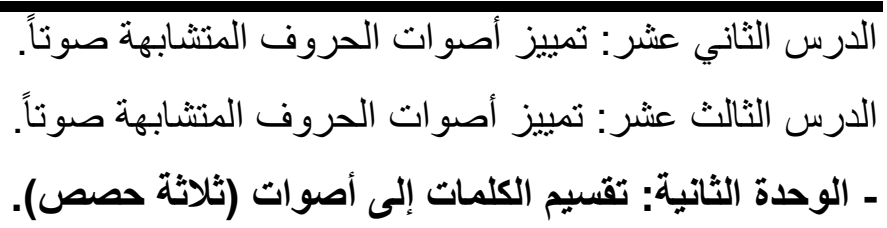

الدرس الرابع عشر: تقسيم الكلمات إلى أصوات (الكلمة المكونة من صوتين إلى ثلاث أصو ات). الدرس الخامس عشر: تقسيم الكلمات إلى أصوات (الكلمة المكونة من أربع أصوات إلى

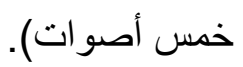
الدرس السادس عشر: تقسيم الكلمات إلى أصوات (الكلمة المكونة من ست أصوات إلى سبع أصوات). الوحدة الثالثة: تقسيم الكلمات إلى مقاطع (سبعة حصص). الدرس السابع عشر: تقيم الكلمات إلى مقاطع . الدرس الثامن عشر : التنوين. الدرس التاسع عثر : التنوين. الدرس العشرون: حروف المد. الدرس الحادي و العشرون: حروف المد. الدرس الثاني و العشرون اللام الثمسية والقمرية. الدرس الثالث و العشرون اللام الثمسية والقمرية. ـ الوحدة الرابعة: مزج الأصوات (ثلاثة حصص). الدرس الرابع و العشرون: تنظيم الحروف في كلمات ذات معني. الدرس الخامس و العشرون: تنظيم الحروف في كلمات ذات معني. الدرس السادس و العشرون: مزج المقاطع لتكوين كلمات. ـ الوحدة الخامسة: سجع وتقفية الكلمات (ثلاثة حصص). الدرس السابع و العشرون: سجع وتققية الكلمات. 
أثر برنامج قائم على الوعي الصوتي في تنمية مهارات القراعة الجهرية لاى التلاميذ ضعاف السمع بالمرحلة الإبتدائية

الارس: الثامن والعشرون. سجع وتقفية الكلمات. الدرس التاسع و العشرون: سجع وتققية الكلمات. ـ الوحدة السادسة: تقسيم الجمل إلى كلمات (سبعة حصص). الدرس الثلاثون: تقسيم الجمل إلى كلمات الدرس الحادي و الثلاثون: تقسيم الجمل إلى كلمات. الدرس الثاني و الثلاثون: تنظيم الكلمات في جمل ذات معني. الدرس الثالث و الثناثون: تنظيم الكلمات في جمل ذات معني. الدرس الر ابع و الثثلاثون: فهم أحداث قصة قصيرة. الدرس الخامس و الثناثثن: فهم أحداث قصة قصيرة. الدرس السادس و الثنلاثون: الختام. وقد تم تنظيم المهار التدرج بتناول المهارات على مستوى الكلمة، ثم الجملة، ثم القصة القصيرة. كما تمت صباغة الدروس على هيئة أنشطة تعليمية، حيث يشتمل كل درس على : ـ أنشطة لجذب انتباه التلاميذ وتحفيز هم للارس المقدم. ـ أنشطة لاستكثاف مهار ات القراءة الجهرية المقدمة باستخدام الوعي الصوتي ومن ثم اقتر اح التفسيرات و الحلول. ـ أنشطة للتوسع وتعميم ما تعلموه على مو اقف جديدة مشابهة. - أنشطة للتقويم.

\section{د- استراتيجية تدريس البرنامج:}

تم تدريس هذا البرنامج باستر اتيجية تدريس قائمة على الوعي الصوتي لتنمية

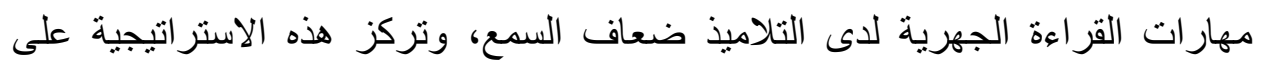
تعليم التلاميذ ربط الحروف بالأصوات، والمنهج الصوتي في الو اقع أسلوب من أساليب 
د. دنان محمد فياض

تعرف الكلمات لا يصبح منهجاً تعليمياً إلا من خلال التأكيد الشديد على نطق أصوات الحروف، ومن خلال استعمال القواعد الصوتية يتعلم التلاميذ ربط الصوت الصحيح للحروف بكل جزء من أحزاء الكلمة، والتعرف على الكلمات ونطقها، ويفترض معلموا المنهج الصوتي أن التلاميذ يعرفون كلمات معينة من خلال سماعها. ويبدأ تعليم الأصوات في هذه المرحلة لمساعدة التلاميذ على تمبيز الكلمات الجديدة، وبدراسة الأصوات وأشكالها الكتابية يتعلم التلميذ ربط الصوت الصحيح بكل جزء من الكلمة، ويميز نطق الكلمات، ثُ التدرج لنطق الجمل البسيطة، ثم التدرج لنطق الجمل الأكثر تعقيدأ، ثم التدرج لنطق عدة جمل لتكوين قصة قصيرة.

\section{وقد مر تدريس كل درس بالخطوات التالية:}

ه تحديد أهداف الدرس: أى تحديد لما يتوقع أن يكون التلميذ قادراً عليه مع نهاية الدرس. ه التمهيد للدرس: ويتم من خلال مجموعة الاداءات التي بقوم بها المعلم بقصد إعداد التلاميذ للارس بحيث يكونوا في حالة ذهنية أكثر استعدادا للتركيز وجذب انتباههم نحو موضوع الدرس من خلال عرض مجموعة من الصور واللوح الورقية، أو استخدام الألعاب والألغاز، أو استعرض الواجب المنزلي، أو الأسئلة والأمثلة والأنشطة التي يعرف المعلم بأن تلاميذه على صله بها وتتصل بخبراتهم. يقدم المعلم تحليلاً لغوياً للحروف الهجائية بالصوت والصورة، مع إعطاء صورة سمعية منطوقة لمز ج أصوات الحروف، ودعم تقدم التلميذ في نطق مجمو عات متز ايدة من الكلمات. • يناقش المعلم التلاميذ في أصوات الحروف وأوجه التشنابه والاختلاف بين أصوات الحروف ونطقها، و الأنماط البصرية (شكل الحروف) لها عبر الكلمات.

• يساعد المعلم التلمبذ على إنشاء تر اكيب لكلمات متعددة المقاطع، مع تلوين كل مقطع بألوان مختلفة، ودعم محاولات التلميذ على التمبيز بينها، وكذللك في ترتيب الحروف

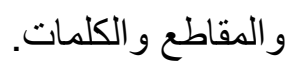

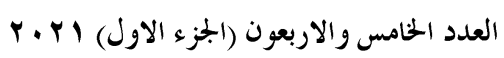

(451)

مجلة كلية التربية- جامعة عين شمس 
أثر برنامج قائم على الوعي الصوتي في تنمية مهارات القراعة الجهرية لاى التلاميذ ضعاف السمع بالمرحلة الإبتدائية

• ينطق المعلم الكلمات موضع التدريب، مع التأكيد على طريقة النطق، ثم يزواج بين نطق لإنئل الكلمة وكتابتها.

• يقوم التلميذ بنطق الكلمات موضع التنريب، ثم يقر أها بصوت عال. • يقوم التلميذ بإنتاج كلمات على نفس النمط . ل • يستتنج التلميذ الخصائص التحليلية و التركيبية للكلمة. • يكون المعلم النموذج المقتدي به للخصائص الصوتية المميزة لكل صوت من تنوين وتتغيم. يقوم المعلم بتقويم التلاميذ فى كل مرحلة من المراحل السابقة بغية تصحيح

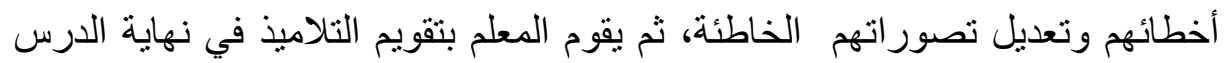
تقويماً نهائياً. • يكون المعلم المر اقب و القائم بالملاحظة، للتأكد من فهم التلاميذ وو عيهم لما يفعلون.

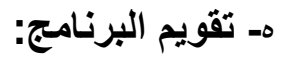
نم تقويم فعالية هذا البرنامج، وكذلك التحقق من استمرار تأثثره من خلال أربعة مستويات على النحو التالي: - ماتم

التقويم القبلي: عن طريق البحث والاطلاع و إضافة التعديلات اللازمة على الحصص وفاعليات

البرنامج في ضوء نتائج الاختبار ات القبلية، وذللك قبل التطبيق. التقويم المستمر: تقويم البرنامج أثناء التطبيق من خلال إجراء تقويم في نهاية كل من حصص البرنامج، للوقوف على مدى استفادة التلاميذ من أنشطة وفاعليات الحصة، وتحديد النقاط التي تحتاج إلى تعديلات لتتناسب مع التطبيق العملي للدروس و إجر اءات البرنامج، والتي لم تتضح أثناء

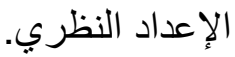




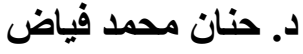

• التقويم البعدي: بعد الانتهاء من أنشطة البرنامج التدريبي يعاد تطبيق الأدوات و المقاييس المستخدمة في الدراسة على عينة الدراسة للكثف عن فاعلية

البرنامج لتنمية بعض مهارات القراءة الجهرية (التعرف - النطق الصحيح الفهم) لدى التلاميذ ضعاف السمع المشاركين فيه. التقويم التتبعى: حيث يتم تطبيق نفس الأدوات و المقاييس المستخدمة بعد مرور شهر من انتهاء البرنامج، على عينة الدراسة للوقوف على مدى احتفاظ التلاميذ التهديذ بما تعلموه وتدربو ا عليه أثناء حصص البرنامج.

رابعاً: التطبيق الميدانى للبرنامج:

تم التجريب الميداني للبرنامج وفقاً للإجر اءات التالية: ا-بناء اختبار مهارات القراءة الجهرية لاى التلاميذ ضعاف السمع بالمرحلة الابتدائية.

مر بناء الاختبار بالخطوات التالية: أ - تحديد الهذف من الاختبار:

تم بناء الاختبار بهدف قياس مستوى التلاميذ ضعاف السمع بالصف الثاني و الثالث الابتدائي فى مهار ات القراءة الجهرية المناسبة لهم، والتي تضمنتها القائمة المحددة سابقاً. ب ب - محتوى الاختبار. تكون الاختبار من (ع () سؤالاً، لقياس مهار ات القراءة الجهرية، على مستوى

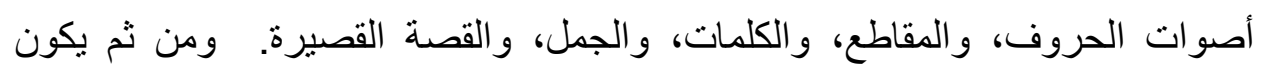
إجمالي درجات الاختبار (107) درجة. وقد نم وضع الاختبار فى صورة مبدئية، وتم عرضها على السادة المحكمين لضبط الاختبار ، وقد تم ضبط الاختبار وفقاً للخطوات التالية: 
أثر برنامج قائم على الوعي الصوتي في تنمية مهارات القراعة الجهرية لاى التلاميذ ضعاف السمع بالمرحلة الإبتدائية

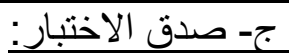

للتحقق من أن الاختبار صالح لقياس مهارات القراءة الجهرية المستهدفة لدى التلاميذ ضعاف السمع بالصف الثاني والثالث الابتدائي تم عرضه على السادة المحكمين لإبداء آرائهم حول مدى مناسبة أسئلة الاختبار لقياس المهارات المستهدفة، ومدى سلامة الصياغة اللغوية للأسئلة. وقد وردت أغلب الآراء مؤكدة إلى سلامة الأسئلة ومناسبتها لقياس المهارات المستهدفة، كما أورد بعض المحكمين عدداً من الملاحظات، قامت الباحثة بتعديل الاختبار في ضوئها، وبذلك أصبح الاختبار فى صورته النهائية (ملحق رقم ؟)

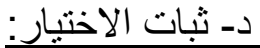

تم التأكد من ثبات الاختبار بطريقة إعادة التطبيق، حيث طبق الاختبار على (•) تلاميذ بالصف الثاني والثالث الابتدائي من مدرسة الأمل للتربية السمعية بالعباسية، ثم أعبد تطبيق الاختبار مرة ثانية عليهم بعد مرور ثلاثة أسابيع، ونم رصد درجات التطبيقين وحساب معامل الثبات، والذى بلغ ائر ، ، ، وهو معامل دال إحصائياً

$$
\text { هـ ـ ـلى ثبات جيد للاختبار. }
$$

تم حساب زمن الاختبار من خلال تحديد متوسط زمن الإجابة لأول تلميذ وآخر تلميذ قاما بالانتهاء من حل الأسئلة وقد تحدد في (0؛ ) دقيقة، وبذا أصبح زمن الاختبار

$$
\text { حو الى (ع § ) دقيقة. }
$$

وبعد الانتهاء من التحقق من صدق الاختبار وثباته، وتحديد زمن الاختبار أصبح الاختبار فى صورته النهائية وقابلاً للتطبيق.

r - بناء مقياس الوعي الصوتي لدى التلاميذ ضعاف السمع بالمرحلة الابتدائية. مر بناء المقياس بالخطوات التالية: 
د. حنان محمد فياض

أ - تحديد الهذف من المقياس:

هدف هذا المقياس إلى قياس الوعي الصوتي لدى التلاميذ، ويتكون من مجموعة من المهام التي تم إعدادها لتشخيص الوعي الصوني لدى التلاميذ ضعاف السمع بالصف الثاني و الثالث الابتدائي. بـ- تحديد محتوى المقياس:

يتكون مقياس الوعي الصوتي من ( • V) مهمة تتناسب مع التلاميذ ضعاف السمع للصف الثاني والثالث الابتدائي، لقياس مهار ات الوعي الصوتي، وقد تم تصميم المقياس في صورة مهام، وقد وزعت المهام على المحاور الستة التالية: م تحليل أصوات الحروف: ويتضمن (Y9) مهمة لتمييز أصوات الحروف، و إدراك التشابه و الاختلاف بينهما وتحديد موقعها في الكلمة المفردة.

م تقسيم الكلمات إلي أصو ات: ويتضمن (T) مهام أن يحدد التلميذ عدد الأصوات للكلمة. O تقسيم الكلمات إلى مقاطع: ويتضمن (0) مهام أن يحدد التلميذ عدد المقاطع الصوتية للكلمة.

م مزج الأصوات: ويتضمن (10 ) مهمة أن يمزج التلميذ الأصوات المنفردة لتكوين كلمات. O مجع وتقفية الكلمات: ويتضمن ( • ( ) مهام ليحدد الكلمات التي لها نفس النغمة. م تقسيم الجمل إلى كلمات: ويتضمن (0) مهام ليحدد التلميذ عدد الكلمات التي تتكون منها

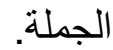
وقد تم وضع المقياس فى صورة مبدئية، وتم عرضه على السادة المحكمين لضبط المقياس، وقد تم ضبط المقياس وفقاً للخطو ات التالية: ج- صدق المقياس: للتحقق من أن المقياس صالح لقياس مهارات الوعي الصوتي المستهدفة لدى التلاميذ ضعاف السمع بالصف الثاني والثالث الابتدائي، تم عرضه على السادة 
أثر برنامج قائم على الوعي الصوتي في تنمية مهارات القراعة الجهرية لاى التلاميذ ضعاف السمع بالمرحلة الإبتدائية

المحكمين لإبداء آرائهم حول مدى مناسبة مفردات المقياس لقياس الوعي الصوتي، ومدى مناسبة المهام لقياس كل بعد من أبعاد المقياس، ومدي مناسبة الصور الواردة في المقياس للصف الثاني والثالث الابتدائي. وقد أشارت أغلب الآراء إلى سلامة المهام ومناسبتها لقياس الوعي الصوتي، كما أورد بعض المحكمين عدداً من الملاحظات حول كيفية تطبيق المقياس، وزيادة بعض الصور والتركيز على أن تكون الصور ملونة، وقامت الباحثة بتعديل المقياس في ضوئها. د- ثبات المقياس:

تم التأكد من ثبات المقياس بطريقة إعادة التطبيق، حيث طبق المقياس على ( • (1) تلاميذ بالصف الثاني والثالث الابتدائي من مدرسة الأمل للتربية السمعية بالعباسية، ثم أعيد تطبيق المقياس مرة ثانية عليهم بعد مرور ثناثة أسابيع، ونم رصد درجات التطبيقين وحساب معامل الثبات، والذى بلغ ائ , · ، و هو معامل دال إحصائياً على ثبات

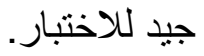
ه- زمن المقياس: تم حساب زمن المقياس من خلال تحديد متوسط زمن الإجابة لأول تلميذ وآخر تلميذ قاما بالاتتهاء من حل الأسئلة وقد تحدد في (• (7) دقيقة، وبذا أصبح زمن الاختبار حوالى ( • ( ) دقيقة.

وبعد الانتهاء من التحقق من صدق المقياس وثباته، وتحديد زمن المقياس -

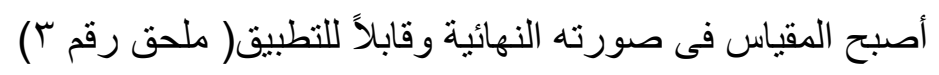




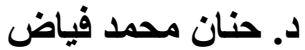

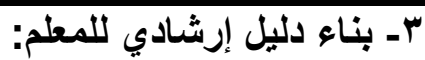

قامت الباحثة بيناء دليل للمعلم؛ لمساعدته فى تدريس برنامج الدراسة القائم على

مدخل الوعي الصوتي لتنمية مهار ات القراءة الجهرية للتلاميذ ضعاف السمع بالمرحلة الابتدائية. وقد تضمن الاليل ما يلى:

- صفحة الغلاف، و المقدمة، ومحتويات الدليل.

ـ الهدف العام و الأهداف الخاصة المرجو تحقيقها من تدريس الوحدة. ـ الخطو ات الإجرائية لاستر اتيجية التدريس المتبعة في تدريس الوحدة. ـ الوسائل و الأنشطة التعليمية المستخدمة في تدريس الوحدة. ـ الخطة الزمنية لتدريس الوحدة. - نموذج لإجر اءات تدريس أحد دروس الوحدة. وقد تم عرض الدليل على مجموعة من المحكمين لإبداء آرائهم حول: مدى وضوح إجر اءات استر اتيجية التدريس، ومدى مناسبة والوسائل و الأنشطة المستخدمة فيها . وقد أبدى المحكمون ملاحظاتهم على الدليل وأكدوا صلاحيته للاستخدام، وقام الباحث بالاستفادة من ملحوظات المحكمين، وإجراء بعض التعديلات فى ضوئها حتى أصبح الدليل فى صورته النهائية (ملحق رقم ع) ع - تحديد التصميم التجريبى للبحث: يستند البحث الحالي على التصميم التجريبى ذي المجموعة الواحدة. ويتم فى هذا التصميم التعرف على أثر برنامج قائم على الوعي الصوتي في تتمية مهارات القراعة الجهرية لاى التلاميذ ضعاف السمع بالصف الثاني والثالث الابتدائي، من خلال الخطوات التالية: ـ تطبيق اختبار القراءة الجهرية على التلاميذ موضع الدر اسة تطبيقًا فبليًا. ـ تطبيق مقياس الوعي الصوتي على التلاميذ موضع الدراسة تطبيقاً قبلياً.

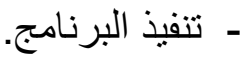

ـ تطبيق اختبار القراءة الجهرية - تطبيقًا بعديًا. 
أثر برنامج قائم على الوعي الصوتي في تنمية مهارات القراعة الجهرية لاى التلاميذ ضعاف السمع بالمرحلة الإبتدائية

$$
\text { - تطبيق مقياس الوعي الصوتي - تطبيقًا بعديًا. }
$$

ـ المقارنة بين نتائج التطبيقين القبلي و البعدي لاختبار مهار ات القراءة الجهرية ومقياس

$$
\text { الوعي الصوتي. }
$$

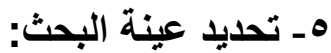

تم اختيار عينة البحث من بين تلاميذ الصف الثاني والثالث الابتدائي بمدرسة

الأمل للتربية السمعية بالعباسية، ممن تتراوح أعمارهم الزمنية بين V- 9 سنوات، بمتوسط عمري ^ سنوات، وقد بلغ عددهم عثرة تلاميذ. وقد اكتفت الدراسة بهذا العدد؛ نظرًا لأن متوسط عدد التلاميذ فى فصول مدارس الأمل للصم وضعاف السمع فى

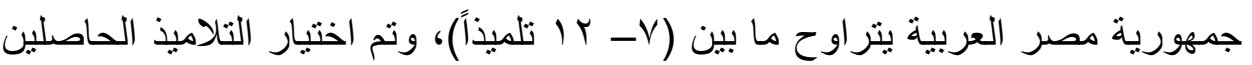
على درجات منخفضة منقاربة فى كل مقياس الوعي الصوتي، واختبار القراءة الجهرية، وتراوحت نسبة الفقد السمعي لدى التلاميذ بين (0ب ـ ـ 0) ديسيبل، ويستخدمون معينات سمعية، و لا يعانون من أية إعاقات إضافية.

צ- تطبيق اختبار مهارات القراعة الجهرية ومقياس الوعي الصوتي قبليًا: تم تطبيق مقياس الوعي الصوتي واختبار مهارات القراءة الجهرية قبليًا على التلاميذ عينة البحث؛ بهدف تحديد مستواهم فى مقياس الوعي الصوتي ومهار ات القراءة الجهرية المستهدفة قبل تنفيذ البرنامج المقترح. وقد روعى فى تطبيق الاختبار والمقياس الاعتبار ات التالية: - أن يتم في مكان هادئ بعيد عن المشتتات. ـ أن يتم التطبيق بشكل فردي لكل تلميذ على حدة. ـ شرح الهدف من هذا المقياس والاختبار، وتعليماته. ـ قر اءة الأسئلة للتلاميذ في أثناء تطبيق . 
د. حنان محمد فياض

وقد تم التطبيق في جلسات منفصلة لكل تلميذ، واستمر هذا التطبيق أسبو عًا كاملاً

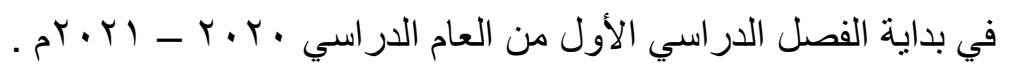

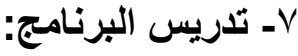

تم تدريس برنامج القراءة الجهرية للتلاميذ ضعاف السمع بالصف الثاني والثالث الابتدائي (عينة الدراسة)، وذلك فى بداية الفصل الدراسي الأول من العام الدراسي

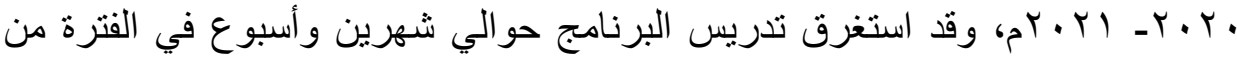

شهر أكتوبر لشهر ديسمبر ·.r.r.r، بواقع (أربع) حصص أسبوعيًا. وقد تم تدريس برنامج القراءة الجهرية المعد لهم، وذلك باستخدام استراتيجية قائمة علي الوعي الصوتي، وقد تطلب التدريس بهذه الاستراتيجية تدريب معلم المجموعة التجريبية على كيفية تتفيذها في تدريس البرنامج، و إمداده بدليل المعلم الموضح للخطوات التفصيلية لكيفية تنفيذ الاستراتيجية فى تدريس دورس وحدات البرنامج.

^ــ تطبيق اختبار مهارات القراعة الجهرية ومقياس الوعي الصوتي بعديًا: نم تطبيق اختبار مهارات القراءة الجهرية ومقياس الوعي الصوتي بعديًا على التلاميذ (عينة البحث) بعد الانتهاء من تطبيق البرنامج؛ بهدف تحديد المستوى الذي وصلوا إليه في مهارات القراءة الجهرية ومقياس الوعي الصوتي، وقد روعي في هذا التطبيق كل ما رُوعِي في التطبيق القبلي، ثم تم رصد درجات التطبيق البعدي، و إجراء المعالجة الإحصائية لدرجات التطبيقين: القبلي و البعدي.

9- التطبيق التبعي لاختبار مهارات القراعة الجهرية ومقياس الوعي الصوتي: بعد أسبوعين من انتهاء التطبيق البعدى لاختبار مهارات القراءة الجهرية ومقياس الوعي الصوتي على التلاميذ عينة الدراسة، تمت إعادة تطبيقه تتبعيًا، ثم تم رصد الدرجات ومعالجتها إحصائيًا وتحليلها لاستخلاص أهم ما تسفر عنه من نتائج. 
أثر برنامج قائم على الوعي الصوتي في تنمية مهارات القراعة الجهرية لاى التلاميذ ضعاف السمع بالمرحلة الإبتدائية

خامسًا: نتائج البحث.

نتائج الفرض الأول: يوجد فرق ذو دلالة إحصائية بين متوسطي رتب درجات مجموعة البحث على مقياس الوعي الصوتي وأبعاده في القياسين القبلي والبعدي لصالح القياس

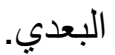

لتحقق من هذا الفرض تمت المقارنة بين متوسطات رتب درجات مجموعة البحث فى القياسين القبلى والبعدى على مقياس الوعي الصوتي للتلاميذ ضعاف السمع (ن= • ( ) عبر استخدام اختبار ويلكسون (Willcoxon)، بعد إيجاد المتوسط الحسابى والانحر اف المعيارى لكل بُعد، الموضح بالجدول التالى:

جدول (1) المتوسط الحسابي والانحراف المعياري لأبعاد مقياس الوعي الصوتي في القياسين القبلي والبعدى

\begin{tabular}{|c|c|c|c|c|}
\hline \multicolumn{2}{|c|}{ القياس البعدى } & \multicolumn{2}{|c|}{ القياس القبلي } & \\
\hline الانحراف & المتوسط & الانحراف & المتوسط & أبعاد مقياس الوعي \\
\hline$r, \Sigma V$. & $1 \wedge, 9$. & $r, 10$. & $\varepsilon, Y$. & تحليل أصوات الحرف \\
\hline . & $r, v$. &., $0 T V$ & $1,0$. & تقتسيم \\
\hline . , हАץ & r,r. &., 01 & $1, \varepsilon$. & تقاطِع \\
\hline $1, v \cdots$ & $1 \cdot, \ldots$ & $1, \Gamma v \cdot$ & $T, 9$. & مزج الأصو ات \\
\hline $1,1,0$ & $7, \wedge$. & . & $r, \ldots$ & سجع وتققية الكلمات \\
\hline., 799 & $r, \tau$. & . , ¿Аץ & $1, r \cdot$ & تقسيم الجمل إلى كلمات \\
\hline
\end{tabular}


د. حنان محمد فياض

جاول (ץ) نتائج اختبار ويلكسون (Willcoxon)

لمجموعة البحث فى القياسين القبلى و البعدى لأبعاد مقياس الوعي الصوتي.

$(1 \cdot=\dot{0})$

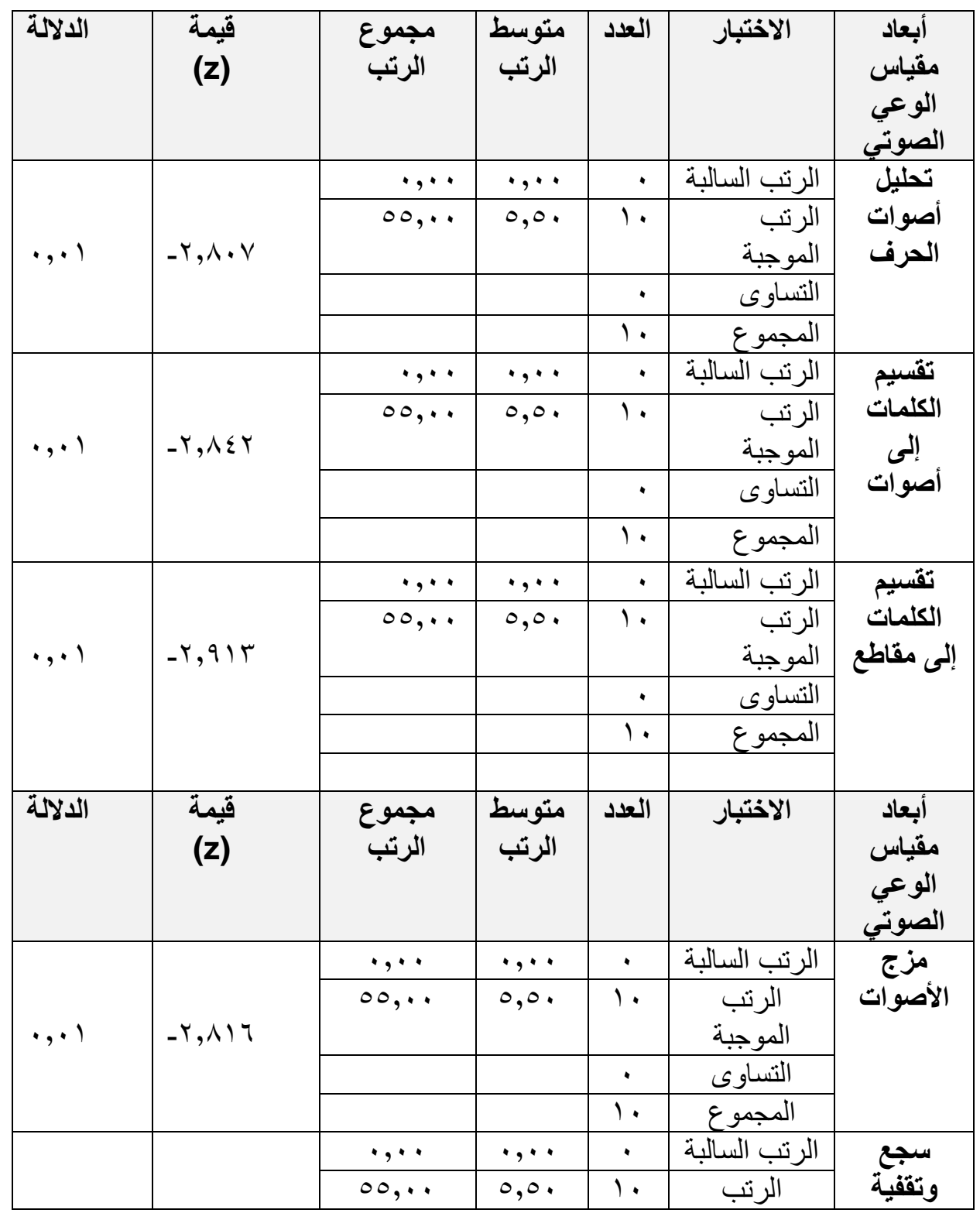

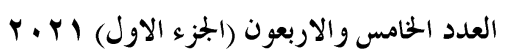

مجلة كلية التربية- جامعة عين شمس (461) 
أثر برنامج قائم على الوعي الصوتي في تنمية مهارات القراعة الجهرية لاى التلاميذ ضعاف السمع بالمرحلة الإبتدائية

\begin{tabular}{|c|c|c|c|c|c|c|}
\hline \multirow[t]{3}{*}{.,$\cdot 1$} & \multirow[t]{3}{*}{$-r, \wedge \leqslant Y$} & & & & الموجبة & \multirow[t]{3}{*}{ الكلمات } \\
\hline & & & & . & التساوى & \\
\hline & & & & 1. & المجموع & \\
\hline \multirow{4}{*}{$\cdot, \cdot 1$} & \multirow{4}{*}{ - } & $\cdot, \cdot$ &,$\cdots$ & · & السالبة & \multirow{4}{*}{ كلمات الجملِ } \\
\hline & & $00, \ldots$ & $0,0$. & 1. & الموجبة & \\
\hline & & & & · & التساوى & \\
\hline & & & & 1. & المجموع & \\
\hline
\end{tabular}

من متوسطات درجاتهم بالقياس القبلى على مقياس الوعي الصوتي، وتؤكد البيانات

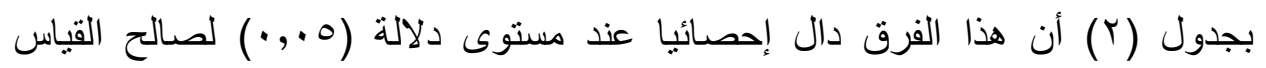
البعدى، فى كل أبعاد مقياس الوعي الصوتي، والدرجة الكلية مقياس الوعي الصوتي،

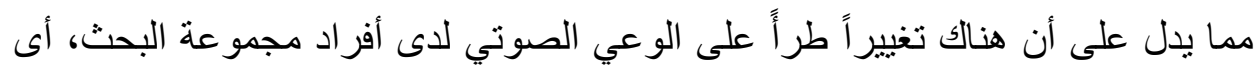
أن البرنامج قد حسن من الوعي الصوتي لدانهم. نتائج الفرض الثاني: يوجد فرق ذو دلالة إحصائية بين متوسطي رثب درجات مجموعة البحث على اختبار مهار ات القراءة الجهرية في القياسين القبلي والبعدي لصالح القياس البعدي.

للتحقق من هذا الفرض تمت المقارنة بين متوسطات رتب درجات مجموعة البحث فى القياسين القبلى والبعدى على اختبار مهار ات القراءة الجهرية للتناميذ ضعاف السمع (ن= • ( ) عبر استخدام اختبار ويلكسون (Willcoxon)، بعد إيجاد المتوسط الحسابي و الانحر اف المعياري لكل بُعد، الموضح بالجدول التالى: 
د. حنان محمد فياض

جذول (ץ) المتوسط الحسابي والاتحراف المعياري لأبعاد اختبار القراءة الجهرية في القياسين القبلي والبعدي

\begin{tabular}{|c|c|c|c|c|}
\hline \multicolumn{2}{|c|}{ القياس البعدى } & \multicolumn{2}{|c|}{ القياس القبلى } & \multirow[b]{2}{*}{ القراغة اختبار } \\
\hline الانحر اف & المتوسط & الانحراف & المتوسط & \\
\hline $7, Y \wedge T$ & $\varepsilon \vee, \Lambda$. & $r, \mid \vee 1$ & Yr,O. & الحروف \\
\hline$\cdot, \lambda r T$ & $0, V$. & $1, . \vee 0$ & T, $\Sigma$. & المقاطع \\
\hline$\varepsilon, 9 \leq 9$ & Tr,T. & r,Tor & IT,r. & الكلمات \\
\hline$\cdot, \nabla \Gamma \wedge$ & 7,1 . &., 017 & r, $\varepsilon$. & الجمل \\
\hline $1,17$. & ר, &., $.77 V$ & $r, \ldots$ & القصة القصبرة \\
\hline
\end{tabular}

جدول ( ) نتائج اختبار ويلكسون (Wilcoxon)

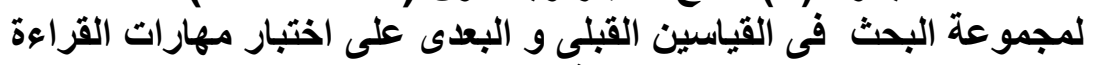

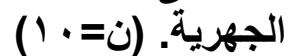

\begin{tabular}{|c|c|c|c|c|c|c|}
\hline الدلالة & $\begin{array}{l}\text { قيمة } \\
\text { (z) }\end{array}$ & الرتبوع & متوسط & العدد & الاختبار & أبعاد اختبار الجراءة \\
\hline \multirow{4}{*}{., .1} & \multirow{4}{*}{$-r, \Lambda, 0$} &,,$\ldots$ &,,$\ldots$ & . & الرالبة & \multirow[t]{4}{*}{ الحروف } \\
\hline & & $00, .$. & 0,0 . & 1. & الموجبة & \\
\hline & & & & $\cdot$ & التساوى & \\
\hline & & & & 1. & المجموع & \\
\hline \multirow{4}{*}{., .1} & \multirow{4}{*}{$-r, \wedge \circ 9$} & $\cdot, \ldots$ & $\cdot, \ldots$ & . & الرالتب & \multirow[t]{4}{*}{ الدقاطع } \\
\hline & & $00, \ldots$ & 0,0 . & 1. & الروتبة & \\
\hline & & & & . & التساوى & \\
\hline & & & & 1. & المجموع & \\
\hline الدلالة & قيمة & الرجموع & متوسط & العدد & الاختبار & مهارات \\
\hline
\end{tabular}

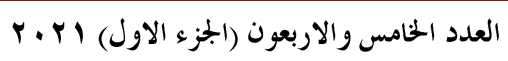

$(463)$

مجلة كلية التربية- جامعة عين شمس 
أثر برنامج قائم على الوعي الصوتي في تنمية مهارات القراعة الجهرية لاى التلاميذ ضعاف السمع بالمرحلة الإبتدائية

\begin{tabular}{|c|c|c|c|c|c|c|}
\hline & & & & & & الجهرية القراعة \\
\hline \multirow{4}{*}{$\cdot,+.1$} & \multirow{4}{*}{$-r, \Lambda \cdot q$} & $\cdot, \ldots$ & $\cdot, \cdot$, & . & السالبة & \multirow[t]{4}{*}{ لكلمات } \\
\hline & & $00, \ldots$ & $0,0$. & 1. & الراتبة & \\
\hline & & & & . & التساوى & \\
\hline & & & & 1. & المجموع & \\
\hline \multirow{4}{*}{.,.,} & \multirow{4}{*}{$-r, q 19$} &,,$\ldots$ & $\cdot, \cdot$, & . & السالبة & \multirow[t]{4}{*}{ الجمل } \\
\hline & & $00, \ldots$ & $0,0$. & 1. & الروتبة & \\
\hline & & & & . & التساوى & \\
\hline & & & & 1. & المجموع & \\
\hline \multirow{4}{*}{., .1} & \multirow{4}{*}{$-r, \wedge r)$} & $\cdot,$. & $\cdot, \cdot$ & . & السالبة & \multirow[t]{4}{*}{ لقصبرة } \\
\hline & & $00, \ldots$ & $0,0$. & 1. & الروتبة & \\
\hline & & & & . & التساوى & \\
\hline & & & & 1. & المجموع & \\
\hline
\end{tabular}

تثير البيانات في جدول (r) أن متوسط درجات مجموعة البحث للقياس البعدي أكبر من متوسطات درجاتهم بالقياس القبلي على اختبار مهارات القراءة الجهرية، وتؤكد البيانات بجدول (ع) أن هذا الفرق دال إحصائياً عند مستوى دلالة (0. . •) لصالح القياس البعدي، فى كل أبعاد مهارات القراءة الجهرية، والدرجة الكلية لاختبار مهار ات

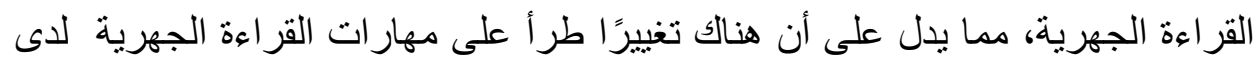
أفر اد مجموعة البحث، أى أن البرنامج قد حسن من مهار ات القر اعة الجهرية لديهر. r- نتائج الفرض الثالث: لايوجد فرق ذو دلالة إحصائية بين منوسطي رتب درجات مجمو عة البحث على مقياس الوعي الصوتي وأبعاده في القياسين البعدى والتتبعي. للتحقق من هذا الفرض تمت المقارنة بين منوسطات رتب درجات مجموعة البحث فى القياسين البعدى و التتبعى على مقياس الوعي الصوتي للتلاميذ ضعاف 
د. حنان محمد فياض

السمع (ن= · ( ) عبر استخدام اختبار ويلكسون (Willcoxon)، بعد ايجاد المتوسط الحسابى و الانحر اف المعيارى لكل بعد، الموضسح بالجدول التالى جدول (0) المتوسط الحسابي والاتحر اف المعياري لأبعاد مقياس الوعي الصوتي في القياسين البعدى والتببعي

\begin{tabular}{|c|c|c|c|c|}
\hline \multicolumn{2}{|c|}{ القياس التتبعى } & \multicolumn{2}{|c|}{ القياس البعدى } & \multirow[b]{2}{*}{ أبعاد مقياس الوعي } \\
\hline الانحراف & المتوسط & الاتحر اف & المتوسط & \\
\hline$r, \wedge \leq T$ & $19,1$. & $r, \Sigma V$. & $11,9$. & تحليل أصوات الحرف \\
\hline $1,07 \pi$ & $\varepsilon, \ldots$ & $\cdot, \wedge Y r$ & $r, v$. & تقصيحت الكلمات إلى \\
\hline ,977 & $r, T$. & ., हरト & $r, r$. & تقسيم الكلمات إلى مقاطع \\
\hline$r, I T r$ & 9,9 . & $1, \vee, \ldots$ & $1, \ldots$ & مزج الأصوات \\
\hline $1, \leq \leqslant 9$ & $7,9$. & 1,1 ro & $\uparrow, \wedge$. & سجع وتقفية الكلمات \\
\hline ח & $\uparrow, \wedge$. &., 799 & ז,T. & تقسيم الجمل إلى كلمات \\
\hline
\end{tabular}

جدول (') نتائج اختبار ويلكسون (Willcoxon)

لمجموعة البحث فى القياسين البعدى و التتبعى على مقياس الوعي الصوتي.

(1.=ن)

\begin{tabular}{|c|c|c|c|c|c|c|c|}
\hline مستوى & الدلالة & $\begin{array}{l}\text { قيمة } \\
\text { (z) }\end{array}$ & مجموع الرتب & متوسط & العدد & الاختبار & أبعاد مقياس الصوعي \\
\hline \multirow[t]{4}{*}{ غير دالة } & \multirow[t]{4}{*}{$\begin{array}{c}\cdot, 7 \wedge \\
\cdot\end{array}$} & \multirow[t]{4}{*}{,$- \varepsilon \mid Y$} & $7, \ldots$ & $r, .$. & $r$ & السالية & \multirow{4}{*}{ أصوات } \\
\hline & & & $9, \ldots$ & $r, \ldots$ & $r$ & الموجبة & \\
\hline & & & & & o & التساوى & \\
\hline & & & & & 1 & المجموع & \\
\hline \multirow[t]{4}{*}{ غير دالة } & \multirow[t]{4}{*}{$\begin{array}{c}., Y_{O} \\
\mathrm{~V}\end{array}$} & \multirow[t]{4}{*}{$\begin{array}{l}1,1 T \\
-\varepsilon\end{array}$} & $\Lambda, \ldots$ & $\varepsilon, \ldots$ & $r$ & الرالبة & \multirow{4}{*}{ أكلمات إلىى } \\
\hline & & & $\begin{array}{c}r \cdot, \cdot \\
\cdot\end{array}$ & $\varepsilon, \ldots$ & 0 & الروجبة & \\
\hline & & & & & $r$ & التساوى & \\
\hline & & & & & 1 & المجموع & \\
\hline مستولة & الدلالة & قيمة & مجموع الرتب & متوسط & العد & الاختبار & أبعاد مقياس \\
\hline غير دالة & $\cdot, r)$ & $1, \ldots$ & $7, \ldots$ & $r, \ldots$ & $r$ & الرتب & \\
\hline
\end{tabular}

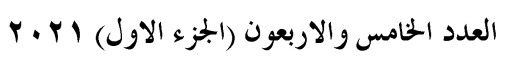

(465)

مجلة كلية التربية- جامعة عين شمس 
أثر برنامج قائم على الوعي الصوتي في تنمية مهارات القراعة الجهرية لاى التلاميذ ضعاف السمع بالمرحلة الإبتدائية

\begin{tabular}{|c|c|c|c|c|c|c|c|}
\hline & V & $-\cdot$ & & & & السالبة & \\
\hline & & & 10, & $r, v_{0}$ & $\varepsilon$ & الروجبة & \multirow{3}{*}{ الكلمات إلىى مقاطع } \\
\hline & & & & & $\varepsilon$ & التساوى & \\
\hline & & & & & t & الدجموع & \\
\hline \multirow[t]{4}{*}{ غير دالة } & \multirow[t]{4}{*}{$\begin{array}{c}., 70 \\
0\end{array}$} & \multirow[t]{4}{*}{, $\{\leqslant V$} & $9, \ldots$ & $r, \ldots$ & $r$ & الرالبة & \multirow[t]{4}{*}{ الأصوات } \\
\hline & & & $7, \ldots$ & $r, \ldots$ & 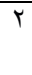 & الموجبة & \\
\hline & & & & & 0 & التساوى & \\
\hline & & & & & $\begin{array}{l}1 \\
\text { t }\end{array}$ & المجموع & \\
\hline \multirow[t]{4}{*}{ غير دالة } & \multirow[t]{4}{*}{.,07£ } & \multirow[t]{4}{*}{$\begin{array}{c}\text { OVV } \\
-\end{array}$} & $r, \ldots$ & $r, \ldots$ & 1 & السالبة & \multirow[t]{4}{*}{ سجع وتقفية } \\
\hline & & & $\varepsilon, \ldots$ & $r, \ldots$ & $r$ & الموجبة & \\
\hline & & & & & $\mathrm{V}$ & التساوى & \\
\hline & & & & & ! & الهجموع & \\
\hline \multirow[t]{4}{*}{ غير دالة } & \multirow[t]{4}{*}{$\begin{array}{c}\cdot, r \\
v\end{array}$} & \multirow[t]{4}{*}{$\begin{array}{r}1, \ldots \\
-\cdot\end{array}$} & $r, 0$. & r,o. & 1 & الرالبة & \multirow[t]{4}{*}{ تقسيم الجمل } \\
\hline & & & $\mathrm{v}, \mathrm{O}$. & r,o. & $r$ & الروجبة & \\
\hline & & & & & 7 & التساوى & \\
\hline & & & & & ! & المجموع & \\
\hline
\end{tabular}

تشير البيانات فى جدول(0) أن هناك تز ايد مضطرد في متوسطات درجات أفر اد العينة على مقياس الوعي الصوتي للأطفال في القياسات البعدية والتتبعية. و تؤكد البيانات بجدول (T) عدم وجود فرق ذو دلالة إحصائية بين منوسط رتب درجات أفراد مجموعة البحث فى القياس البعدى، ومتوسط رتب درجات نفس المجموعة بعد شهر من المتابعة فى القياس التتبعى على أبعاد مقياس الوعي الصوتي، مما يعني استمرار تحسن درجات

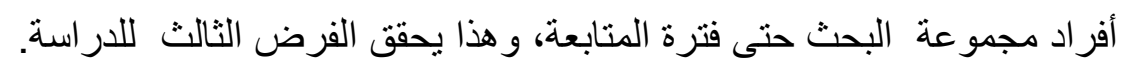
r- نتائج الفرض الرابع: لا يوجد فرق ذو دلالة إحصائية بين متوسطي رثب درجات مجموعة البحث على اختبار مهارات القراءة الجهرية في القياسين البعدى والتتبعي. 
د. دنان محمد فياض

للتحقق من هذا الفرض تمت المقارنة بين متوسطات رتب درجات مجمو عة البحث فى القياسين البعدى والتتبحى على اختبار مهار ات القر اءة الجهرية للتلاميذ ضعاف السمع (ن= • (1) عبر استخدام اختبار ويلكسون (Willcoxon)، بعد ايجاد المتوسط الحسابى و الانحر اف المعيارى لكل بعد، الموضح بالجدول التالى: جدل(V) المتوسط الحساب والانحراف المعياري لأبعاد اختبار مهارات القراءة الجهرية فى القياسين البعدي والتثبعي

\begin{tabular}{|c|c|c|c|c|}
\hline \multicolumn{2}{|c|}{ القياس التتبعى } & \multicolumn{2}{|c|}{ القياس البعدى } & \multirow{2}{*}{ أبعاد اختبار الجهرية } \\
\hline الانحر اف & المتوسط & الانحراف & المتوسط & \\
\hline $7, \leqslant 99$ & $\leq \neg, \vee$. & $7, Y \wedge T$ & $\varepsilon \vee, \wedge$ & الحروف \\
\hline سזr, & $7, \ldots$ & سז, • & $0, V$. & المقاطع \\
\hline $0,1 \wedge V$ & . & $\leq, q \leq q$ & r & الكلمات \\
\hline , VT人 & $7,1$. & ., & 7,1 . & الجمل \\
\hline $1,1 \vee \varepsilon$ & $7, \Sigma$. & 1,17 & . ז. & القصة القصيرة \\
\hline
\end{tabular}

جاول (^) نتائج اختبار ويلكسون (Willcoxon)

لمجموعة البحث فى القياسين البعدى والتتبعى على اختبار مهارات القراءة

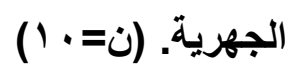

\begin{tabular}{|c|c|c|c|c|c|c|c|}
\hline مستوى & الدلالة & قيمة & الرتبوع & متوسط & العدد & الاختبار & الجهارات الجعار \\
\hline \multirow[t]{4}{*}{ غالة } & \multirow[t]{4}{*}{., 17} & \multirow[t]{4}{*}{$-r V A$} & $I V, \ldots$ & $\varepsilon, Y_{O}$ & $\varepsilon$ & السالبة & \multirow[t]{4}{*}{ لحروف } \\
\hline & & & $\varepsilon, \ldots$ & $r, \ldots$ & r & الموجبة & \\
\hline & & & & & $\varepsilon$ & التساوى & \\
\hline & & & & & 1. & المجموع & \\
\hline \multirow{3}{*}{ غالة } & \multirow[t]{3}{*}{ • } & \multirow[t]{3}{*}{$-1, \ldots$} & $7, \ldots$ & $7, \ldots$ & 1 & الرتب السالبة & \multirow[t]{3}{*}{ المقاطع } \\
\hline & & & $10, \ldots$ & $r, \ldots$ & 0 & الموجبة & \\
\hline & & & & & $\varepsilon$ & التساوى & \\
\hline
\end{tabular}

العدد الخامس والاربعون (الجزء الاول) الr.r.

(467)

مجلة كلية التربية- جامعة عين شمس 
أثر برنامج قائم على الوعي الصوتي في تنمية مهارات القراعة الجهرية لاى التلاميذ ضعاف السمع بالمرحلة الإبتدائية

\begin{tabular}{|c|c|c|c|c|c|c|c|}
\hline & & & & & 1. & المجموع & \\
\hline مستوي الدلاكة & الدلالة & $\begin{array}{l}\text { قيمة } \\
\text { (z) }\end{array}$ & الرجبوع & متوسط & العلد & الاختبار & الجهار البعاد \\
\hline \multirow{4}{*}{ غير } & \multirow{4}{*}{, ro } & \multirow[t]{4}{*}{$-1,1 \Gamma \varepsilon$} & $\Lambda, \ldots$ & Y,TV & $r$ & الرتب السالبة & \multirow{4}{*}{ الكلمات } \\
\hline & & & $r, \ldots$ & $r, \ldots$ & 1 & الموجبة & \\
\hline & & & & & 7 & التساوى & \\
\hline & & & & & 1. & المجموع & \\
\hline \multirow{4}{*}{ غالة } & \multirow[t]{4}{*}{$1, \ldots$} & \multirow{4}{*}{$\cdots$} & $1 ., 0$. & $r, 0$. & $r$ & الرتب السالبة & \multirow[t]{4}{*}{ الجمل } \\
\hline & & & $1 ., 0$. & $r, 0$. & $r$ & الموجبة & \\
\hline & & & & & $\varepsilon$ & التساوى & \\
\hline & & & & & 1. & المجموع & \\
\hline \multirow{4}{*}{ غالة } & \multirow[t]{4}{*}{., 07} & \multirow[t]{4}{*}{$-0, V \mathrm{~V}$} & $r, \ldots$ & $r, \ldots$ & 1 & الرتب السالبة & \multirow{4}{*}{ القصيرة } \\
\hline & & & $\varepsilon, \ldots$ & $r, \ldots$ & $r$ & الموجبة & \\
\hline & & & & & V & التساوى & \\
\hline & & & & & 1. & المجموع & \\
\hline
\end{tabular}

تشير البيانات فى جدول (V) أن هناك تزايد مطرد في منوسطات درجات أفراد العينة على اختبار مهارات القراءة الجهرية في القياسات البعدية والتتبعية. ونؤكد البيانات بجدول (^) عدم وجود فرق دال إحصائيًا بين متوسط رتب درجات أفراد مجموعة البحث فى القياس البعدى، ومتوسط رتب درجات نفس المجموعة بعد شهر من المتابعة فى القياس التتبعى على أبعاد اختبار مهار ات القراءة الجهرية، مما يعني استمرار تحسن درجات أفراد مجموعة البحث حتى فترة المتابعة، وهذا بحقق

$$
\text { الفرض الرابع للار اسة. }
$$

خلاصة القول أن البرنامج المستخدم في الدراسة الحالية؛ بما تضمنه من أساليب وفنيات واستراتيجيات وأنشطة متنوعة كان له دوراً مؤثراً في تنمية مهارات القراءة الجهرية و الوعي الصوتي لاى التلاميذ ضعاف السمع. 
د. حنان محمد فياض

\section{ويمكن تفسير النتائج السابقة بما يلي:}

- طبيعة تدريبات الوعي الصوتي، وارتباط هذه التدريبات بالقدرة على معرفة أماكن إنتاج الأصو ات اللغوية، وكيفية إخر اج الحروف و المقاطع، و الكيفية التي تتشكل فيها هذه الأصوات اللغوية مع بعضها لتكوين الكلمات والجمل، مع القدرة على إدرالك التشابه والاختلاف بين هذه الأصوات سواءً جاءت هذه الأصوات مفردة، أو في الكلمات المختلفة.

- مناسبة محتوى الوحدات (ملحق ع) للقدرات التلاميذ ضعاف السمع بالمرحلة الابتدائية؛ حيث كان المحتوى بسيطاً وكان التركيز فيه على مهار ات القراءة الجهرية، والنطق الصحيح. ـ الاهتمام بفنية الواجب المنزلي كان لها الأثر الكبير في تعميم المهارات التي يكتسبها

$$
\text { التلامبذ ضعاف السمع. }
$$

ـ الاهتمام بفنية التعزيز الفوري كان لها دور كبير في حث التلاميذ ضعاف السمع على اكتساب وتتعلم المهار ات المختلفة. - عرض أنشطة البرنامج للتلاميذ ضعاف السمع بشكل جذاب وبألو ان زاهية تلفت الإنتباه ساهم في إثارة دافعية التلاميذ لمواصلة تعلم مهار ات القراءة الجهرية والوعي الصوتي. - أن استخدام استرايجية قائمة على الوعي الصوتي أسهم في اكساب التلاميذ ضعاف السمع طلاقة ومرونة وسر عة في التعرف على أصوات الحروف و القراءة الجهرية. - تطور قدرة التلاميذ ضعاف السمع في معرفة دلالة الحروف في الكلمات ودلالة الكلمات في الجمل، وذللك بفعل عمليات التدريب التي قام عليها البرنامج و الذي يؤكد على الدور الفعال للتناميذ. ـ كثافة وتنوع التدريبات اللغوية من تدريب على الفهم، والتدريب على نطق مختلف

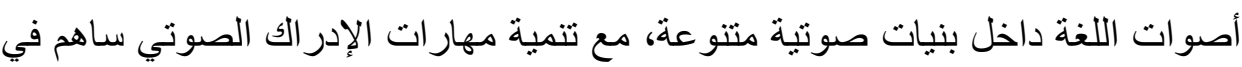


أثر برنامج قائم على الوعي الصوتي في تنمية مهارات القراعة الجهرية لاى التلاميذ ضعاف السمع بالمرحلة الإبتدائية

إيجاد مدخلات لغوية متكاملة ساعدت في بناء مخرجات لغوية سليمة وثابتة الأداء على بلى لإبثله

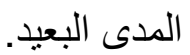

- إن قدرة التلاميذ على تقسيم الكلمة إلى أصوتها اللغوية من خلال تدريبات الوعى الصوتي يقع ضمن مستويات التحليل اللغوي الذي يرتبط بعلاقة قوية ووثيقة مع القدرة على القراءة والنطق الصحيح لأصو ات الحروف و المقاطع و الكلمات. - توظيف الوسائل التعليمية، ومصادر التعلم - كالمقاطع الصوتية المختلفة، واللوحات، و البطاقات التعليمية متنوعة الأشكال، و الرسومات و الصور، و غير ها من الوسائل التي

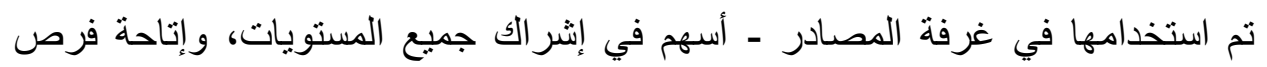
مناسبة أمام التلاميذ للإفادة من الخبرات التعليمية التي تتضمنها تدريبات الوعي الصوتي، وهو ما انعكس إيجاباً على اكتساب مهار ات القر اءة والتقدم فيها. - إن تدريبات الوعي الصوتي تم تنفيذها من خلال توفير مناخ يسود فيه الود والاحترام لمشاعر التلاميذ، والتقبل الإيجابي لهم وتفهم مشكلاتهم، والتعامل معهم بالصبر و الأناة و التدرج في تقديم الخبرات في ضوء مستوياتهم، الأمر الذي أكسب التلاميذ ثقة في الإقبال على القر اءة والتقدم فيها. ـ تنوع وتعدد أساليب التقويم قد أتاح فرصة للتقييم الدقيق لمستوى التناميذ ضعاف السمع، و الوقوف على مو اطن الضعف لليهم ومعالجنها. سادسًا: توصيات البحث ومقترحاته:

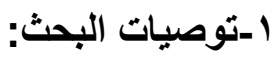

في ضوء نتائج البحث السابقة يمكن تقديم عدد من التوصيات، أهمها: - ضرورة الاهتمام بالوعي الصوتي لدي التلاميذ ضعاف السمع بالمرحلة الابتدائية، و العمل على تنميته وتطويره من خلال برامج تعليمية وخطط منظمة هادفة تسهم في تحسن مستو اه لدي التلاميذ. 
د. دنان محمد فياض

- توظيف تدريبات الوعي الصوتي في تدريس دروس القراءة و الربط الهادف بين أنشطة الوعي الصوتي ومهار اته مع مهار ات القر اءة الجهرية.

- ضرورة الربط الهادف و المنظم بين الوعي الصوتي وبين المهار ات السمعية والقرائية. ـ عقد دورات تدرييية وورش عمل للمعلمين القائمين بتدريس اللغة العربية لذوي الإعاقة السمعية بهدف تدريبهم على كيفية استخدام مهار ات الوعي الصوتي في تدريس اللغة العربية.

ـ الاهتمام بإدراج أنشطة وتدريبات الوعي الصوتي في مناهج اللغة العربية لذوي الاحتياجات الخاصة بالمرحلة الابتدائية. - ضرورة إثر الك الو الدين في البر امج التدريبية المقدمة للتلاميذ ضعاف السمع.

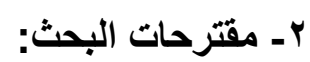

من خلال الدراسة الحالية لوحظ حاجة الميدان لعدد من البحوث المفيدة فى مجال تعليم ذوي الإعاقة السمعية، ومنها:

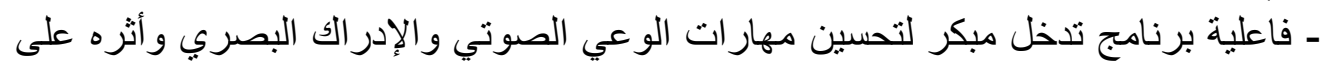

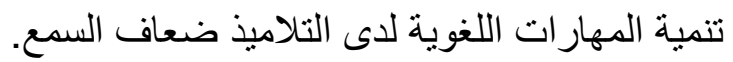
- برنامج تدخل مبكر لتنمية مهارة الوعي الصوتي لإى الأطفال زارعي العارعي القوقعة في مرحلة رياض الأطفال. ـ فاعلية برنامج تدريبي لخفض اضطرل اباتات النطق وتحسين التفاعل الاجتماعي لدي الأطفال ضعاف السمع. - فاعلة برنامج

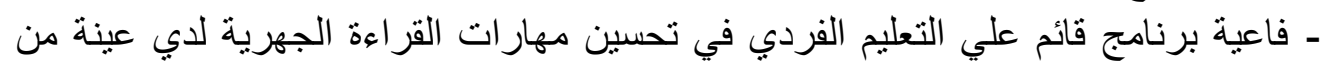
التلاميذ ذوي الإعاقة السمعية بالمرحلة الإبتدائية.

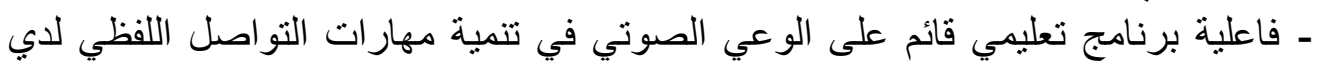
التلاميذ ذوي الإعاقة السمعية.

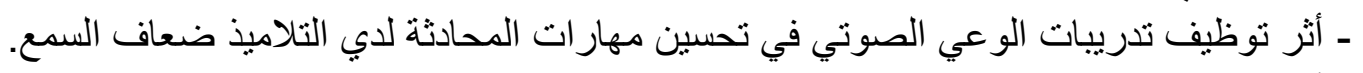

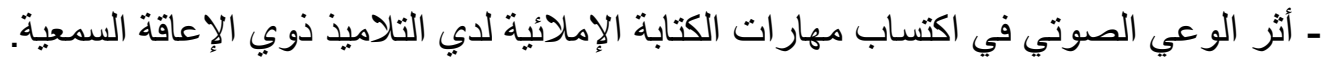


أثر برنامج قائم على الوعي الصوتي في تنمية مهارات القراعة الجهرية لاى التلاميذ ضعاف السمع بالمرحلة الإبتدائية

\section{المراجع}

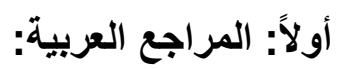

إبر اهيم، صفاء محمد محمود؛ لاشين، هدى عبد العزيز ( (1 إب): أولويات البحث التربوي في مجال المناهج إهز

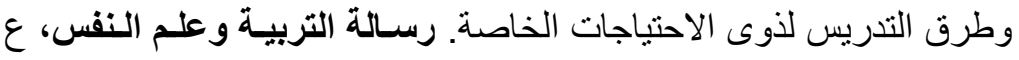

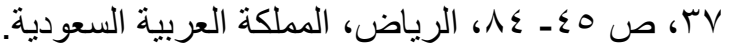

أبو حلتم، سعيد ( 0. . ץ): مهارات السمع والتخاطب والنطق المبكرة. دار أسـامة للنشـر و التوزيع و الطباعة.

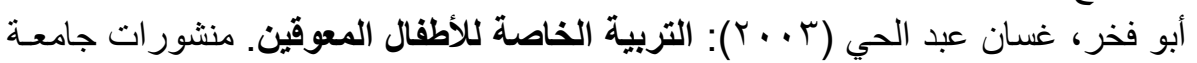

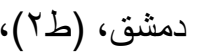

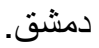

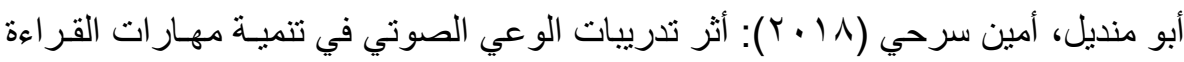
الجهرية لدى تلاميذ الديز

الصفف الرابع الأساسي مـن ذوي صـعوبات التعلم بغـرف المصــادر بغزة. رسالة ماجستير، كلية التربية، جامعة الأز هر.

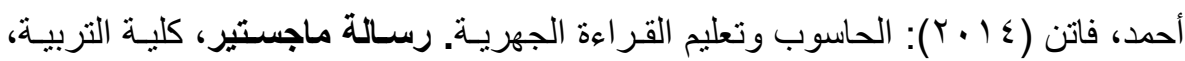

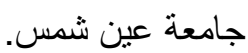

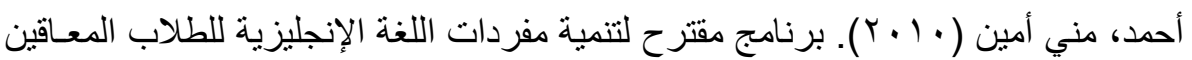

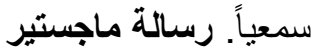

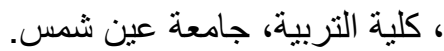

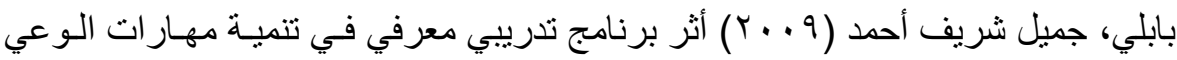

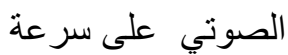

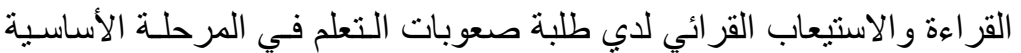

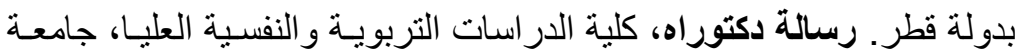

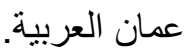

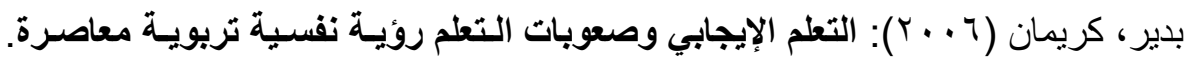

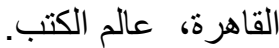

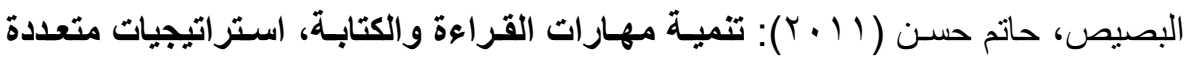
للتندريس والتقويم. دمشق، الهيئة العامة السورية للكتاب.

العدد الخامس والاربعون (الجزء الاول) ا Y.r.

(472)

مجلة كلية التربية- جامعة عين شمس 


\section{د. حنان محمد فياض}

جـاب الله، على و عبـد البـاري، مـاهر ومكـاوى، شـعبان، وسـيد، فهمي وعبـد الله، مـروة $:(Y \cdot 1 Y)$

فاعلية التدريب على أنشطة الوعي الصوتي في تتمية بعض مهار ات القراعة القاة

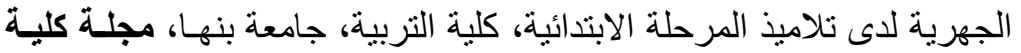

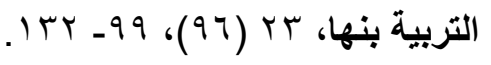

جريش، منى فرحات إير اهيم ( د.ت): فعالية التعلم التعـاوني لتحسين الـوعي الفونولـوجي

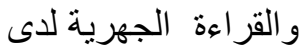

الأطفال ذوي صعوبات تعلم القر اعة (الديسليكسيا). كلية التربيـة ، جامعـة قنـاة

$$
\text { السويس. }
$$

جلاخ، مريم (1 ( • ب): در اسة المستوى الصوتي و الفونولوجي للطفل الأصم صمم متوسط

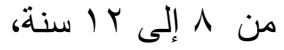

در اسات في علم الأرطوفونيا وعلم النفس العصبي، مركز البصيرة للبحوث

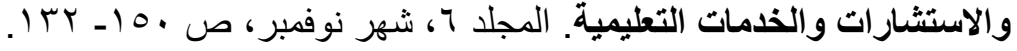

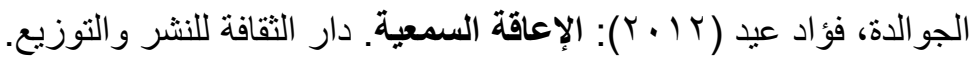

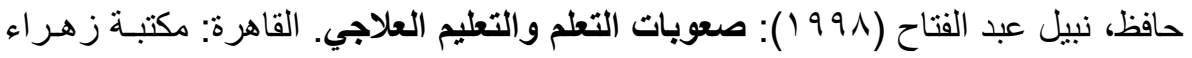
الثرق. حسانين، عو اطف محمد محمد (Y IV (Y): علاقة درجة فقد السـمع بمتغيـري مهـارة القراءة (الجهرية و الصامتة)

و العنـف المدرسـي لـدى عينـة مـن التلميـذات المعاقـات سـمعياً: دراسـة

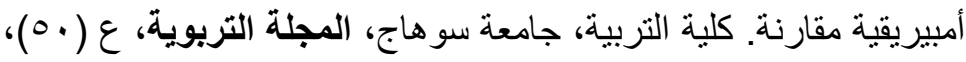

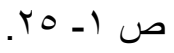

حسـن، جمـال محمــ إبـر اهيم (T ( ب). فعاليـة برنـامج للتـدخل المبكر في تتميـة الـوعي الفونولوجي

و أثره في تحسين مستوي اللغة التعبيرية لدي الأطفال ضـعاف الســع. رسـالة

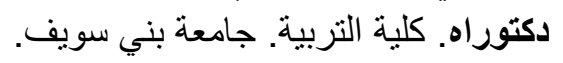

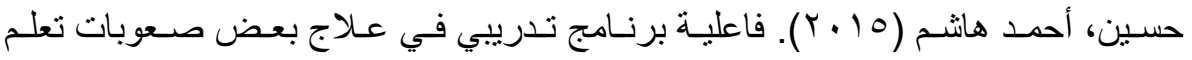
الأكاديمية

لدي الصم، رسالة ماجستير، كلية التربية، جامعة عين شمس.

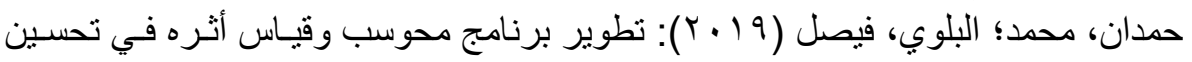

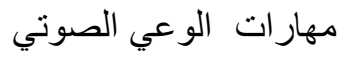

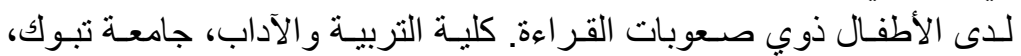

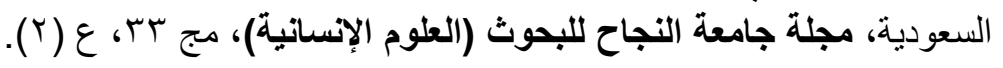

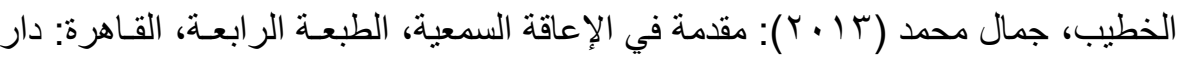


أثر برنامج قائم على الوعي الصوتي في تنمية مهارات القراعة الجهرية لاى التلاميذ ضعاف السمع بالمرحلة الإبتدائية

$$
\text { الفكر للطباعة و النشر. }
$$

مرسي، عبد العظيم شحاتة (ـ 191 ()): در اسة مقارنة لبعض مشكلات التربيـة السمعية في مصر و أمريكا. رسالة ماجستير، كلبة التربية، جامعة عين شمس.

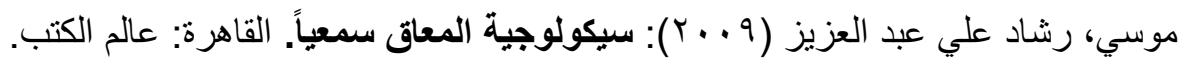

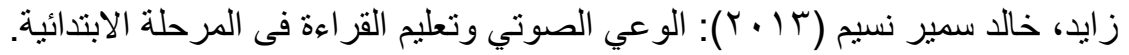
رسالة دكتور اة، كلية التربية، جامعة عين شمس.

الزريقـات، إبـر اهيم عبد الله (1) • ب): تقييم مهار ات القراءة لدى الطلبة المعاقين سمعيا في

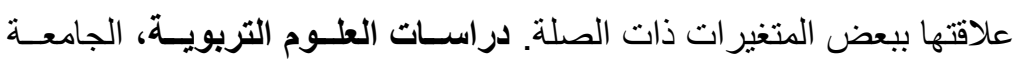
الأردن

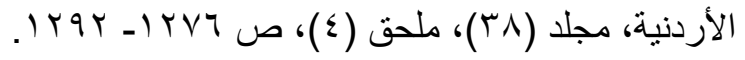

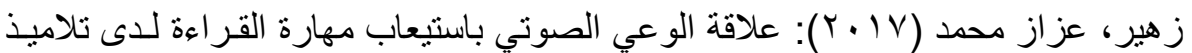
الطور الابندائي. مجلة ملئل

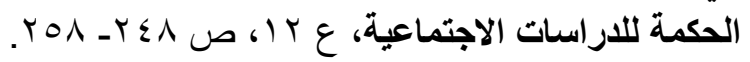

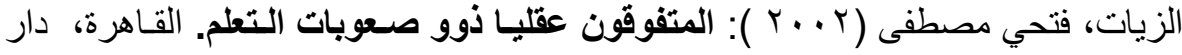

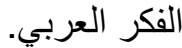

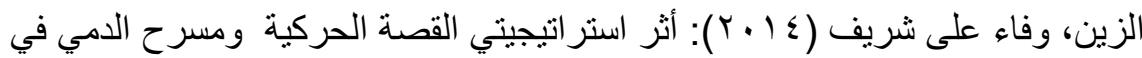

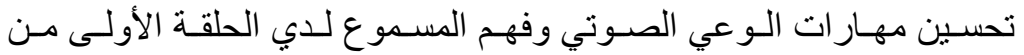

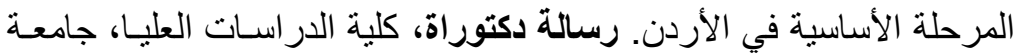

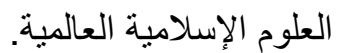

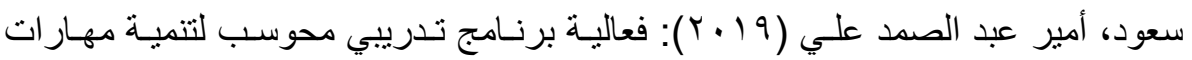

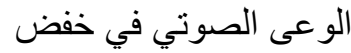

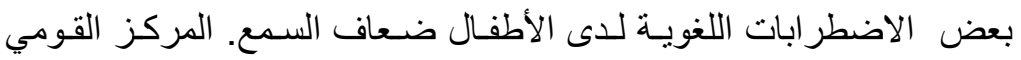

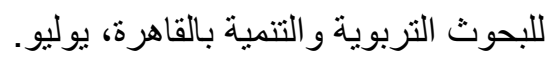
سليمان، خالد رمضان عبد الفتاح (10 • ب): فعالية برنامج لتنمية مستوى التوعي الصـوتي تحسين مهارات القراءة لدى الأطفال ذوي متلازمة داون، كلية التربية، جامعة

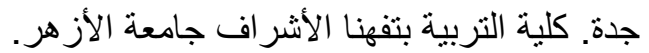

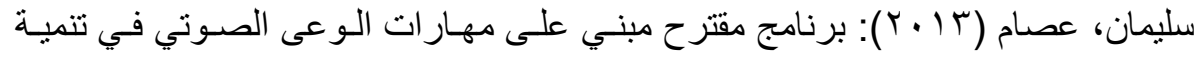




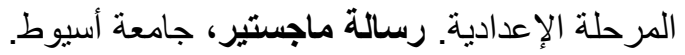

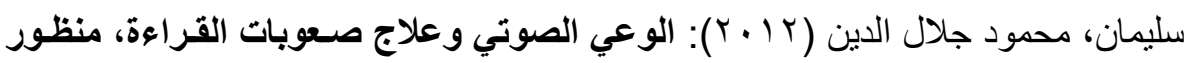
لغوي تطبيقي. عالم الكتب للنشر و التوزيع.

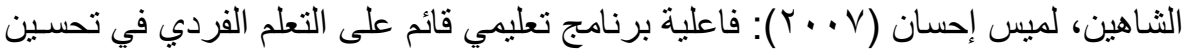
مهار ات القر اعة لدى لمين إحنان

عينة من الطلبة ضعاف السمع في معهد الصم و البكم في مدينة دمثق. رسـالة

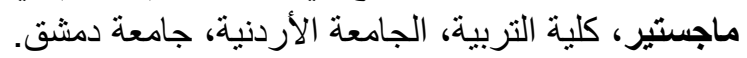

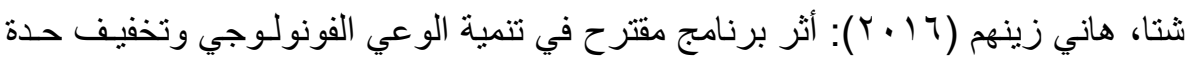

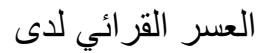

التلاميذ ذوي صعوبات التعلم بالمرحلـة الابتدائيـة. بمحافظـة رفحساء بالمملكـة

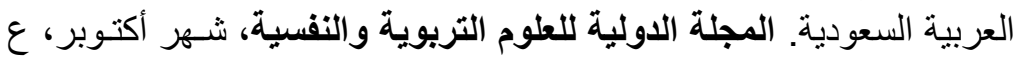

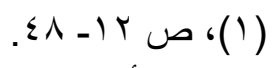

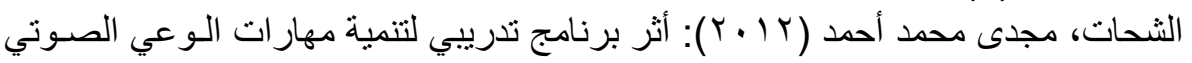
في التعرف على الكلمات مجدى مدات

لـدى التلاميـذ ذوى صـعوبات التـعلم. مركـز المعلومـات التربويـة و النفسـية

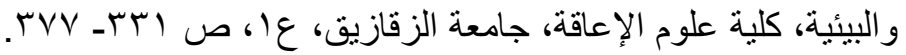

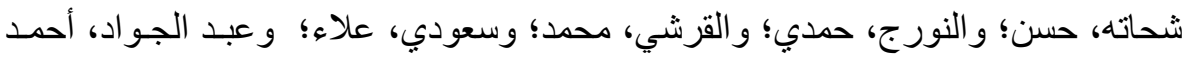

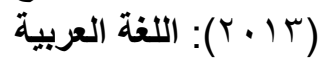

لغتي الجميلـة، الصـف الثـاني الابتــائي، فصـل دراسـي أول. وزارة التربيـة

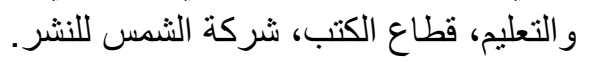

الثخص، عبد العزيز السيد والتهامي، سيد يس (9 و . . ب): اضطرابات الكلام واللغـة مـداخل

وفنيات علاجية.

القاهرة، الطبري.

الثخص، عبد العزيز السيد و الجارحي، سيد يوسف (1) (1): صعوبات التعلم الأكاديميـة التربوية والعلاجية. القاهرة: مكتبة الطبري.

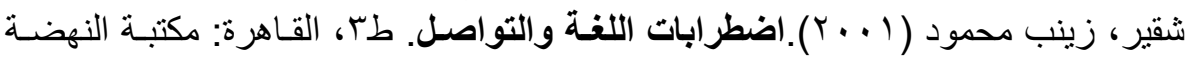
المصرية.

الثيباني، سهام عبد النبـي (): فعاليـة برنـامج تـدريبي لتنميـة الـوعي الصـوتي لـدى أطفـال المدرسة الابتدائية ذوي عيدي

صعوبات في مدينة طر ابلس بليبيا. كلية الآداب، جامعة الزاوية، ليبيا.

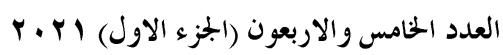

(475)

مجلة كلية التربية- جامعة عين شمس 
أثر برنامج قائم على الوعي الصوتي في تنمية مهارات القراعة الجهرية لاى التلاميذ ضعاف السمع بالمرحلة الإبتدائية

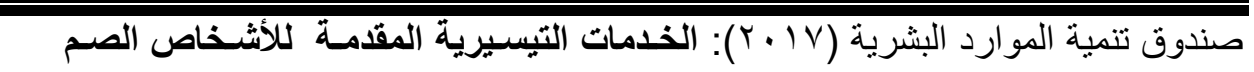

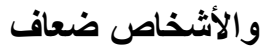

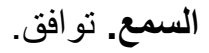

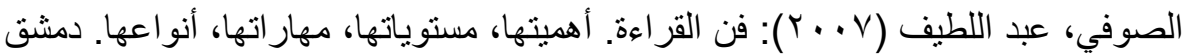

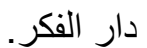
طعيمة، رشد أحمد (991 (1). الثقافة العربية الإسـلامية بين التأليف والتـدريس. القـاهرة: دار الفكر العربي.

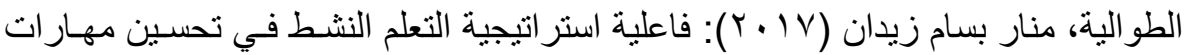

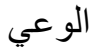

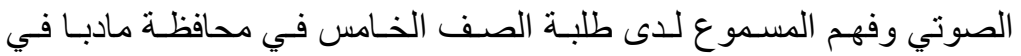

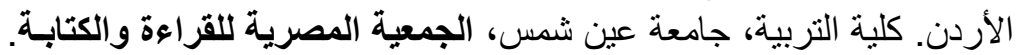

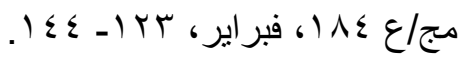

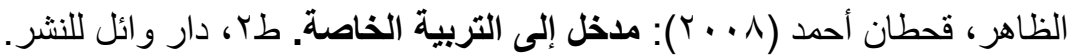

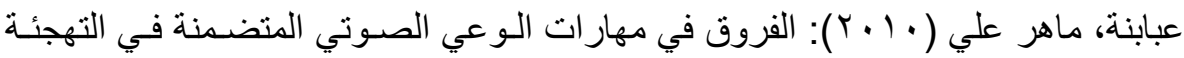
الطلبة ذوي عسر القراءة وأقرانهم في المرحلة الأساسية في الأردن. رسـالة بين

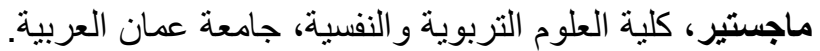

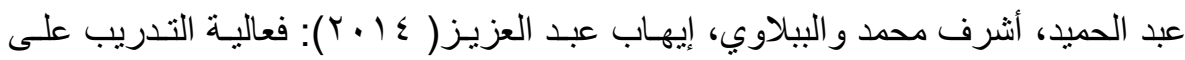
مهار ات الوعي الصوتي

في خفض بعض اضطر ابات النطق لاى الأطفال زارعي القوقعة الإلكترونية.

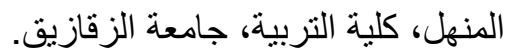

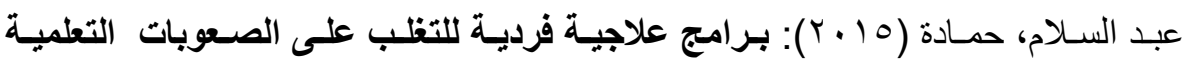
المحددة. المؤسسة البحرينية

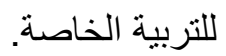

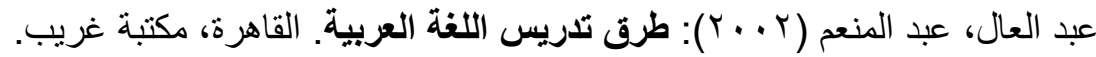

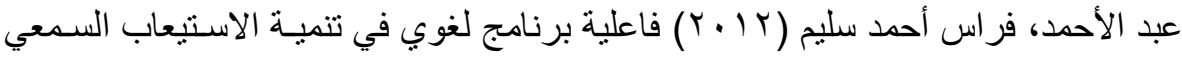
وأثره على تحسين

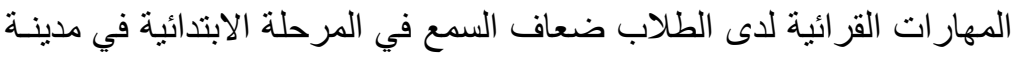

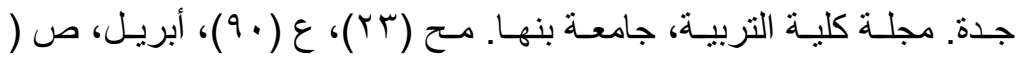
. (ror: عبد العظيم، هالة عبد القادر (1999 (19): المشكلات السلوكية للطفل الأصم. رسالة ماجستير، 


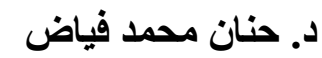

معهد الدراسات العليا

للطفولة، جامعة عين شمس.

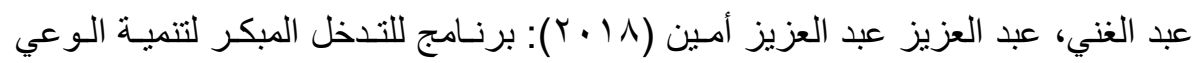
الفونولوجي لدى الأطفال

زارعي القوقعة. مجلة الإرشاد النفسي، جامعـة عين شـمس، مركز الإرشـاد

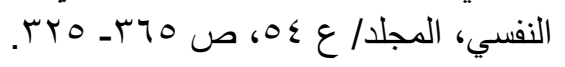

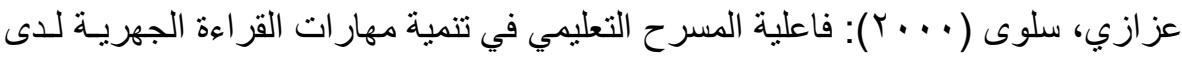

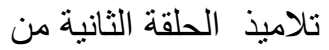

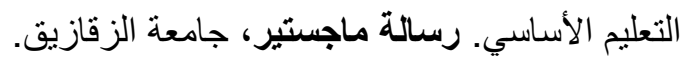

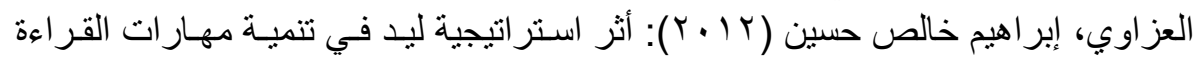

الجهرية عند تلاميذ الصف الصف الصفين

الر ابـع الابتــائي. رســالة ماجسـتير، كليـة التربيـة الأساسية، جامعـة ديـالي

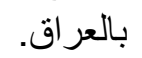

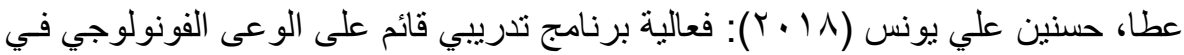
تنمية المهار ات السمعية علية

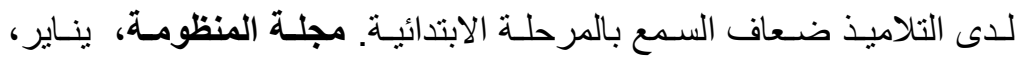

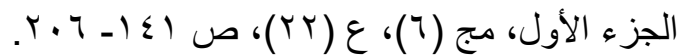

$$
\begin{aligned}
& \text { مأخوذة من الموقع الالكتروني: عالجي }
\end{aligned}
$$

article 91692 7ec4cfe3cd2188f1911a33f3393546f6.pdf (ekb.eg)

عوض، فايزة السيد؛ العو اد، عـواد بـن دخيل؛ بنـي ياسين، محمد فوزي؛ عرفـان، خالـد محمود

(9 ( ب): مداخل تعليم اللغة العربية: رؤية تحليلية. مركز الملك عبد الله بن

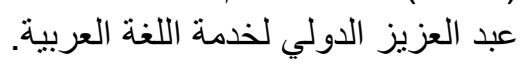

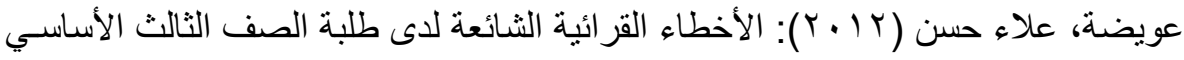
في ضوء المستويات علاء حين

المعيارية. رسالة ماجستير، كلية التربية، الجامعة الإسلامية (غزة)، فلسطين.

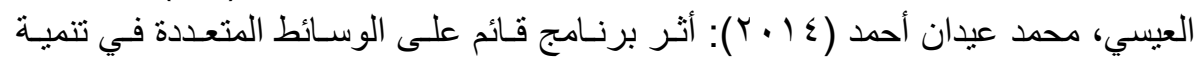

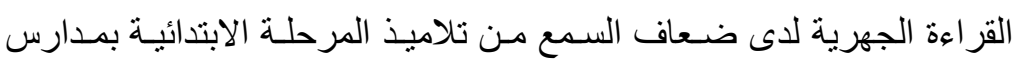

مهارة

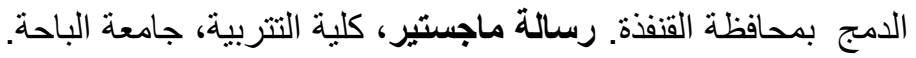

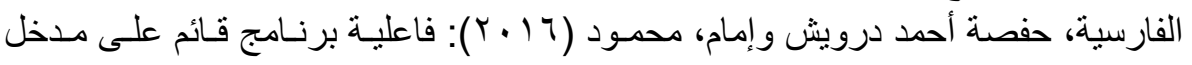

$$
\text { الوعي الصوتي في تحسين الصند }
$$

العدد الخامس والاربعون (الجزء الاول) ا ب. r.

(477)

مجلة كلية التربية- جامعة عين شمس 
أثر برنامج قائم على الوعي الصوتي في تنمية مهارات القراعة الجهرية لاى التلاميذ ضعاف السمع بالمرحلة الإبتدائية

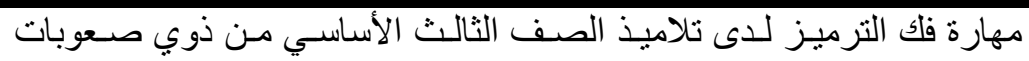
القر اءة. رسالة ماجستير، كلية التربية، جامعة السلطان قابوس.

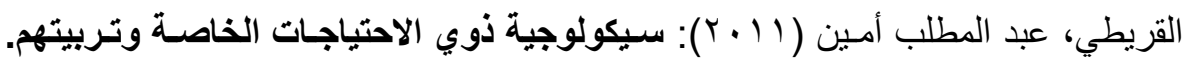

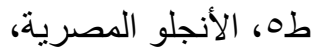

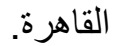

القمش، مصطفى نوري؛ المعايطة، خليل عبد الرحمن ( V . . Y): سيكولوجية الأطفال ذوى

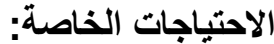
مقدمة في التربية الخاصة. دار المسيرة، عمان، الأردن.

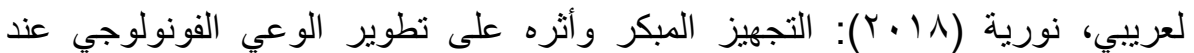

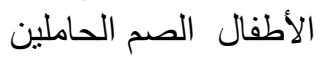
للزررع القوقعي و المجهزين كلاسيكيا. دراسة ميدانيـه، مجلة الباحث في العلوم

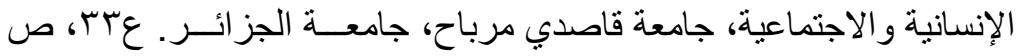

$$
\text { .7... - .019 }
$$

اللقاني، أحمد حسين؛ والقرشي، أمير (999 (19): مناهج الصـ: التخطيط والبنـاء والتنفيذ.

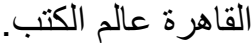

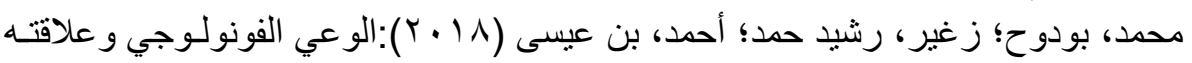
بالتعرف على الكلمة بونة

المكتوبة عند المعاقين سمعيًا، در اسة مقارنتبين ذوى الزرع القوقعي وضعاف Journal of Al-Frahedis Arts - Vol (1),323- السمع.

350

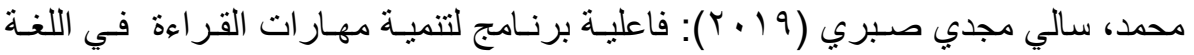
الإنجليزية لدى الأطفال ذوي الإينري الإعاقة السمعية. رسالة ماجستير، كلية التربية، جامعة عين شمس.

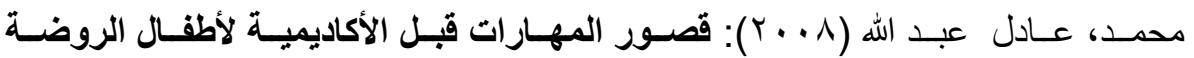
وصعوبات التعلم. طץ، القاهرة،

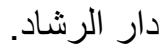

المركز القومي للامتحانـات و التقويم التربـوي (10 ـ ب): دليـل تقـويم مهــارات القـراءة

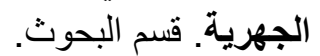

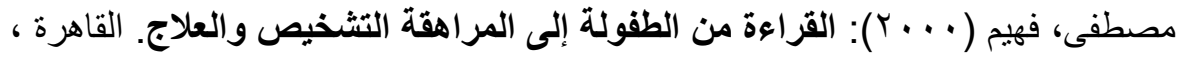

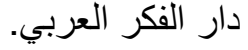


د. دنان محمد فياض

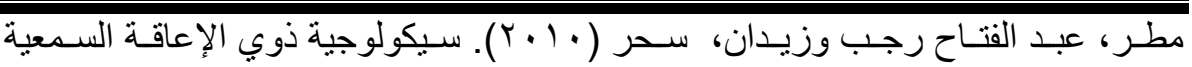
وتربيتهم. الرياض، دار النشر دور الفر

$$
\text { الدولي. }
$$

مطر، عبد الفتاح رجب؛ الجمال، رضا مسعد (T ( • (Y): فعالية التدريب السمعي في تحسين الوعى الفونولوجي موني و الفهم الكلامي لدى الأطفـال زارعي القوقعـة الإلكترونيـة. مـأخوذة

\section{Google عبد الفتاح رجب مطر - الباحث العلمي من}

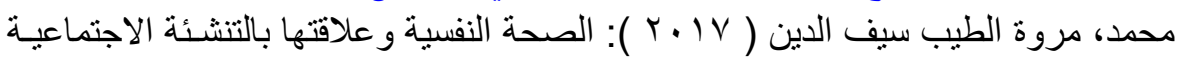

لذوي

الإعاقة السمعية مـن وجهـة نظـر الأم: در اسـة تطبيقيـة بمر اكز ذوي الإعاقـة

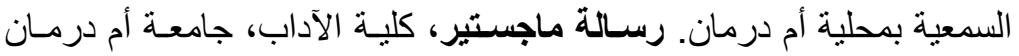

الإسلامية.

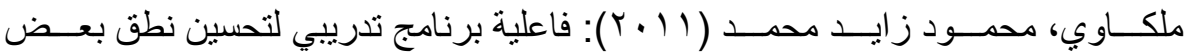

الأطفال المعوقين سمعياً إعاقة متوسطة في مرحلة رياض الأطفال. كلية اللغة

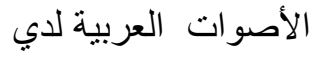

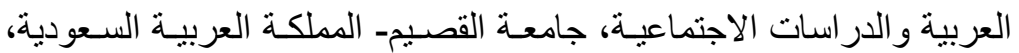

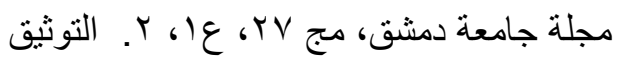

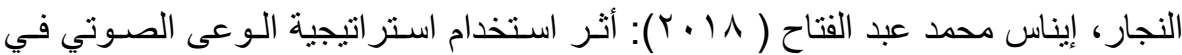
تنمية مهارة القر اعة

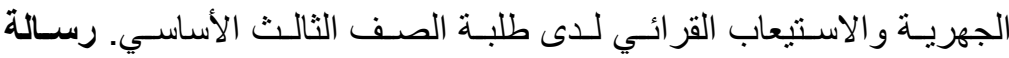

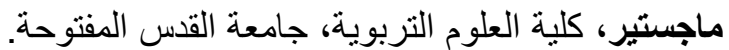

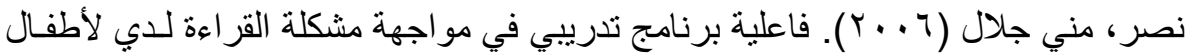
من ضعاف السمع. رسالة ماجستير. كلية التربية. جامعة عين شمس.

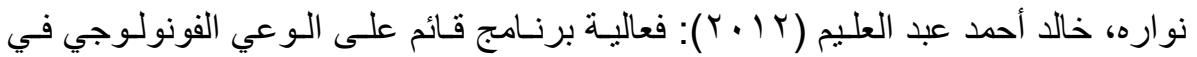
تخفيف حدة اضطر ابات

النطق لدى الأطفال المتخلفين عقلياً "القابلين للتعلم". رسـالة ماجستير، معهد

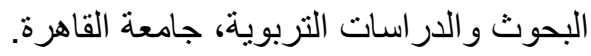

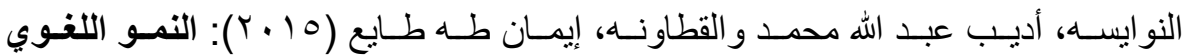
والمعرفي للطقل. مكتبة

المجتمع العربي للنشر و التوزيع، دار الإعصار العلمي للنشر والتوزيع.

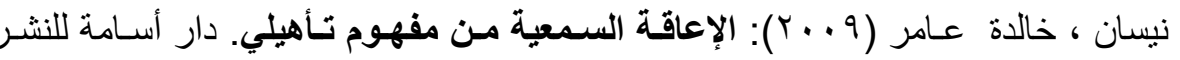

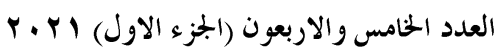

(479)

مجلة كلية التربية- جامعة عين شمس 
أثر برنامج قائم على الوعي الصوتي في تنمية مهارات القراعة الجهرية لاى التلاميذ ضعاف السمع بالمرحلة الإبتدائية

$$
\text { و التوزيع، الأردن - معنان. }
$$

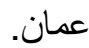

الهاثني، عبد الله مسلم؛ الخائفي، سالم خلفان؛ البوسعيدي، فاطمة يوسف؛ الموسوي، على

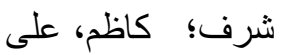

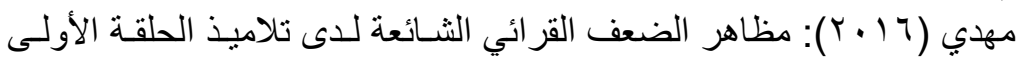

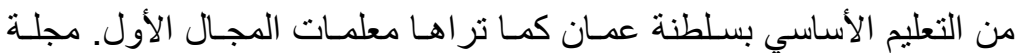

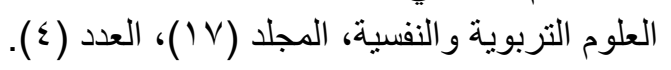

ياسين، حمدي محمد؛ شـاهين، هيام صابر ؛ حسين، عماد الدين قـاوي (دـ ت): تلنميـة اللغـة

$$
\text { وخفض عيوب النطق مئن مئن }
$$

وتحسين مهار ات الوعي الفونولوجي للأطفال المتأخرين لغويا. المنهل.

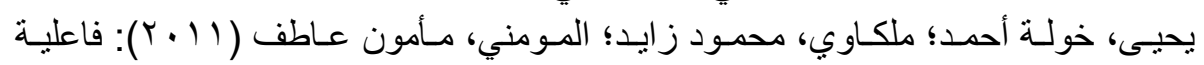
برنامج تدريبي محوسب تلبة

لتعليم مهار ات القراءة بالطريقتين التواصل الكلي و الطريقة الثـفوية لأطفـال

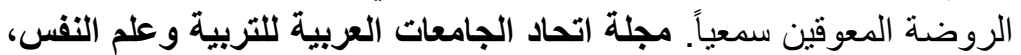

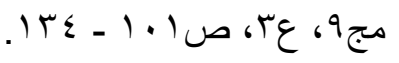


Ambrose, S. E. (2009). Phonological awareness development of preschool

children with cochlear implants (Doctoral dissertation, University of Kansas).

Camarata, S., Werfel, K., Davis, T., Hornsby, B. W., \& Bess, F. H. (2018).

Language Abilities, Phonological Awareness, Reading Skills, and Subjective Fatigue in School-Age Children with Mild to Moderate Hearing Loss. Exceptional Children, 84(4), 420-436.

Chard, D, Osbom, J, (1999): Phonics and word recognition Instruction in early

reading programs: guidelines for accessibility. Learning dishabilles research and practice, Lawrence Erlbaum association, 14 (2), 107-117.

Chen, Y.(2014). Effects of Phonological Awareness Training on Early Chinese

Reading of Children Who Are Deaf and Hard of Hearing. The Volta Review; Washington 114 (1), 85100

Cupples, L., Ching, T. Y., Crowe, K., Day, J., \& Seeto, M. (2014). Predictors of

early reading skill in 5-year-old children with hearing loss who use spoken language. Reading Research Quarterly, 49(1), 85-104.

Cynthia, C. (2004). Phonological awareness skills in kindergarten children with

and without phonological impairment. Dissertation abstracts international. Chairs: Linda J. Lombardino; Alice T. Dyson. 65-05, B, 2, 6.

Danermark, B.; Storm S., Lilian \& Borg, B. (1996): Some Characteristics of

Mainstreamed Hard of Hearing Students in Swedish University. American Annnals of the Deaf, Vol.141, pp .359- 369.

Eldik, V. T. (1994): Behavior Problems with Deaf Dutch Boys.

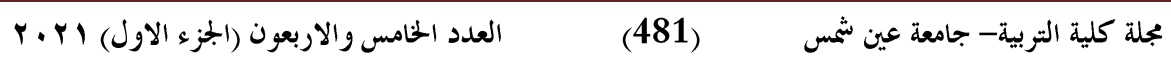


أثر برنامج قائم على الوعي الصوتي في تنمية مهارات القراعة الجهرية لاى التلاميذ ضعاف السمع بالمرحلة الإبتدائية

American Annals

of the Deaf, Vol. 139, No. 1, pp. - 399

Holmer, E., Heimann, M., \& Rudner, M. (2016). Evidence of an association

between sign language phonological awareness and word reading in deaf and hard-of-hearing children. Research in developmental disabilities, 48 (2), 145159.

Kelly, D.; Forney, J.; Fisher, S. \& Jones, M.(1993): The Challenge of Attention

Deficit Disorder in Children who are Deaf or Hard of Hearing .American Annals of the Deaf, Vol.138, No.4, p. 3

Loudemil, C (2015): An Investigation of the relationship Between Reading

comprehension and morphological awareness skills. unpublished doctor thesis, university of Arkansas for medical.

Luckner, J. L. \& McNeill, J. H. (1994) : Performance of A Group of Deaf and Hard of Hearing Students and a Comparison Group of Deaf and Hard of Hearing Students on a Series of Problem Solving Tasks. American Annals of the Deaf, Vol. 139, No. 3, pp. $371-377$.

Marschark, M.; DeBeni, R.; Polazzo, M. \& Cornoldi, C. (1993): Deaf

and Hard of Hearing Adolescents Memory for Concrete and Abstract Prose. American Annals of the Deaf, Vol. 138, No. 1, pp. 31 - 39.

Mastropieri, M \& Scurggs, T (2007). The inclusive Classroom: Strategies

for effective instruction. New Jercy : Pearson Education.

Messier, J \& Jackson, C. (2013). A Comparison of Phonemic and Phonological 
Awareness in Educators Working with Children Who Are d/Deaf or Hard of Hearing. American Annals of the Deaf, 158 (5), 522-538.

Michel, H. (2007). The neurological basis of developmental dyslexia: an overview

and working hypothesis. France: Cognitive Laboratory, Department of Neurology.

Miller, M; Lederberg, R \& Easterbrooks , S. (2013): Phonological Awareness:

explicit instruction for young deaf and hard -of- hearing children. Journal of deaf Studies and deaf Education, 18, (2), 206.

Mohammed,B. Hamed,R. Ahmed ,B.(2018): Phonological awareness and its

relation to the recognition of the written word for the hearing impaired. Journal of Al-Frahedis Arts, Vol (1), N (34), P323- 350.

Narr, R. F. (2008). Phonological awareness and decoding in deaf/ hard - of -

hearing students who use Visual Phonics. Journal. of deaf studies and deaf education, 13(3), 405 - 416.

Paul, P. V., Falk, J. L., Jahromi, L. B., \& Ahn, S. (2017). Wang, Y. Predictors of

English reading comprehension for children who are $\mathrm{d} /$ Deaf or hard of hearing. Journal of Developmental and Physical Disabilities, 29(1), 35-54

Schmidt, j ; rozendal, S.\& greenman, G. (2002): Reading instruction in the

inclusion classroom remedial special and education. $\mathrm{V}$ 25, (3), 130- 145.

Stephanie,c (2008): Accommodations use for statewide standardized Assessment:

prevalence and recommendations for students who are deaf or hard of hearing. Journal of Deaf Studies and deaf Education, $\mathrm{V} 13, \mathrm{~N} 1, \quad \mathrm{P} \quad 55-96$. 
أثر برنامج قائم على الوعي الصوتي في تنمية مهارات القراعة الجهرية لاى التلاميذ ضعاف السمع بالمرحلة الإبتدائية

Torgeson, J. (2001). Assessment of phonological awareness Designed especially

for the Learning to Read: Beginning Reading Instruction CD-ROM. Interactive Training Media, Inc

Trieman, R.(1991). Phonological awareness and its roles in learning to read and

spell. In D. Sqwyer and (tds), Phonological awareness in reading: the evolution of current perspective. New York: Sping verlag.

Tsai, Y. (2009). The impact of dialogic reading. Facilitating language acquisition

of young children with hearing impairments in Taiwan, $\boldsymbol{P h D}$ of Philosophy, The Pennsylvania State University the Graduate School College of Education.

Yssldyke, J.; Algozzin B. (2007): Special Education: A Practical Approach. for

Teachers. New Jercey, Houghton Mifflin 